NBER WORKING PAPER SERIES

\title{
RISK PROTECTION, SERVICE USE, AND HEALTH OUTCOMES UNDER COLOMBIA'S HEALTH INSURANCE PROGRAM FOR THE POOR
}

\author{
Grant Miller \\ Diana M. Pinto \\ Marcos Vera-Hernández \\ Working Paper 15456 \\ http://www.nber.org/papers/w15456
}

\author{
NATIONAL BUREAU OF ECONOMIC RESEARCH \\ 1050 Massachusetts Avenue \\ Cambridge, MA 02138 \\ October 2009
}

This paper previously circulated as "High-Powered Incentives in Developing Country Health Insurance: Evidence from Colombia's Régimen Subsidiado." We are grateful to Orazio Attanasio, Jay Bhattacharya, Adriana Camacho, Pedro Carneiro, Ken Chay, Will Dow, Liran Einav, Alan Garber, Ursula Giedion, Mike Grossman, Ted Joyce, Robert Kaestner, Carlos Medina, Costas Meghir, Imran Rasul, anonymous referees, and numerous seminar participants for helpful suggestions; to Luis Carlos Ortiz, Renata Pardo, Licerole Ruiz, Sandra Sterling, and Elisa Torrenegra for discussions about the health policy context in Colombia; to the Departamento Nacional de Planeación (DNP), the Departamento Administrativo Nacional de Estadística (DANE), and Profamilia for data and SISBEN index information; to Adriana Ruiz for GIS assistance; and to the Economic and Social Research Council (RES-167-25-0124), Economic and Social Research Council-NCRM (ES/I03685X/1), Advanced ERC Grant (249612), the Inter-American Development Bank, the National Institute of Child Health and Human Development (K01 HD053504), and the Stanford Center on the Demography and Economics of Health and Aging for financial support. Soledad Giardili, Carolina Mejia, Nicole Smith, and Julieta Trias provided excellent research assistance. We alone are responsible for the views in this paper as well as all errors. The views expressed herein are those of the author(s) and do not necessarily reflect the views of the National Bureau of Economic Research.

NBER working papers are circulated for discussion and comment purposes. They have not been peerreviewed or been subject to the review by the NBER Board of Directors that accompanies official NBER publications.

(C) 2009 by Grant Miller, Diana M. Pinto, and Marcos Vera-Hernández. All rights reserved. Short sections of text, not to exceed two paragraphs, may be quoted without explicit permission provided that full credit, including $(\mathcal{C}$ notice, is given to the source. 
Risk Protection, Service Use, and Health Outcomes Under Colombia's Health Insurance Program for the Poor

Grant Miller, Diana M. Pinto, and Marcos Vera-Hernández

NBER Working Paper No. 15456

October 2009, Revised December 2012

JEL No. I10,O10

\begin{abstract}
Unexpected medical care spending imposes considerable financial risk on developing country households. Based on managed care models of health insurance in wealthy countries, Colombia's Régimen Subsidiado is a publicly financed insurance program targeted to the poor, aiming both to provide risk protection and to promote allocative efficiency in the use of medical care. Using a "fuzzy" regression discontinuity design, we find that the program has shielded the poor from some financial risk while increasing the use of traditionally under-utilized preventive services - with measurable health gains.
\end{abstract}

Grant Miller

CHP/PCOR

Stanford University

117 Encina Commons

Stanford, CA 94305-6019

and NBER

ngmiller@stanford.edu

Diana M. Pinto

Department of Clinical Epidemiology

and Biostatistics

Faculty of Medicine

Pontificia Universidad Javeriana

7th Avenue, \#40-62, Second Floor

Bogotá, Colombia

dmpinto@gmail.com
Marcos Vera-Hernández

University College London

Department of Economics

Gower St.

London WC1E 6BT

United Kingdom

m.vera@ucl.ac.uk 


\section{Introduction}

In developing countries, the inability to smooth consumption directly reduces welfare and leads to informal risk management strategies that stifle productive activity (Paxson 1993, Townsend 1994, Morduch 1995). Because unexpected illness is a leading source of economic risk, the expansion of health insurance is therefore a public policy priority in many parts of the developing world (Gertler and Gruber 2002, GTZ, WHO, and ILO 2005, WHO 2010, Mohanan 2012). ${ }^{1}$ Such initiatives are often large, centrally-planned programs operated exclusively through the public sector - and they focus primarily on reducing the out-of-pocket price of medical care. $^{2}$

An early exception is Colombia’s Régimen Subsidiado (or “Subsidized Regime,” henceforth “SR”). Introduced in 1993, the SR is a pluralistic, publicly-financed health insurance program targeted to the poor. ${ }^{3}$ Colombians meeting a proxy means-test (determined by the Sistema de Identificación de Beneficiarios, or SISBEN) are fully-subsidized to purchase insurance from private, government-approved insurers. In contrast to the classical 'managed competition' model of insurance (Enthoven 1978a and 1978b), participating insurers must offer standardized benefits packages and accept standardized premiums. Insurers can, however, form restrictive medical care networks, deny reimbursement for services deemed 'unnecessary,' and pay health care providers in ways that encourage higher quality and lower cost medical care

\footnotetext{
${ }^{1}$ For example, one study finds that 5\% of Latin American households spend 40\% or more of 'non-subsistence' income on medical care each year (Xu et al. 2003). As Gertler and Gruber (2002) note, there are two major costs of illness: medical care costs and reduced labor income. Health insurance (our focus) addresses the former, while disability insurance addresses the latter.

${ }^{2}$ See Abel-Smith (1992); Dow, Gertler, Schoeni, Strauss, and Thomas (1997); WHO (2000); WHO Commission on Macroeconomics and Health (2001); Gertler and Solon (2002); Dow, Gonzalez, Rosero-Bixby (2003); Dow and Schmeer (2003); Gakidou et al. (2006); Pauly, Zweifel, Scheffler, Preker, and Bassett (2006); Hughes and Leethongdee (2007); Wagstaff (2007); Wagstaff and Yu (2007); O’Donnell et al. (2008); Pauly, Blavin, and Meghan (2008); and Gruber, Hendren, and Townsend (2012).

${ }^{3}$ According to Article 153 of Law 100 (authorizing the creation of the SR), one of the SR's guiding principles is Proteccion Integral: "The System of Social Security in health will provide health care to the population in: education, information, health promotion and prevention, diagnostic, treatment and rehabilitation in quantity and quality according to the Plan Obligatorio de Salud."
} 
(through capitated payment contracts, for example - fixed payments per enrollee per month).

Overall, Colombia's SR shares features of managed care models of health insurance that emphasize cost-containment and allocative efficiency traditionally found only in wealthy countries. It therefore represents important early experience in a markedly different institutional environment.

This paper studies the impact of the SR on financial risk protection, service use, and health outcomes among Colombia’s poor. Program eligibility is supposed to be determined according to a discrete threshold in the continuous SISBEN index, so in principle we could use a regression discontinuity design to do so. Because SISBEN scores are manipulated in practice (BDO and CCRP 2000, DNP 2001, 2003a, and 2003b, Fresneda 2003, Camacho and Conover 2011), we instead use underlying index components collected through independent household surveys to generate our own (un-manipulated) SISBEN score calculations. We then instrument for SR enrollment with our re-constructed eligibility measure (Hahn, Todd, and Van der Klaauw 2001). In general, our estimates are robust across a variety of parametric and non-parametric specifications.

Despite our strategy for addressing manipulation of eligibility, our approach has limitations. First, because we use household surveys to implement a "fuzzy" regression discontinuity design, our samples are relatively small. Second, we measure SISBEN index components after official SISBEN classification occurred, presumably resulting in a degree of measurement error. Third, due to financial shortfalls, many of Colombia's municipios (hereafter, "counties") used eligibility thresholds that fell short of the official one. Following Chay, McEwan, and Urquiola (2005), we therefore estimate and use county-specific thresholds. These 
limitations introduce noise into the regression discontinuity design and generally bias us against finding behavioral responses to the SR.

We first find evidence that by the mid-2000s, the SR succeeded in protecting poor Colombians from financial risk associated with the medical costs of unexpected illness. In particular, SR enrollment appears to have reduced the variability of out-of-pocket spending for inpatient care. Despite this reduction in risk, however, we observe little evidence of meaningful portfolio choice effects (changes in the composition of household assets, human capital investments, or household consumption), perhaps because the SR falls short of providing full insurance.

Our results also suggest that SR enrollment is associated with large increases in the use of traditionally under-utilized preventive services - some of which nearly doubled. Moreover, we find evidence of health improvement under the SR as well - specifically, gains along margins sensitive to the increases in preventive care that we observe. There is more mixed evidence of changes in the use of curative services (although theoretical predictions about the use of curative care are ambiguous).

We conclude by discussing the underlying behavioral mechanisms that may explain our results. Because the SR is complex and multi-faceted, it is important to note that we cannot draw firm inferences about them; we emphasize this as an important direction for future research. Overall, we highlight two mechanisms that we suspect are important: high-powered supply-side incentives and the possibility that enrollees receive care from higher-quality private sector facilities. 


\section{Background and Policy Context}

\subsection{Public Sector Health Insurance for Colombia’s Poor Prior to the Reform}

Prior to the introduction of the SR in 1993, roughly 25\% of Colombians (a subset of those with formal sector jobs) had any form of explicit health insurance (Pinto 2008). However, Colombians lacking formal insurance also had a degree of implicit insurance provided through the public sector. Specifically, they could receive medical care from public sector hospitals and clinics for a fraction of the full cost of their services; out-of-pocket payments were generally progressive and loosely based on socio-economic status. Public sector facilities, in turn, covered their losses with direct transfers from national and local governments, and health care professionals were typically paid fixed salaries that did not reward productivity. Thus, poor Colombians effectively had a degree of implicit health insurance coupled with inefficient provider incentives - and the reform that we study aimed to expand coverage while improving efficiency.

\section{$\underline{2.2 \text { Overview of Colombia’s Subsidized Health Insurance Regime for the Poor }}$}

Under Law 100 in 1993, Colombia introduced the SR, a novel form of publicly-financed health insurance for the poor (Gwatkin et al. 2005, Escobar 2005). Primarily through SR expansion, formal health insurance coverage in Colombia grew from about $25 \%$ of the population in 1993 to $80 \%$ in 2007 (CENDEX 2008). The SR is organized as a variant of the classical ‘managed competition’ model (Enthoven 1978a and 1978b). Beneficiaries are fully subsidized to purchase health insurance from competing health plans. During our study period (the mid-2000s), subsidies were financed by a combination of public resources including payroll taxes and national and local general revenue. These resources are transferred to county governments, which in turn are responsible for eligibility determination, enrollment, and 
contracting with health plans. This role of local government has important implications for our empirical analysis.

Health plans charge county health authorities a government-regulated premium per enrollee and offer a standardized package of benefits (see Appendix 1 for the details of these benefits). ${ }^{4}$ Participating health plans then act as group purchasers of health services for their enrollees by contracting with a network of health facilities and clinicians. Because premiums and benefit packages are standardized by law (unlike the classical 'managed competition' model), health plans compete for enrollees on the basis of provider networks and service quality. In practice, however, very few cities had more than one insurer during the years that we study. Insurers' ability to contract with health care providers (hospitals and medical groups) for more efficient service provision is a central innovation of the SR. Insurers receive premiums (fixed payments per enrollee per unit time) for all covered services, giving them strong incentives to constrain total spending. Insurers then (partially) transmit these incentives to provider organizations through capitated payment contracts, and they have the authority to deny reimbursement for services deemed inefficient. ${ }^{5}$

In the next section we describe the major demand- and supply-side incentive changes under the SR, and Section 3 then provides predictions based on them for health service use, outof-pocket spending on medical care, and health outcomes.

\footnotetext{
${ }^{4}$ During our study period, the benefits package of the SR (Plan Obligatorio de Salud Subsidiado) emphasized coverage for primary and basic outpatient services, drugs, and some catastrophic care. There was limited coverage for specialist services, and there were substantial gaps in coverage for hospital care.

${ }^{5}$ Provider organizations, in turn, must transmit the incentives they face to individual clinicians whom they employ. Our interviews with stakeholders in the Colombian health care system suggest that organizations solve this agency problem through non-financial rather than payment-based incentives (systematic data on organizational incentives and clinician contracts is unfortunately unavailable).
} 


\subsection{Changes in Demand- and Supply-Side Incentives under the SR}

There were important changes in both demand- and supply-side incentives with the introduction of the SR. On the demand-side, out-of-pocket prices for covered curative services are $10 \%$ of the full price (as opposed to $30 \%$ for poor uninsured Colombians). ${ }^{6}$ Moreover, total out-of-pocket spending per episode of illness each year is capped at half of the monthly minimum wage for SR beneficiaries - while the same cap is six times as large for uninsured patients (Decreto 2357 and Acuerdo 260 of the Consejo Nacional de Seguridad Social en Salud). Notably, preventive services are essentially free regardless of insurance status.

On the supply-side, changes in provider payment contracts created substantially different incentives for the provision of health services. Specifically, there are two types of contracts between insurers and provider organizations under the SR: capitated primary care contracts and fee-for-service specialty care contracts. For primary care, insurers pay providers fixed amounts per month for all services used by enrollees (“capitation”). These contracts create strong incentives for providers to constrain total spending on primary care and have important implications for both preventive and curative health care (as discussed in the next section). Importantly, promotion of preventive care can be a central means of reducing total expenditures. ${ }^{7}$

For specialty care, insurers generally pay providers a pre-determined fee for each covered service that they supply (i.e., on a "fee-for-service" basis). These contracts encourage the provision of all reimbursable services (both efficient and inefficient). However, SR insurers also

\footnotetext{
${ }^{6}$ The Colombian Ministry of Social Protection maintains a fee schedule (SOAT) regulating out-of-pocket prices. For example, the full price for a physician consultation was 17,300 pesos in 2007 and 18,460 pesos in 2008 (approximately US \$10). Medical facility social workers assess uninsured patients' “ability to pay” and may charge them sliding scale out-of-pocket fees (greater than $10 \%$ of the full price) on a case-by-case basis.

${ }^{7}$ Many medical professionals believe that increasing prevention reduces overall medical spending - whether or not this is true depends on prices, the health production function, and competing risks. Cohen, Neumann and Weinstein (2008) find that $20 \%$ of preventive measure in the US are cost saving.
} 
have the authority to deny reimbursement on a case-by-case basis for inefficient specialty care (termed “utilization review”), allowing them to limit wasteful service use. ${ }^{8}$

\subsection{Eligibility for the SR}

Eligibility for the SR is determined using a poverty-targeting index called SISBEN (or Sistema de Identificación de Beneficiarios). The original SISBEN index consisted of fourteen components measuring different aspects of household well-being (such as housing material, access to public utilities, ownership of durable assets, demographic composition, educational attainment, and labor force participation - for a complete description, see Appendix 2). ${ }^{9}$ On each dimension, households are classified according to mutually exclusive, collectively exhaustive categories with varying weights assigned to each category; these weights vary between urban and rural areas. A household's SISBEN score is then calculated by summing points across components. Possible scores range from 0 to 100 (with 0 being the most impoverished) and are divided into six strata. Households scoring in SISBEN strata 1 and 2 (the lowest strata) are eligible for the SR (below 48 in urban areas, below 31 in rural areas). ${ }^{10}$

\subsection{Eligibility and Enrollment in Practice}

Although eligibility for the SR increases the likelihood of enrollment, neither one necessarily implies the other for at least three reasons: misclassification or manipulation of

\footnotetext{
${ }^{8}$ Utilization review does little to promote services traditionally used sub-optimally.

${ }^{9}$ Eligibility also varies within households because certain demographic groups (including pregnant women and young children) are prioritized for enrollment.

${ }^{10}$ SISBEN eligibility shifts abruptly at each county's cabecera boundary, an administrative demarcation formally distinguishing urban and rural parts of each county and loosely corresponding to the fringe of public utility infrastructure. Distinct urban and rural SISBEN scales are applied to households on corresponding sides of the boundary, differing both in component parts and in the weighting of response categories for each component. We implemented a research design exploiting these urban/rural index differences, but inconsistent application of the rural index and data limitations prevent us from drawing meaningful conclusions from it. In this paper we therefore focus on urban eligibility.
} 
SISBEN scores, shortfalls in local government revenue, and enrollment that preceded SISBEN enumeration. ${ }^{11}$

First, both local governments and households have incentives to manipulate SISBEN scores. Local governments receive fixed transfers from the national government for each resident they enroll, creating incentives to maximize enrollment. The selective enrollment of key constituents can also provide political benefits (Camacho and Conover 2011). Households prefer enrollment over "uninsurance" as well because co-payments are lower for SR beneficiaries than for those lacking formal insurance. Consistent with both types of incentives, there is evidence of considerable SISBEN score manipulation between 1997 and 2003 (Camacho and Conover 2011). ${ }^{12}$

Second, most local governments lack sufficient revenue to finance the enrollment of all eligible residents. According to law, those with lower SISBEN scores and those belonging to specific targeted groups (such as children under five and pregnant women) are therefore prioritized for enrollment. ${ }^{13}$ This means that many counties use de facto eligibility thresholds that fall below the uniform national threshold.

Third, some counties began enrolling residents in the SR before all of their residents had been classified using SISBEN. These counties instead used other means-test criteria such as residents’ estrato, a neighbourhood-level measure of socio-economic status used to establish electricity prices paid by local households.

\footnotetext{
${ }^{11}$ Administrative mistakes in the enrollment process are also important.

${ }^{12}$ Using results from the 2005 population census, the Colombian newspaper El Tiempo reports that there are more SR enrollees than residents in some counties (El Tiempo, October 26, 2006). Camacho and Conover (2011) show that the distribution of official SISBEN scores exhibits both large leftward shifts in density over time and the formation of a mass point just to the left of the national eligibility threshold in urban areas. Neither are present in Colombian household surveys. The former suggests misrepresentation by households, while the latter suggests misrepresentation by enumerators or officials.

${ }^{13}$ The laws formalizing this prioritization are Acuerdos 244 and 253 of the Consejo Nacional de Seguridad Social en Salud. This prioritization also means that although SISBEN scores are calculated at the level of family

"nucleus," individuals within families can vary in enrollment status; we observe this in our household survey data.
} 
In general, these realities of the program's implementation have two broad implications for our empirical analyses (which we discuss in greater detail in Section 4.2). One is the necessity of an empirical strategy that addresses manipulation of SISBEN scores. The other is that de facto county threshold must be estimated (because they are not officially reported).

\subsection{Previous Studies}

Several previous empirical papers have studied Colombia’s SR as well (see Giedion and Uribe (2009) for a comprehensive review). Trujillo et al. (2005) use propensity score matching to compare SR enrollees to observationally similar uninsured Colombians, finding that the SR is associated with greater medical care use. Giedion et al. (2009) also use propensity score matching and find that SR enrollment is associated with more visits to health care providers, higher vaccination coverage rates, and fewer reports of not seeking medical care for financial reasons. Gaviria, Medina, and Mejía (2007) instrument for SR enrollment using length of time a household head lived in his/her current place of residence and report that SR enrollment is associated with better self-reported health, more preventive and curative outpatient care, and fewer hospitalizations. Finally, matching official SISBEN score data with birth records, Camacho and Conover (2008) use a regression discontinuity design in two samples: a county lacking clear evidence of manipulation and selected counties observed shortly after SR implementation. They find that SR enrollment is associated with increased birth weight and better APGAR scores but not antenatal care use, medical supervision of deliveries, or probability of hospital delivery. Relative to previous studies of the SR, our paper employs a different strategy for addressing manipulation of program eligibility, uses an approach that disentangles 
the role of the SR from other public programs using SISBEN, and studies a broader range of behavioral responses to health insurance. ${ }^{14}$

\section{Empirical Predictions on the Interaction of Supply- and Demand-Side Incentives}

Although we emphasize the centrality of changes in supply-side incentives under the SR, out-of-pocket prices for covered services also fell. This section therefore considers the joint effect of supply- and demand-side changes in formulating predictions about changes in risk protection, the use of preventive and curative services, and health outcomes. Section 5 then provides empirical evidence on each.

Risk Protection and Out-of-Pocket Medical Spending. Protecting households against medical care costs associated with unexpected illness is a central objective of health insurance. As Appendix 1 shows, the SR covers many of the most expensive services including trauma care, dialysis, and major joint replacement (hips and knees, for example). It also caps total outof-pocket spending per episode of illness each year at half of the monthly minimum wage. The SR should therefore reduce the variability of out-of-pocket medical spending. Assuming that the price elasticity of demand for medical care is less than one, the SR should also reduce total outof-pocket spending for medical care.

Preventive Health Services. Most preventive services in Colombia are free regardless of insurance status (i.e., free both for SR enrollees and the uninsured), so the main difference in incentives for preventive care originate on the supply-side. Primary care providers are paid on a capitated basis, so they have strong incentives to limit total primary care spending. Increasing

\footnotetext{
${ }^{14}$ See Card, Dobkin, and Maestas (2008), Card, Dobkin, and Maestas (2009), Chandra, Gruber, and McKnight (2010a), and Anderson, Dobkin, and Gross (2012) for recent regression discontinuity studies of health insurance in the United States. For recent work on the United States using other methodologies, see Doyle (2005), Dafny and Gruber (2005), Finkelstein (2007), Finkelstein and McKnight (2008), Kolstad and Kowalski (2010), Chandra, Gruber, and McKnight (2010b), and Kowalski (2011).
} 
preventive service use can reduce the need for more costly curative care - and can therefore be cost-saving - so capitated primary care incentives are likely to increase preventive care use. ${ }^{15}$

An opposing force at work is ex ante moral hazard: SR enrollees may have weaker incentives to use preventive services because they pay less for curative care (Nordquist and $\mathrm{Wu}$ 1976, Phelps 1978). Although we fail to find evidence of ex ante moral hazard (as shown in Section 5.5) and there is little evidence of it in other studies (Kenkel 2000), our preventive care estimates reflect the net effect of these forces. ${ }^{16}$ Because preventive services generate important positive externalities (both pecuniary and infectious disease-related), increases in their use presumably improve welfare. ${ }^{17}$

Curative Medical Care. Three changes under the SR are likely to influence the use of curative medical care: reductions in out-of-pocket prices, increases in the use of preventive services, and supply-side incentives for limiting total medical spending. First, for negative price elasticities of demand, reductions in out-of-pocket prices will increase the use of curative care. This increase is inefficient under standard assumptions (ex post moral hazard); however, curative care in developing countries may produce positive externalities, and there may also be important credit constraints. Second, any increases in preventive service use may reduce the use of curative care (an efficient result). Third, both capitation and utilization review produce incentives for providers to limit the use of curative medical care. Some reductions may be efficient (counterbalancing demand-side incentives leading to ex post moral hazard) while others

\footnotetext{
${ }^{15}$ One randomized controlled trial in the US and another in the UK show that capitation increases preventive service use (Manning et al. 1984, Lennon et al. 1990). This finding is also consistent with the evidence from observational studies summarized by Miller and Luft (1994) and more recent research by Keenan et al. (2009).

${ }^{16}$ The RAND Health Insurance Experiment reports no sizeable or significant effect of insurance coverage on health behaviors (smoking, drinking, and exercise) (Newhouse and the Insurance Experiment Group 1993). Medicare coverage has also been reported not to increase unhealthy behaviors (Dave and Kaestner 2006).

${ }^{17}$ Popular conditional cash transfer programs - including the Familias en Acción program in Colombia - aim to increase the use of preventive services even though they are otherwise available for free. At least eleven developing countries have introduced such conditional cash transfer programs (Fiszbein and Schady 2009).
} 
may be inefficient (leading to “stinting” - see for example Ellis and McGuire (1990), Holmstrom and Milgrom (1991), Ma and McGuire (1997), and McGuire (2000)). Predictions about changes in curative care under the SR as well as their welfare implications are therefore ambiguous.

Health Outcomes. Both preventive and curative services are inputs into health production. If at least one of these two types of care increases and neither of them decreases, health should presumably improve to some degree. Alternatively, the prediction is ambiguous if one type increases and the other decreases. In our empirical analyses, we are able to examine the prevalence of infectious diseases common among children (diarrhea, cough and fever) as well as the number of days lost to illness.

\section{Data and Empirical Strategy}

\section{$\underline{4.1 \text { Data }}$}

Our empirical approach requires household survey data containing three types of information: (1) enrollment in the SR, (2) components of the SISBEN index (enabling us to simulate SR eligibility), and (3) potential behavioral responses and outcomes of interest (both welfare-improving and distortionary). There are two candidate Colombian household surveys that meet these criteria: the Encuestas de Calidad de Vida (ECV) and the Demographic and Health Surveys (DHS). The ECVs are nationally-representative household surveys designed to measure socio-economic well-being and “quality of life,” broadly defined. The DHS data reports detailed fertility, health, and socio-economic information for nationally-representative samples of fertile age women (defined as ages 15-49) and their households. Because the de facto implementation of the SR occurred in 1996/1997, we use the 2003 ECV and the 2005 DHS for 
our analyses. ${ }^{18}$ Table 1 shows descriptive statistics by type of behavior/outcome for the full samples as well as those with and without SR coverage.

As our empirical strategy requires, we calculate household-level SISBEN scores to simulate SR eligibility because simulated eligibility should not reflect manipulation of SISBEN scores (Camacho and Conover 2011). ${ }^{19}$ However, not all household surveys contain all necessary components of the SISBEN index. Appendix 2 provides a complete description of the SISBEN components present in each survey. ${ }^{20}$ We impute values using ordered probit models for the few variables that are missing (firm size and per-capita income in the DHS and primary roof material in both surveys).

\section{$\underline{4.2 \text { Empirical Strategy }}$}

Instrumenting for Enrollment with Simulated Eligibility

In principle, the SISBEN index’s SR eligibility threshold can be used to study behavioral responses associated with SR enrollment. This discontinuity induces an abrupt shift in eligibility (and enrollment) along otherwise smooth distributions of household characteristics; coincident shifts in behaviors and outcomes can reasonably be linked to the program. However, adverse or propitious selection into eligibility - or manipulation according to unobserved household characteristics, as discussed in Section 2.5 - is likely to bias the estimates of interest (McCrary 2008).

To circumvent this difficulty, we employ an instrumental variables strategy closely resembling one proposed by Hahn, Todd, and Van der Klaauw (2001). Conceptually, we seek to

\footnotetext{
${ }^{18}$ There was also a Colombian DHS survey conducted in 2000, but it is much smaller and contains few outcome variables of interest. We do not use the 1997 wave of the ECV because SR enrollment was still very low in that year.

${ }^{19}$ Official SISBEN scores are also not available in the datasets that we use.

${ }^{20}$ In theory, SISBEN scores should be calculated at the family (or "nucleus") level. However, we treat entire households as families given reports that SISBEN enumerators adopted this definition in practice due to difficulties in conforming to the technical definition.
} 
reconstruct 'true' SISBEN scores when both official SISBEN scores and observed SR enrollment reflect manipulation. To do so, we calculate SISBEN scores for each household in the ECV and DHS data and then use calculated scores to instrument for SR enrollment (for prominent examples of simulated instruments, see Currie and Gruber (1996a and 1996b), and Cutler and Gruber (1996), and Hoxby (2001)). ${ }^{21}$

Using urban households with simulated SISBEN scores near the urban eligibility threshold (we do not use rural households because of sufficiently inconsistent application of the rural scale $)^{22}$, we could in principle begin by estimating the following first-stage equation for individuals $i$ in household $h$ :

$$
\text { enroll }_{i h}=\alpha+\gamma \text { below }_{h}+\beta \text { SISBEN }_{h}+\Sigma_{k} \delta_{k} \text { estrato }_{h k}+\varepsilon_{i h},
$$

where enroll is an indicator for whether or not individual $i$ is enrolled in the SR, below is an indicator for simulated SISBEN score lying below the eligibility threshold, SISBEN is simulated SISBEN score, and estrato is a dummy variable for an estrato category (a neighborhood-level measure of socio-economic status used to establish electricity prices paid by local households). Using Two-Stage Least Squares (2SLS), we could then estimate the following second-stage equation:

$$
\text { outcome }_{i h}=\varphi+\lambda \text { enroll }_{i h}+\theta \operatorname{SISBEN}_{h}+\Sigma_{k} \pi_{k} \text { estrato }_{h k}+\xi_{i h},
$$

instrumeting for enroll with below. The relationship between behavioral outcomes of interest (outcome) and SR enrollment would then be captured by estimates of the parameter $\lambda$.

\footnotetext{
${ }^{21}$ We emphasize "old" SISBEN scores - those calculated using the official scale in effect between the beginning of the SR and 2003. Enrollees eligible only under the old scale were not disenrolled with the introduction of the "new scale," and the old (but not the new) eligibility discontinuity is evident in the 2005 DHS.

${ }^{22}$ The combination of smaller sample size and inconsistent application of the scale in rural areas means that our first-stage relationships are considerably weaker than in urban areas. In the DHS, the first-stage F-statistics are about 9 for the sample of children $(\mathrm{N}=574)$ and about 3 for the sample of mothers $(\mathrm{N}=302)$. In the $\mathrm{ECV}$, the firststage F-statistics are about 18, but the size of the rural sample is roughly one quarter of the urban one (1318 vs. 4129).
} 


\section{Estimating County-Specific Eligibility Thresholds}

As described in Section 2.5, financial shortfalls led many Colombian counties to use SR eligibility thresholds at SISBEN scores below the official national threshold. We therefore use county-specific eligibility thresholds. In addition to improving the strength of our first stage, this approach offers another key benefit: because some local governments use the official national threshold for other public benefits, changes in outcomes observed at county-specific SR thresholds will not reflect behavioral responses to other public programs. (Section 5.1 shows that participation in other public programs is not discontinuous at county-specific thresholds.)

Exact county-specific eligibility thresholds are unknown, so we estimate them following Chay, McEwan, and Urquiola (2005). Specifically, using our full samples, we establish countyspecific breaks in SR eligibility at the SISBEN score that maximize the goodness-of-fit of a model of SR enrollment as a function of a dichotomous indicator for whether or not a household's score falls below the threshold. ${ }^{23}$ This approach establishes thresholds that maximize the percentage of individuals correctly classified as eligible in each county. Threshold means in the ECV and DHS are 45.03 and 45.83, respectively, and their interquantile ranges are 4.96 and 3.89. Intuitively, estimated thresholds are positively correlated with current county income (the sum of taxes, transfers from the state, and non-tax income) and negatively correlated with the share of households having unmet basic needs. ${ }^{24}$

\footnotetext{
${ }^{23}$ There are 84 counties in the ECV and 220 counties in the DHS. We exclude individuals from a few counties using two criteria related to having very few observations in some counties. One is having the first percentile in the SISBEN score distribution lie above the national threshold or the $99^{\text {th }}$ percentile score lie below the national threshold. The other is having an estimated threshold with those below it having relatively lower SR enrollment rates than those above it. The total number of observations excluded for these reasons is minor (3.8\% of the sample in the ECV data and $5.2 \%$ of the sample in the DHS data). Estimated thresholds are constrained to be lower than 49. ${ }^{24}$ To assess this, we ran an OLS regression of county-specific eligibility thresholds on current county income and the share of households in the county having unmet basic needs (a composite indicator that collapses across household population density, water source, toilet availability at home, education of household head, ratio of employed household members to all household members, and children's school attendance rate). Using the ECV sample, the estimate for current county income is 0.0091 with a standard error of 0.004 ; in the DHS, the estimate is
} 
We then use county-specific thresholds to re-code the variable below for each individual $i$ in households $h$ and Colombian counties $c$ and estimate the following first stage equation:

$$
\text { enroll }_{i h c}=\alpha+\gamma \text { below }_{h c}+\beta S I S B E N_{h}+\varphi S I S B E N \_d i f f f_{h c}+\Sigma_{k} \delta_{k} \text { estrato }_{h k}+\mu_{c}+\varepsilon_{i h c},
$$

where below is now an indicator for whether or not individual i's simulated SISBEN score falls below the eligibility threshold in the individual's county $c$, SISBEN_diff is the difference between an individual's simulated SISBEN score and the estimated eligibility threshold in the individual's county (i.e., relative SISBEN score), $\mu_{c}$ represents county fixed effects (allowing us to focus on within-county variation in simulated eligibility across county-specific thresholds), and all other variables are defined as in equation (1). To adhere transparently to the identifying assumption that individuals with simulated SISBEN scores very near the threshold are comparable with the exception of their eligibility, we conservatively focus on individuals whose calculated scores lie within two index points of the county-specific cutoff (our main estimates persist across various bandwidths, as shown in Section 5.6). ${ }^{25}$

Figures 1A and 1B use ECV and DHS data to show SR enrollment and "uninsurance” by simulated SISBEN score relative to county-specific eligibility thresholds. Each county’s threshold is normalized to zero, and the figure then shows means and 95\% confidence intervals for each SISBEN index integer relative to the threshold as well as non-parametric kernel density plots on either side. The figure illustrates large discrete increases in the probability of enrollment and concomitant decreases in the probability of uninsurance at the threshold ranging between 25 to 30 percentage points. Figures 2A and 2B show the enrollment and "uninsurance" separately

0.0043 with a standard error of 0.002 . For the share of households with unmet basic needs, the estimates are -0.0456 and -0.0444 with standard errors of 0.024 and 0.015 , respectively.

${ }^{25}$ Because eligibility thresholds vary by county, our approach essentially averages across sample respondents with different absolute SISBEN scores. To investigate how our estimates vary with absolute SISBEN score, we also estimate variants of equation (4) below with interactions between SR enrollment and absolute SISBEN score (instrumenting for this term with interactions between an indicator for falling below county-specific thresholds and absolute SISBEN score) and find insignificant estimates for this interaction term (see Section 5.7). 
by regions of Colombia as well. It is worth noting than SR enrollment falls short of $100 \%$ at low (calculated) SISBEN scores. This may not only be due to mistargeting, but also to our use of household survey data (rather than official data) to construct SISBEN scores

Using our re-coded variable below to instrument for enroll, we then estimate the following equation by 2SLS:

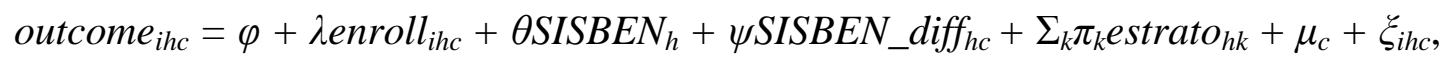

where the estimate of interest is the estimate of $\lambda .{ }^{26}$ Section 5.6 shows that our results are robust across bandwidths to including higher-order relative SISBEN score polynomials, using interactions between relative SISBEN scores and simulated eligibility, and excluding county fixed effects. We also estimate $\lambda$ using local linear regression without any covariates other than relative SISBEN score. ${ }^{27}$

\section{Limitations of the Empirical Strategy}

Although our approach addresses key irregularities in SR implementation, it also has shortcomings. First, because the ECV and DHS household survey data that we use to calculate SISBEN scores was collected after official SISBEN classification, our calculations presumably include measurement error (even absent manipulation of official SISBEN status). Second, our estimates of county-specific eligibility thresholds presumably do not match those used in practice exactly, introducing additional noise into the relationship between our measure of simulated eligibility and actual enrollment. Third, manipulation of official SISBEN scores further weakens the strength of the first stage relationship. Fourth, our sample sizes are relatively small in the neighborhood of the eligibility thresholds. Overall, these limitations clearly compromise the

\footnotetext{
${ }^{26}$ We estimate equations (3) and (4) using linear models; marginal probabilities computed using bivariate probit models yield similar results to the 2SLS estimates for dichotomous outcomes examined throughout the paper. We calculate our standard errors clustered by county.

${ }^{27}$ For comparison, we also estimate equation (4) by OLS and show the results at the bottom of our tables.
} 
power of our estimates (few are significant at significance thresholds below $\alpha=0.10$ ) and suggest that our results should also be interpreted as lower bounds.

\section{Results}

This section presents empirical evidence on a variety of important behavioral responses to the SR. We begin by demonstrating that both background characteristics not influenced by the program and participation in other social programs using SISBEN are balanced across estimated SR eligibility thresholds. We then investigate the effectiveness of health insurance in protecting households against financial risk (and possibly changing the optimal composition of household spending and assets). Next, we study changes in the use of traditionally under-utilized preventive services in light of the SR's emphasis on allocative efficiency. In doing so, we also examine changes in health outcomes that are sensitive to the use of important preventive services. We then analyze how SR enrollment is related to changes in the use of curative medicine. To investigate possible behavioral distortions, we also test for reductions in private health investments (ex ante moral hazard) and insurance 'crowd-out' associated with SR enrollment. Finally, we assess the robustness of our estimates through a variety of additional parametric and non-parametric specifications. ${ }^{28}$

\section{$\underline{5.1 \text { Balance across Discontinuous Eligibility Thresholds }}$}

Our empirical approach assumes that no individual or household characteristics - other than SR enrollment - that could influence the outcomes of interest vary discontinuously across our estimated eligibility thresholds. To test this assumption, Table 2 shows results obtained by

\footnotetext{
${ }^{28}$ As expected, power is lower in all analyses if we use the uniform national threshold rather than estimated countyspecific ones. In contrast to the F statistics shown in our main tables, using the uniform national threshold yields first stage F statics of 4.7 in the ECV and 18 in the DHS. Even so, many of our key results on health care use and health outcomes are nonetheless present when we use the uniform national threshold.
} 
estimating equations (3) and (4) for individual attributes that could not reasonably change in response to SR enrollment (such as age or educational attainment among adults). Consistent with our assumption, the estimates are not generally distinguishable from zero. (Examining the distribution of simulated SISBEN scores across eligibility discontinuities, Appendix 3 shows evidence in support of this assumption as well.)

We then consider whether or not our estimates from equation (4) could be attributed to participation in other public programs that also use the SISBEN index. Before investigating this possibility directly, we first note that it is unlikely because these programs use the uniform national eligibility threshold, while we estimate and utilize de facto county-specific thresholds for the SR - many of which fall below the uniform national threshold. To confirm this, we reestimate equations (3) and (4) using a dichotomous indicator for participation in these other programs - including job training, home mortgage subsidies, education vouchers, Hogares Comunitarios (a large child care program), and services provided by the Instituto Colombiano de Bienestar Familiar (the largest social welfare agency in Colombia) - as the dependent variable in equation (4). ${ }^{29}$ Table 2 presents these results, suggesting that participation in other programs is also balanced across county-specific SR eligibility thresholds.

\subsection{Financial Risk Protection and Portfolio Choice}

Although a key innovation of the SR is its emphasis on allocative efficiency, a central objective of any health insurance program is to provide protection against financial risk. We therefore begin by examining the relationship between SR enrollment and both level and

\footnotetext{
${ }^{29}$ The program Empleo en Acción (a workfare program active in 2003 but abolished in 2004) is the only public program of which we are aware that used the uniform national SISBEN eligibility threshold for which the 2003 ECV does not contain data. Participation in the program was low (only $7.4 \%$ of those in SISBEN strata 1 or 2 ) and provided no benefits directly related to health (it paid $60 \%$ of the minimum wage to individuals who worked on official program projects an average of at least 30 hours per week for 2.4 months) (IFS-SEI-Econometria 2005). We do not have information about participation in Familias en Acción, a Colombian conditional cash transfer program, but the eligibility threshold for this program (36) is considerably lower, falling more than two standard deviations below the mean of our estimated SR thresholds.
} 
variability of out-of-pocket medical spending. To construct our variability measure, we first calculate mean individual spending separately among those enrolled and those not enrolled in the SR. For each individual, we then measure the difference between each individual's spending and the mean among those with the same enrollment status, constructing our variability measure as the absolute value of this difference. We analyze outpatient and inpatient out-of-pocket spending (within the past twelve months) separately and emphasize the latter because of idiosyncrasies in how outpatient spending is reported. ${ }^{30}$

We first graphically examine shifts in the distribution of medical spending associated with simulated eligibility for the SR. Figure 3 shows cumulative density functions for inpatient medical spending in the preceding year separately for those falling above and below countyspecific thresholds (using our sample of those within two index points of the cutoff). ${ }^{31}$ Both distributions are heavily right-skewed, but mass in the distribution for those who are eligible (those below the threshold) falls to the left of the distribution for those who are ineligible. No clearly comparable pattern is present for outpatient medical spending (Figure 4). Overall, these figures suggest that SR eligibility is associated with reductions in right-tail inpatient medical spending - a pattern consistent with risk protection. ${ }^{32}$

The first four columns of Panel A in Table 3 then present econometric results obtained by estimating equations (3) and (4) for medical spending by type. The first row presents IV

\footnotetext{
${ }^{30}$ The ECV 2003 question about outpatient spending in the preceding 30 days excludes outpatient costs associated with illness ultimately leading to hospitalization; the inpatient expenditure question asks about all inpatient spending in the past 12 months.

${ }^{31}$ These graphs do not correspond exactly to our formal RD estimates for several reasons. One is that they only include observations with positive expenditures and hence do not capture differential selection into any spending between those above vs. below the eligibility threshold. Another is that using our bandwidth of two sample, they depict mean differences between those above vs. below the eligibility threshold (rather than differences between the two groups as one converges to the threshold from above vs. below). Conducting a Kolmogorov-Smirnov test for equality of distributions, we are unable to reject the null hypothesis of equality, presumably because of these limitations and small sample sizes when conditioning on any spending. They are nonetheless suggestive.

${ }^{32}$ These figures may understate the magnitude of risk protection under the SR for two reasons: (1) some people may not receive medical care at all, but nonetheless incur non-medical financial expenses due to poor health, and (2) the figures show densities by eligibility rather than enrollment status (because enrollment is endogenous).
} 
estimates for SR enrollment, and the second row reports intent-to-treat (ITT) estimates for simulated SR eligibility (estimates for a dummy variable coding whether or not an individual falls below the eligibility threshold obtained by OLS regressions of outcomes on this dummy and the other covariates in equation 4). The first column suggests that SR enrollment lowers mean inpatient spending by about 60,000 pesos $(\alpha=0.10)$, around a $30 \%$ reduction among those using any inpatient services. Perhaps more importantly for assessing protection against financial risk, the third column shows that SR enrollment is associated with reductions in the variability of inpatient medical spending ( $\alpha=0.05){ }^{33}$ There is no statistically significant association for outpatient care. Appendix 4 Figure 1 graphically shows all outcomes examined in Panel A across county-specific eligibility thresholds (essentially, graphical versions of our intent-to-treat analyses).

Overall, the results shown in Table 3 Panel A suggest that SR enrollment is associated with meaningful risk protection benefits. By reducing household exposure to financial risk, SR enrollment could also produce meaningful changes in the composition of household assets, human capital investments, and household consumption (i.e., portfolio choice effects). Specifically, it may increase investments not previously undertaken because of costly informal risk-management activities (such as precautionary saving). Panel B of Table 3 presents estimates for durable goods not used to construct the SISBEN index (car and radio ownership) as well as household education and consumption expenditures. In general, it implies that SR enrollment is not associated with discernible portfolio choice effects (perhaps because the SR falls short of providing full insurance).

\footnotetext{
${ }^{33}$ Although this result is unsurprising given that Colombia's reform caps the amount that SR enrollees are required to pay out-of-pocket, it cannot be taken for granted in a developing country context. For example, Wagstaff and Lindelow (2008) find that health insurance in China increases financial risk due to a combination of poor regulation and asymmetric information.
} 


\subsection{Preventive Service Use and Health Status}

As described earlier, a key innovation of the SR is its focus on improving allocative efficiency in medical care. In particular, increasing the use of highly beneficial preventive services - many of which produce large positive externalities - is likely to improve welfare. These externalities are due both to reduced rates of infectious disease transmission and to reduced curative care costs borne by others through risk pools.

The first two columns of Table 4 report estimates for different types of preventive care use obtained from equations (3) and (4) (Appendix 4 Figure 2 shows graphical versions of the intent-to-treat analyses). In general, they suggest substantial increases in the use of preventive health care services. ${ }^{34}$ Specifically, SR enrollment is associated with a 29 percentage point increase in the probability of a preventive physician visit in the past year (a 75\% increase; $\alpha=0.01$ ). Importantly, the SR is also associated with 1.50 more growth-monitoring and well-care visits in the past year, a 50\% increase relative to uninsured children $(\alpha=0.05)$. These well-care visits are a principal way of addressing important childhood health problems (parents receive nutritional advice, iron supplements, and de-worming medications, for example - which are important for strengthening children's immune systems and making them less susceptible to major childhood illnesses such as severe diarrhea and acute respiratory infections/pneumonia). ${ }^{35}$

We then investigate whether or not health status has improved under the SR - in particular, dimensions of health that are sensitive to the use of preventive care. Although our preventive physician visit variable is not service-specific, our measure of childhood growth and development checks should correspond directly with infectious disease prevalence. Columns

\footnotetext{
${ }^{34}$ This increase in preventive care use dominates any ex ante moral hazard (which would reduce prevention although Section 5.5 suggests no evidence of ex ante moral hazard).

${ }^{35}$ See Fogel (1994), Santos et al. (2001), Alderman (2007), Currie et al. (2008), Galasso and Umapathi (2009), and Linnemayr and Alderman (2011) on the relationship between preventive care and child health.
} 
three through six of Table 4 show estimates for child health outcomes linked to preventive care use. SR enrollment is associated with 1.4 fewer child days absent from usual activities due to illness in the past month $(\alpha=0.05)$. Enrollment is also associated with an 18 percentage point reduction in the self-reported incidence of cough, fever, or diarrhea among children in the preceding two weeks (but it is not statistically significant at conventional levels). Appendix 4 Figure 2 shows graphical versions of the intent-to-treat analyses for these health outcomes as well. ${ }^{36}$ Because these health gains can be linked to increases in preventive service use, they are also likely to improve welfare.

\subsection{Use of Curative Medical Care}

As Section 3 discusses, there are a variety of competing incentives and other forces influencing curative medical care under the SR. These include reductions in out-of-pocket prices, increases in the use of preventive services, and supply-side incentives for limiting total medical spending. Predictions about changes in curative service use under the SR - and their welfare implications - are therefore ambiguous, but they remain a central interest of policymakers and are important for assessing the costs of Colombia's innovative health insurance reform.

Table 5 reports estimates for various categories of curative care obtained from equations (3) and (4) (Appendix 4 Figure 3 shows graphical versions of the intent-to-treat analyses). We find that SR enrollment is associated with a 13 percentage point increase in reported physician visits because of health problems within the past 30 days $(\alpha=0.05)$. There is no change in use of curative care among children, which may be due to improvements in child health associated with

\footnotetext{
${ }^{36}$ Interestingly, for some of the more statistically pronounced results (such as physician visits for preventive care and children's healthy days lost due to illness), the graphical pattern of results shown in Figure 2 Appendix 4 closely resemble the graphical pattern enrollment in the SR shown in Figure 1: a more or less flat relationship to the left of the threshold, and a monotonic relationship to the right of the threshold. Although suggestive, these shape similarities must still be interpreted cautiously.
} 
SR enrollment (as Table 4 shows). Finally, there is no meaningful relationship at conventional significance levels between participation in the SR and hospitalizations.

\section{$\underline{5.5 \text { Ex Ante Moral Hazard and Insurance Crowd-Out }}$}

Protection from financial risk associated with unexpected illness weakens private incentives for costly health protection (ex ante moral hazard) (Pauly 1968). Because we find evidence of greater risk protection, we investigate how protective private health behaviors not directly linked to medical care change with SR enrollment. ${ }^{37}$ As Table 6 and Appendix 4 Figure 4 show, however, we find no meaningful change in breastfeeding or maternal investments in fetal health (alcohol, drug, or tobacco use during pregnancy; or prenatal dietary supplementation with iron, calcium, or folic acid), suggesting little ex ante moral hazard associated with SR enrollment. ${ }^{38}$

Manipulation of official SISBEN scores suggests that Colombians perceive benefits of SR enrollment, so we also investigate the possibility that SR enrollment displaces other forms of explicit health insurance. ${ }^{39}$ Table 6 also presents intent-to-treat (ITT) estimates obtained by estimating equation (3) with dichotomous indicators for Regimen Contributivo enrollment, other forms of health insurance (those for the military, police officers, and certain industrial groups like oil industry workers, for example), and "uninsurance" as dependent variables. The Regimen Contributivo estimates are generally small (-0.02 in the ECV and -0.05 in the DHS) and the latter is statistically significant $(\alpha=0.05)$, suggesting that some modest crowding-out of formal insurance may have occurred.

\footnotetext{
${ }^{37}$ More generally, private health behaviors and public health services could theoretically be either complements or substitutes for publicly provided health services. While reductions in the price of medical care may raise the return to private health investments given competing risks, cheaper health services could also instead 'crowd-out' costly private health behaviors (Dow, Holmes, Philipson, and Sala-i-Martin 1999, Murphy and Topel 2003).

${ }^{38}$ We cannot rule-out the possibility that social desirability bias in reporting might attenuate a true effect.

${ }^{39}$ Formal sector employees are mandated to enroll in an employment-based health insurance system called Regimen Contributivo. This mandate holds even for individuals with SISBEN scores falling below the SISBEN eligibility threshold for the SR.
} 


\subsection{Robustness}

To investigate the robustness of our results, we estimate a variety of alternative parametric and non-parametric specifications based on our main estimating equations. First, we re-estimate equations (3) and (4) using SISBEN score bandwidths ranging between two and four. Second, at each bandwidth we estimate specifications that include higher order polynomials of relative SISBEN scores (including squared, cubic, and fourth power terms) as well as models that include interactions between relative SISBEN scores and simulated eligibility (although allowing SISBEN gradients to vary on either side of the eligibility threshold should matter little given our narrow bandwidth). Third, we re-estimate specifications that do not include county fixed effects (at each bandwidth), allowing us also to make cross-county comparisons among individuals with identical simulated SISBEN scores but that fall on opposite sides of countyspecific eligibility thresholds. Finally, we also estimate models using non-parametric local linear regression. ${ }^{40}$ As Tables 1-4 of Appendix 5 show that our results are generally robust (with some variation in precision) across these alternative bandwidths and specifications.

\section{$\underline{5.7 \text { Heterogeneity and External Validity }}$}

While RD estimates can have good internal validity, their external validity is often limited because they typically utilize a sample only in the neighborhood of the discontinuity (Imbens and Lemieux 2008, Lee and Lemieux 2010). However, because SR eligibility thresholds vary by county, our empirical strategy allows us to investigate the external validity of our estimates by extending equation (4) to include interactions between absolute SISBEN score and SR

\footnotetext{
${ }^{40}$ Specifically, we use local linear regression functions with triangle kernels to estimate conditional means of outcome variables (conditioning on SISBEN_diff) on either side of the eligibility threshold, and we repeat this estimation process for enrollment in the SR. We then construct Wald statistics using differences in the estimated conditional means of the outcome variable on either side of the threshold as numerators and the difference in the conditional mean of SR enrollment on either side of the threshold as the denominator. We estimate our standard errors using 250 bootstrap replications. Details of the implementation can be found in Nichols (2007).
} 
enrollment. ${ }^{41}$ This allows us to test for heterogeneity by SISBEN score, a summary measure of socio-economic status. As Appendix 6 Tables 1-4 show, we find little evidence of heterogeneous effects, suggesting that our estimates are not sensitive to local variation in SISBEN scores and may therefore apply to a broader range of the Colombian population. ${ }^{42}$ We note, however, that the interaction terms' standard errors are large, so our power to detect heterogeneity is limited.

\section{Conclusion}

This paper studies the role of Colombia's Régimen Subsidiado in protecting the poor against financial risk, influencing their use of health services, and ultimately affecting their health status. Unusual among middle- and low-income countries at the time of its introduction, the SR is a publicly-financed health insurance program with features of managed care emphasizing allocative efficiency that are traditionally only found in wealthy countries. We find evidence that the SR provides some protection against financial risk and is associated with greater use of preventive services having positive externalities - as well as with measurable health gains among children.

Pinpointing the mechanisms through which complex insurance programs such as SR work is an important topic of future research. In our case, because preventive services are generally free regardless of insurance status, one plausible interpretation of the increase in prevention that we observe links them to the SR's high-powered supply-side incentives (if

\footnotetext{
${ }^{41}$ Specifically, we estimate: outcome $e_{i h c}=\varphi+\lambda$ enroll $_{i h c}+\theta S I S B E N_{h}+\delta\left(\right.$ enroll $\left._{i h c} \times S I S B E N_{h}\right)+\psi S I S B E N \_d i f f$ hc + $\Sigma_{k} \pi_{k}$ estrato $_{h k}+\mu_{c}+\xi_{\text {ihc }}$, using below hc $_{\text {ch }}$ and (below $w_{\mathrm{hc}} \times$ SISBEN $_{h}$ ) as instruments. All variables are defined as in equations (3) and (4).

${ }^{42}$ The fifth row of Appendix 6 Tables 1-4 shows implied effects of Subsidized Regime enrollment evaluated at the average SISBEN score (45) and their accompanying p-values. The magnitude and significance of these effect sizes generally match the estimates in Tables 3-6.
} 
providers with capitated contracts believe that prevention is cost-saving). Another potentially important channel is patient substitution from public to private sector providers contracting with insurance plans under the SR (if private providers were more likely to supply preventive care). Although we suspect that these two mechanisms may be most salient, we cannot rule out others (individual feeling more comfortable going to the doctor when insured, the provision of insurance making the universal entitlement to preventive care more salient, etc.).

We conclude by emphasizing that the welfare-improving potential of SR has yet to be fully realized. For example, a variety of political concessions followed the creation of the SR including exemptions from the end of government subsidies as well as requirements that insurers contract with public facilities for a minimum share of the services that they finance. These concessions presumably limit the ability of health plans to contract with medical care providers in ways that best encourage higher quality and lower cost services. 


\section{References}

Abel-Smith, Brian. 1992. "Health Insurance in Developing Counties: Lessons from Experience.” Health Policy and Planning 7(3): 215-226.

Alderman, Harold. 2007. "Improving Nutrition Through Community Growth Promotion: Longitudinal Study of the Nutrition and Early Child Development Program in Uganda." World Development 35 (8) (August): 1376-1389.

Anderson, Michael, Carlos Dobkin, and Tal Gross. 2012. "The Effect of Health Insurance Coverage on the Use of Medical Services.” American Economic Journal: Economic Policy 4(1): 1-27.

Arrow, Kenneth. 1963. "Uncertainty and the Welfare Economics of Medical Care." The American Economic Review 53: 941-973.

BDO International and Corporación Centro Regional de Población (CCRP). 2000. Evaluation of SISBEN: Efficiency, Institutional Efficacy of the Identification, Classification and Beneficiary Selection Processes. Bogotá: Ministry of Health.

Bhushan, I., E. Bloom, D. Clingingsmith, R. Hong, E. King, M. Kremer, B. Loevinsohn, and B. Schwartz. 2006. "Contracting for Health: Evidence from Cambodia." Unpublished Manuscript. Harvard University.

Black, Robert E., Saul S. Morris, and Jennifer Bryce. 2003. "Where and Why are 10 Million Children Dying Every Year?” The Lancet 361: 2226-2234.

Camacho, Adriana and Emily Conover. 2008. "Effects of Subsidized Health Insurance on Newborn Health in a Developing Country." Centro de Estudios sobre Desarrollo Económico (CEDE) Working Paper 14, Universidad de Los Andes.

------. 2011. “Manipulation of Social Program Eligibility.” American Economic Journal: Economic Policy 3 (2): 41-65.

Card, David, Carlos Dobkin, and Nicole Maestas. 2008. "The Impact of Nearly Universal Coverage on Health Care: Evidence from Medicare.” American Economic Review 98(5): 2242-2258

------. 2009. “Does Medicare Save Lives?” Quarterly Journal of Economics 124(2): 597-636.

CENDEX. 2008. Resultados de la Encuesta Nacional de Salud 2007. Power point presentation available online at: http://www.cendex.org.co.

Chandra, Amitabh, Jonathan Gruber, and Robin McKnight. 2010a. "Patient Cost-Sharing in Low Income Populations.” American Economic Review Papers and Proceedings 100(2): 303-308.

------. 2010b. "Patient Cost-Sharing and Hospitalization Offsets in the Elderly." American Economic Review 100(1): 193-213.

Chaudhury, Nazmul and Jeffrey Hammer. 2004. "Ghost Doctors: Absenteeism in Rural Bangladeshi Health Facilities.” World Bank Economic Review 18(3): 423-441.

Chay, Kenneth Y., Patrick J. McEwan, and Miguel Urquiola. 2005. “The Central Role of Noise in Evaluating Interventions that Use Test Scores to Rank Schools." American Economic Review 95(4): 1237-1258. 
Cohen, Joshua T., Peter J. Neumann, and Milton C. Weinstein. 2008. "Does Preventive Care Save Money? Health Economics and the Presidential Candidates.” New England Journal of Medicine 358 (7): 661-663.

Currie, Janet and Jonathan Gruber. 1996a. "Health Insurance Eligibility, Utilization of Medical Care, and Child Health.” Quarterly Journal of Economics 111(2): 431-466.

------. 1996b. "Saving Babies: The Efficacy and Cost of Recent Changes in the Medicaid Eligibility of Pregnant Women.” Journal of Political Economy 104(6): 1263-96.

Currie, Janet, Sandra Decker, and Wanchuan Lin. 2008. "Has Public Health Insurance for Older Children Reduced Disparities in Access to Care and Health Outcomes?” Journal of Health Economics, 27 (6): 1407-1652.

Cutler, David M. 2002. "Health Care and the Public Sector.” In Handbook of Public Economics 4, ed. A. Auerbach and M. Feldstein. Amsterdam: Elsevier.

Cutler, David and Jonathan Gruber. 1996. "Does Public Insurance Crowd Out Private Insurance?” Quarterly Journal of Economics 111(2): 391-430.

Cutler, David and Richard Zeckhauser. 2000. “The Anatomy of Health Insurance.” In Handbook of Health Economics 1, ed. A. J. Culyer \& J. P. Newhouse. Chapter 11. Amsterdam: Elsevier.

Dafny, Leemore and Jonathan Gruber. 2005. "Public Insurance and Child Hospitalizations: Access and Efficiency Effects.” Journal of Public Economics 89(1): 109-129.

Das, Jishnu and Jeffrey Hammer. 2007. "Money for Nothing: The Dire Straits of Medical Practice in Delhi, India.” Journal of Development Economics 83(1): 1-36.

Dave, Dhaval and Robert Kaestner. 2006. "Health Insurance and Ex-ante Moral Hazard: Evidence from Medicare.” NBER Working Paper 12764, Cambridge, MA.

Department of National Planning (DNP). 2004. Programa Familias en Acción - Condiciones Iniciales de los Beneficiarios e Impactos Preliminares. Bogotá: Department of National Planning.

Department of National Planning (DNP) and Ministry of Social Protection. 2001. Proceedings of the National Conference on SISBEN: Integral Evaluation. Bogotá: Department of National Planning.

------. 2003a. Who Benefits from SISBEN? Integral Evaluation. Bogotá: Department of National Planning.

------. 2003b. Results of the Evaluation Survey of SISBEN at the Municipal Level. Bogotá: Department of National Planning.

Dow, William, Paul Gertler, Robert Schoeni, John Strauss, and Duncan Thomas. 1997. "Health Care Prices, Health, and Labor Outcomes: Experimental Evidence.” Labor and Population Working Paper 97-01, RAND.

Dow, William, Tomas Philipson, and Xavier Sala-i-Martin. 1999. "Longevity Complementarities under Competing Risks.” American Economic Review 89(5): 1358-1371.

Dow, William, Gonzalez, Kristine and Luis Rosero-Bixby. 2003. “Aggregation and InsuranceMortality Estimation.” NBER Working Paper 9827, Cambridge, MA. 
Dow, William and Kammi K. Schmeer. 2003. "Health Insurance and Child Mortality in Costa Rica.” Social Science and Medicine 57(6): 975-986.

Doyle, Joseph. 2005. "Health Insurance, Treatment and Outcomes: Using Auto Accidents as Health Shocks.” Review of Economics and Statistics 87(2): 256-270.

Duflo, Esther, Abhijit Banerjee, and Angus Deaton. 2004. "Wealth, Health, and Health Services in Rural Rajasthan.” American Economic Review Papers and Proceedings 94(2): 326-330.

Ellis, Randall and Thomas McGuire. 1990. "Optimal Payment Systems for Health Services.” Journal of Health Economics 9: 375-396.

-----. 1993. “Supply-Side and Demand-Side Cost Sharing In Health Care,” Journal of Economic Perspectives 7(4): 135-151.

Enthoven, Alain. 1978. “Consumer Choice Health Plan (first of two parts). Inflation and Inequity in Health Care Today: Alternatives for Cost Control and an Analysis of Proposals for National Health Insurance.” New England Journal of Medicine 298: 650-658.

------. 1978. "Consumer Choice Health Plan (second of two parts). A National Health Insurance Proposal Based on Regulated Competition in the Private Sector.” New England Journal of Medicine 298: 709-720.

Escobar, Maria Luisa. 2005. "Health sector reform in Colombia.” in Development Outreach Magazine. World Bank Institute, Washington, D.C.

Filmer, Deon, Jeffrey Hammer, and Lant H. Pritchett. 2000. "Weak Links in the Chain: A Diagnosis of Health Policy in Poor Countries.” World Bank Research Observer 15(2): 199224.

Finkelstein, Amy 2007. "The Aggregate Effects of Health Insurance: Evidence from the Introduction of Medicare,” Quarterly Journal of Economics 122(3): 1-37.

Finkelstein, Amy and Robin McKnight. 2008. "What Did Medicare Do? The Initial Impact of Medicare on Mortality and Out of Pocket Medical Spending.” Journal of Public Economics 92(7): 1644-1669.

Fiszbein, Ariel and Norbert Schady. 2009. Conditional Cash Transfers - Reducing Present and Future Poverty. The World Bank, Washington D.C.

Fogel, Robert. 1994. "Economic Growth, Population Theory, and Physiology: The Bearing of Long-term Processes on the Making of Economic Policy," American Economic Review 84(3): 369-395.

Fresneda, Bautista. 2003. "Focusing on the subsidized health regime in Colombia," Revista Salud Pública 5(3): 209-245.

Fuchs, Victor. 1974. Who Shall Live? Health, Economics, and Social Choice. Singapore: World Scientific Publishing Company.

Gakidou, E., R. Lozano, E. Gonzalez-Pier, J. Abbott-Klafter, and J. Barofsky. 2006. “Assessing the Effect of the 2001-2006 Mexican Health Reform: An Interim Report Card.” The Lancet 368: 1920-1935. 
Galasso, Emanuela and Nithin Umapathi. 2009. "Improving Nutritional Status Through Behavioural Change: Lessons from Madagascar.” Journal of Development Effectiveness 1 (1): 60-85.

Gaviria, Alejandro, Carlos Medina, and Carolina Mejía. 2007. "Assessing Health Reform in Colombia: From Theory to Practice.” Economía 7(1): 29-72.

Gertler, Paul. 2004. "Do Conditional Cash Transfers Improve Child Health? Evidence from PROGRESA's Control Randomized Experiment." American Economic Review Papers and Proceedings 94(2): 336-341.

Gertler, Paul and Jonathan Gruber. 2002. "Insuring Consumption against Illness," American Economic Review 92(1): 51-70.

Gertler, Paul and Orville Solon. 2002. "Who Benefits From Social Health Insurance? Evidence from the Philippines,” Unpublished Manuscript, University of California, Berkeley and the University of the Philippines.

Gruber, Jonathan, Hendren, Nathaniel and Robert Townsend. 2012 "Demand and Reimbursement Effects of Healthcare Reform: Health Care Utilization and Infant Mortality in Thailand,” NBER Working Paper 17739, Cambridge, MA.

Giedion, Ursula and Manuela Uribe. 2009. “Colombia’s Universal Health Insurance System.” Health Affairs 28(3): 853-863.

Giedion, Uusula, Beatrice Díaz, Educardo Alfonso, and William Savedoff. 2009. "The Impact of Subsidized Health Insurance on Health Status and on Access to and Use of Health Services.” In Glassman, A., Giuffrida, A., Escobar, M-L., and U. Giedion (eds.) From Few to Many: Ten Years of Health Insurance Expansion in Colombia. Inter-American Development Bank and The Brookings Institution, Washington, D.C.

GTZ, ILO and WHO. 2005. Recommendations for Action. The International Conference on Social Health Insurance in Developing Countries. Geneva: GTZ, ILO, and WHO.

Gwatkin, Davidson R, Adam Wagstaff, and Abdo S. Yazbeck. 2005. Reaching the Poor with Health, Nutrition and Population Services: What Works, What Doesn't, and Why. World Bank. Washington, D. C.

Hahn, Jinyong, Petra Todd, and Wilbert Van der Klaauw. 2001. "Identification and Estimation of Treatment Effects with a Regression-Discontinuity Design.” Econometrica 69(1): 201209.

Holmstrom, Bengt and Paul Milgrom. 1991. "Multitask Principal-Agent Analyses: Incentive Contracts, Asset Ownership, and Job Design.” Journal of Law, Economics and Organization 7: 24-52.

Hoxby, Caroline. 2001. “All School Finance Equalizations Are Not Created Equal.” Quarterly Journal of Economics 116(4): 1189-1231.

Hughes, David and Songkramchai Leethongdee. 2007. "Universal Coverage in the Land of Smiles: Lessons from Thailand’s 30 Baht Health Reforms.” Health Affairs 26(4): 999-1008.

IFS-SEI-Econometria. 2005. Evaluación de Impacto del Programa Empleo en Acción (Volume VI). Bogotá: National Planning Department. 
Imbens, Guido and Thomas Lemieux. 2008. "Regression Discontinuity Designs: A Guide to Practice.” Journal of Econometrics 142(2): 615-635.

Keenan, P., M. Elliott, P. Cleary, A. Zaslavsky, and M. Landon. 2009. “Quality Assessments by Sick and Healthy Beneficiaries in Traditional Medicare and Medicare Managed Care.” Medical Care 47(8): 882-888.

Kenkel, Donald. 2000. “Prevention.” In Handbook of Health Economics 1, ed. A. J. Culyer \& J. P. Newhouse. Edition 1, Chapter 31. Amsterdam: Elsevier.

Kolstad, Jonathan and Amanda Kowalski. 2010. "The Impact of Health Care Reform on Hospital and Preventive Care: Evidence from Massachusetts.” NBER Working Paper 16012, Cambridge, MA.

Kowlaski, Amanda. 2011. "Estimating the Trade-off between Risk Protection and Moral Hazard with a Nonlinear Budget Set Model of Health Insurance.” Unpublished Manuscript, Yale University.

Lagarde, Mylene, Andy Haines, and Natasha Palmer. 2007. “Conditional Cash Transfers for Improving Uptake of Health Interventions in Low- and Middle-Income Countries: A Systematic Review.” Journal of the American Medical Association 298(16): 1900-1910.

Lee, David and Thomas Lemieux. 2010. "Regression Discontinuity Designs in Economics." Journal of Economic Literature 48: 281-355.

Lennon, M. A., H. V. Worthington, P. Coventry, A. C. Mellor, and P. J. Holloway. 1990. 'The Capitation Study. 2. Does Capitation Encourage More Prevention?’ British Dental Journal 168 (5) (March 10): 213-215.

Levy, Helen and David Meltzer. 2004. "What Do We Really Know about Whether Health Insurance Affects Health?” In Health Policy and the Uninsured: Setting the Agenda, edited by C. McLaughlin. Washington, DC: Urban Institute Press.

Linnemayr, Sebastian, and Harold Alderman. 2011. “Almost Random: Evaluating a Large-scale Randomized Nutrition Program in the Presence of Crossover." Journal of Development Economics 96 (1) (September): 106-114.

Ma, Albert C. and Thomas McGuire. 1997. “Optimal Health Insurance and Provider Payment.” American Economic Review 87: 685-704.

Manning, Willard, Arleen Leibowitz, George Goldberg, Joseph Newhouse, and William Rogers. 1984. "A Controlled Trial of the Effect of a Prepaid Group Practice on Use of Services”, New England Journal of Medicine 310 (23): 1505-1510.

McGuire, Thomas. 2000. "Physician Agency.” In Handbook of Health Economics 1, ed. A. J. Culyer \& J. P. Newhouse. Edition 1, Chapter 9. Amsterdam: Elsevier.

Miller, Robert H., and Harold S. Luft. 1994. "Managed Care Plan Performance Since 1980A Literature Analysis.” Journal of the American Medical Association 271 (19) (May 18): 15121519.

Mohanan, Manoj. 2012. “Causal Effects of Health Shocks on Consumption and Debt: QuasiExperimental Evidence from Bus Accident Injuries.” The Review of Economic and Statistics. Forthcoming. 
Morduch, Jonathan. 1995. "Income Smoothing and Consumption Smoothing." Journal of Economic Perspectives 9(3): 103 - 114.

------. 1999. “The Microfinance Promise,” Journal of Economic Literature 37(4): 1569-1614.

Muralidharan, Karthik and Venkatesh Sundararaman. 2011. "Teacher Performance Pay: Experimental Evidence from India.” Journal of Political Economy 119: 39-77.

Murphy, Kevin. M., and Robert H. Topel. 2006. “The Value of Health and Longevity.” Journal of Political Economy 114: 871-904.

Newhouse, J. and the Insurance Experiment Group. 1993. Free for All? Lessons from the RAND

Health Insurance Experiment. Cambridge, MA: Harvard University Press.

Newhouse, Joseph. P. 2002. Pricing the Priceless - A Health Care Conundrum. Cambridge, MA: MIT Press.

Nichols, Austin. 2007. rd: Stata Module for Regression Discontinuity Estimation. Available online at: http://ideas.repec.org/c/boc/bocode/s456888.html.

Nordquist, Gerald and S. David Wu. 1976. "The Joint Demand for Health Insurance and Preventive Medicine.” In The Role of Health Insurance in the Health Services Sector, ed. R. Rosett. New York: National Bureau of Economic Research.

Odonnell, O. et al. 2008. “Who Pays for Health Care in Asia?” Journal of Health Economics 27: 460-475.

Panopoulus, G. and C. Vélez. 2001. "Subsidized Health Insurance, Proxy Means Testing, and the Demand for Health Care among the Poor in Colombia," in Colombia Poverty Report (Volume 2). Washington, D.C.: The World Bank.

Pauly, Mark. 1968. “The Economics of Moral Hazard,” American Economic Review 49: 531537.

Pauly, Mark, Frederic E. Blavin, and Sudha Meghan. 2008. "Is There a Market for Voluntary Health Insurance in Developing Countries?” NBER Working Paper 14095, Cambridge, MA.

Pauly, Mark, Peter Zweifel, Richard Scheffler, Alexander Preker, and Mark Bassett. 2006. "Private Health Insurance in Developing Countries." Health Affairs 25(2): 369-379.

Paxson, Christina. 1993. “Consumption and Income Seasonality in Thailand," Journal of PoliticalEconomy 101(1): 39-72.

Phelps, Charles. 1978. "Illness Prevention and Medical Insurance.” Journal of Human Resources 13: 183-207.

Pinto, Diana. 2008. "Good Practices in Expanding Health Care Coverage.” In Gottret P., Schieber, G.J., and H.R. Waters (eds), Good Practices in Health Financing Lessons from Reforms in Low and Middle-Income Countries. The International Bank for Reconstruction and Development/The World Bank. Washington DC.

Pitt, Mark and Shahidur Khandker. 1998. "The Impact of Group-Based Credit Programs on Poor Households in Bangladesh: Does the Gender of Participants Matter?” Journal of Political Economy 106(5): 958-996. 
Santos, Iná, Cesar Victora, José Martines, Helen Gonçalves, Denise Gigante, Neiva Valle, and Gretel Pelto. 2001. "Nutrition Counseling Increases Weight Gain Among Brazilian Children.” The Journal of Nutrition 131 (11) (November): 2866-2873.

Townsend, Robert. 1994. “Risk and Insurance in Village India.” Econometrica 62(3): 539-591.

Trujillo, Antonio, Jorge Portillo, and John Vernon. 2005. “The Impact of Subsidized Health Insurance for the Poor: Evaluating the Colombian Experience Using Propensity Score Matching.” International Journal of Health Care Finance and Economics 5(3): 211-239.

Wagstaff, Adam. 2007. "Health Insurance for the Poor: Initial Impacts of Vietnam's Health Care Fund for the Poor.” Policy Research Paper Series Working Paper 4134, The World Bank.

Wagstaff, Adam and Shengchao Yu. 2007. "Do Health Sector Reforms Have Their Intended Impacts? The World Bank's Health VIII Project in Gansu Province, China,” Journal of Health Economics 26: 505-535.

WHO Commission on Macroeconomics and Health. 2001. Macroeconomics and Health: Investing in Health for Economic Development. Geneva, Switzerland: World Health Organization.

WHO. 2010. The World Health Report: Health Systems Financing: the Path to Universal Coverage. Geneva, World Health Organization.

Xu, Ke, David Evans, Kei Kawabata, Riadh Zeramdini, Jan Klavus, and Christopher Murray. 2003. "Household Catastrophic Health Expenditure: A Multicountry Analysis." The Lancet 362(9378): 111-117.

Wagstaff, Adam and Magnus Lindelow. 2008. “Can Insurance Increase Financial Risk?” Journal of Health Economics 27 (4) (July): 990-1005.

Zeckhauser, Richard. 1970. "Medical Insurance: A Case Study of the Tradeoff between Risk Spreading and Appropriate Incentives.” Journal of Economic Theory 2(1): 10-26. 
Figure 1A: Subsidized Regime Enrollment and 'Uninsurance' across SISBEN Eligibility Thresholds
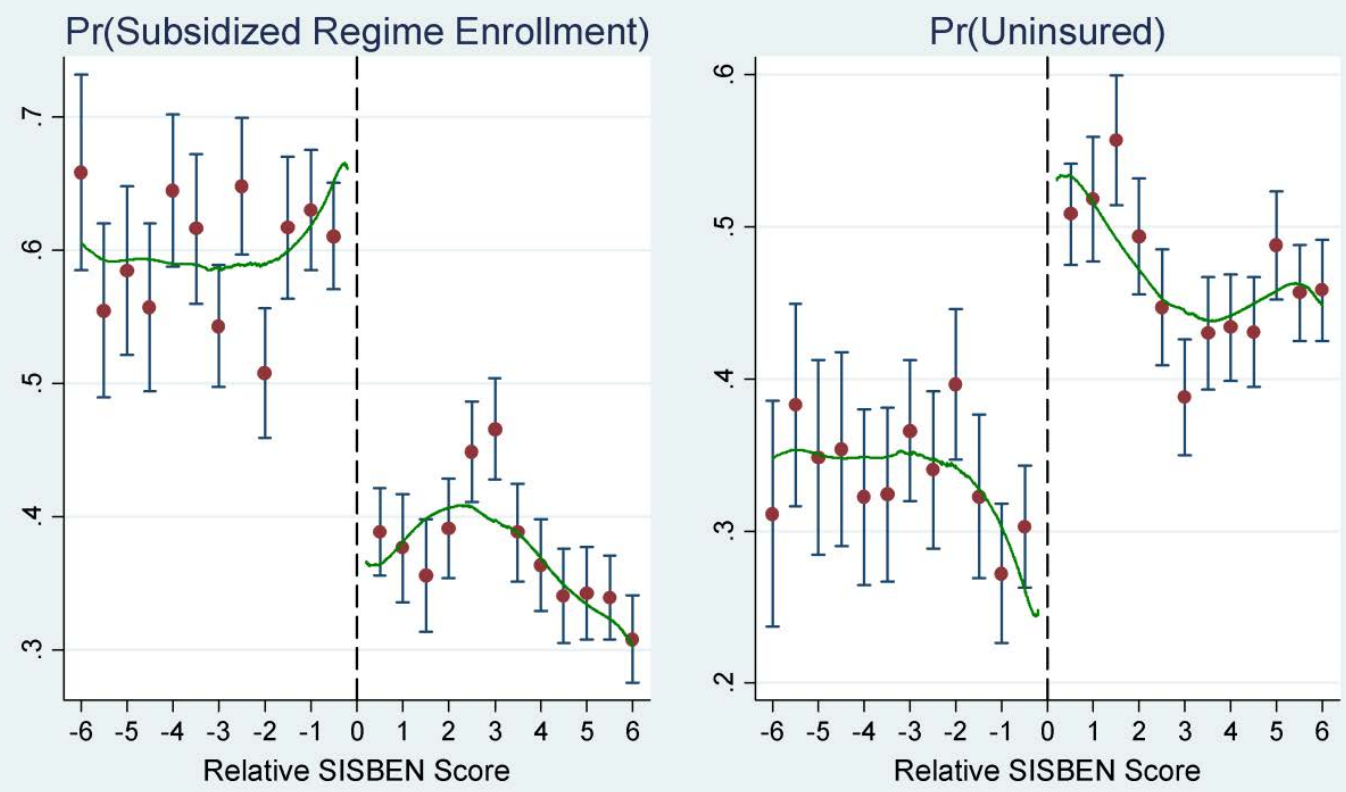

Data: ECV 2003

Figure 1B: Subsidized Regime Enrollment and 'Uninsurance' across SISBEN Eligibility Thresholds
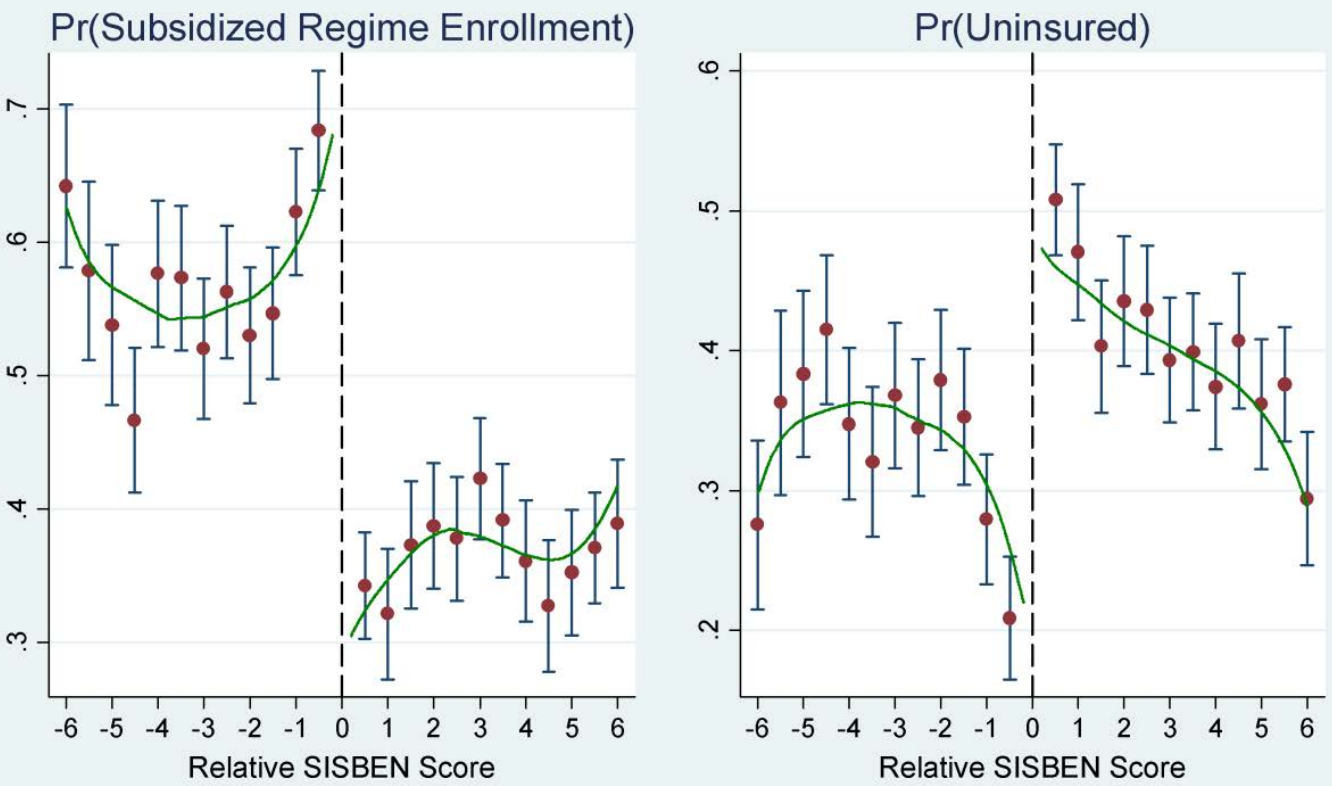

Data: DHS WOMEN 2005 


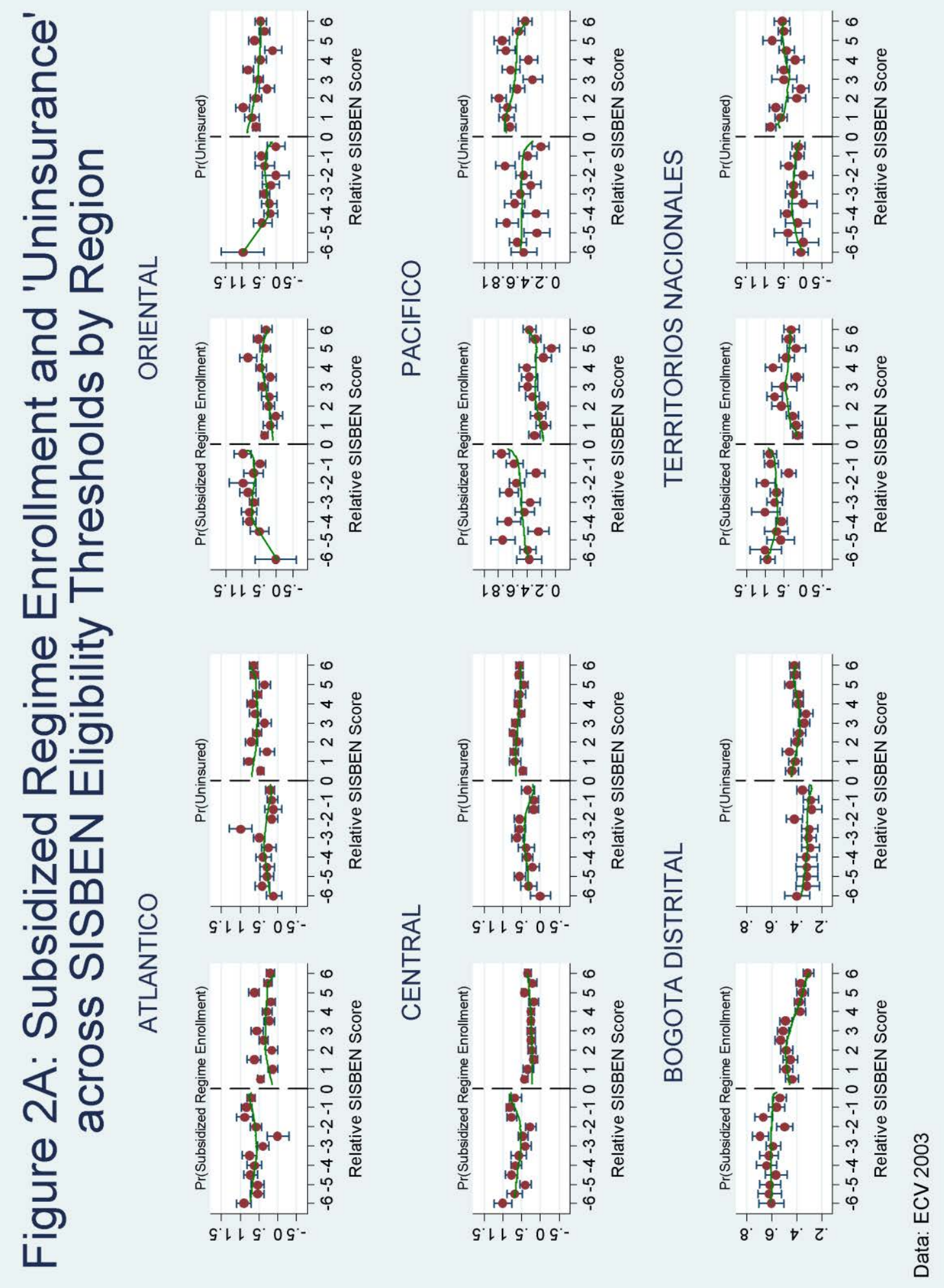




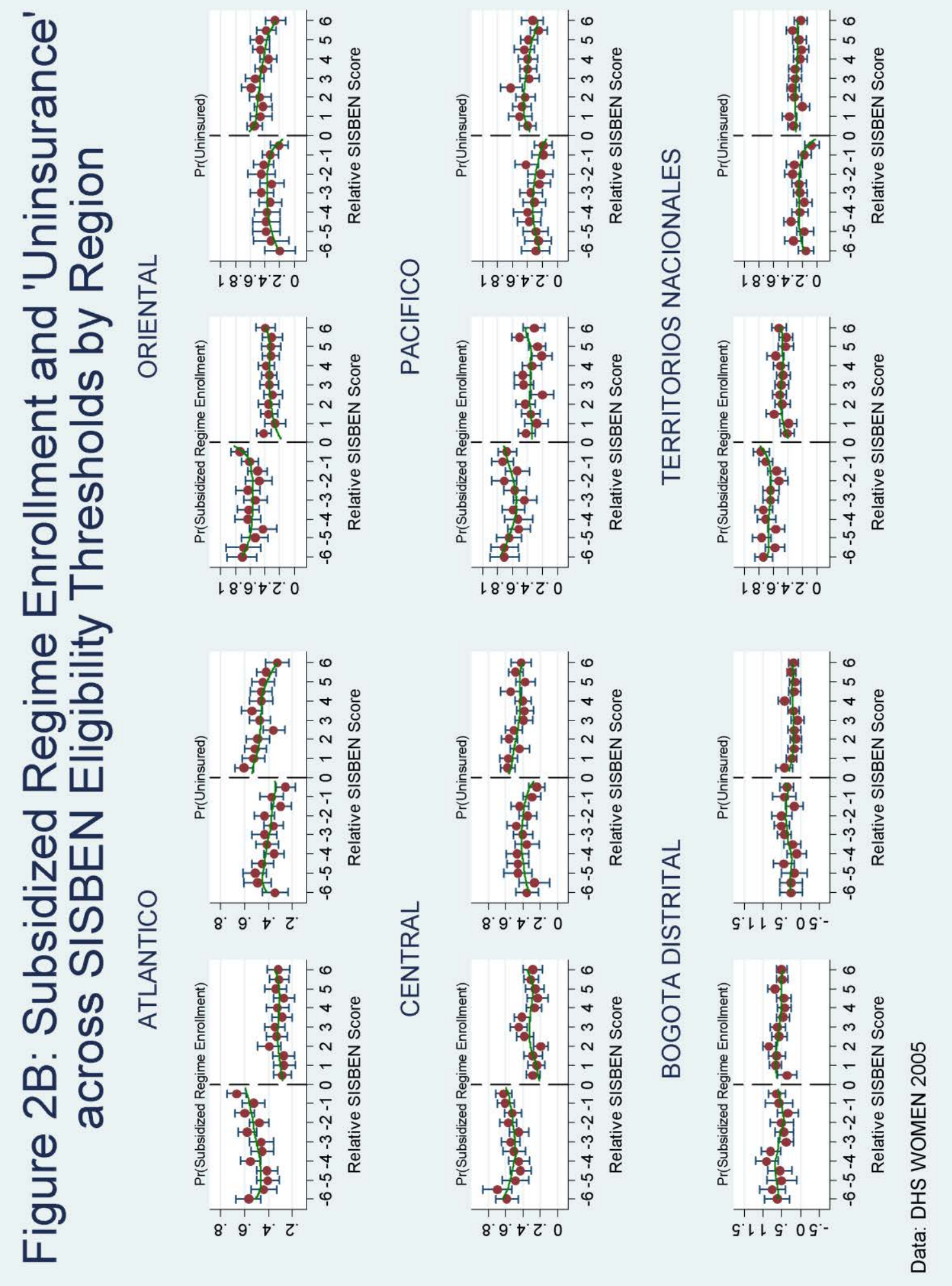


Figure 3: Individual Inpatient Medical Spending

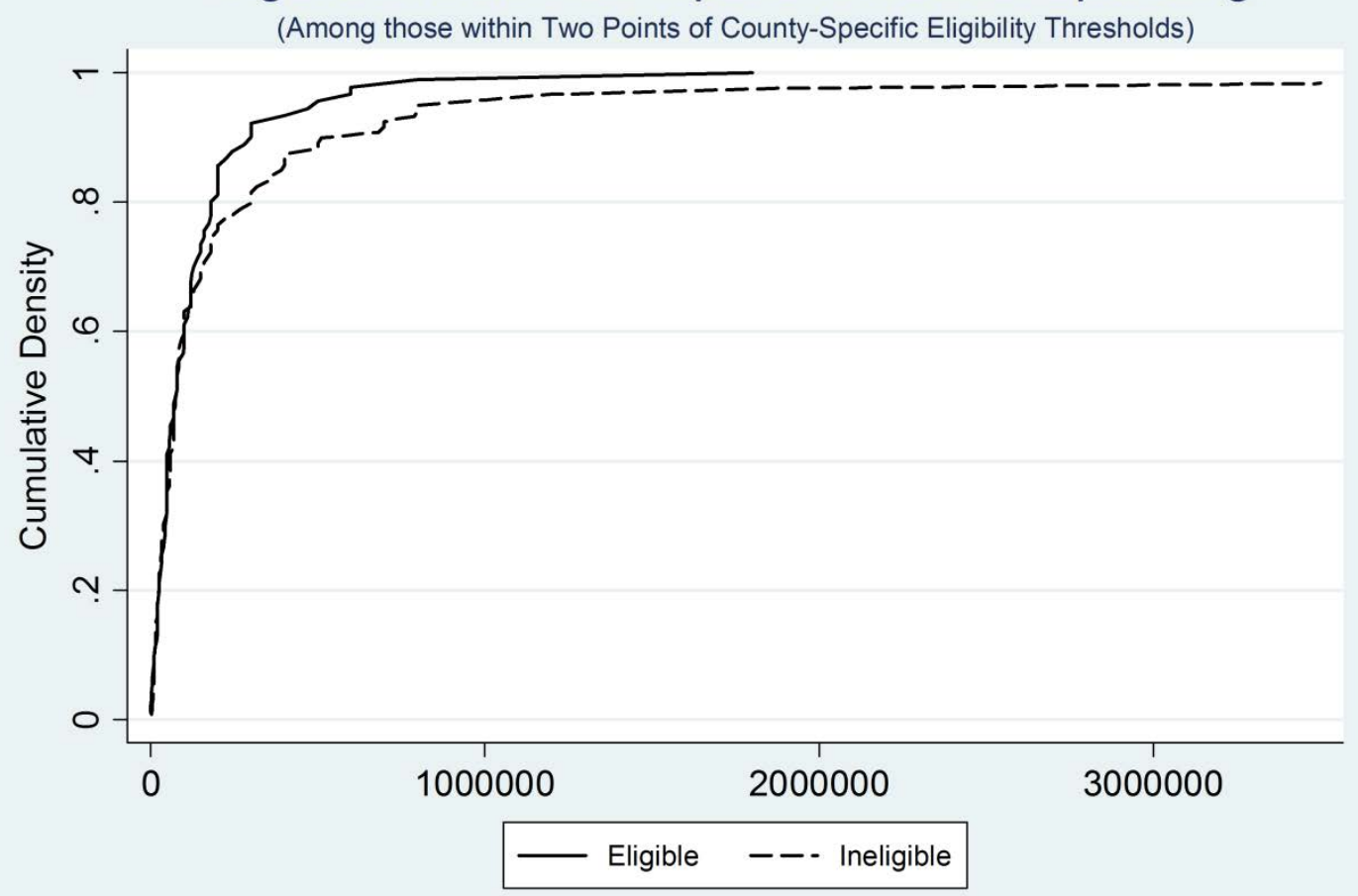

Figure 4: Individual Outpatient Medical Spending

(Among those within Two Points of County-Specific Eligibility Thresholds)

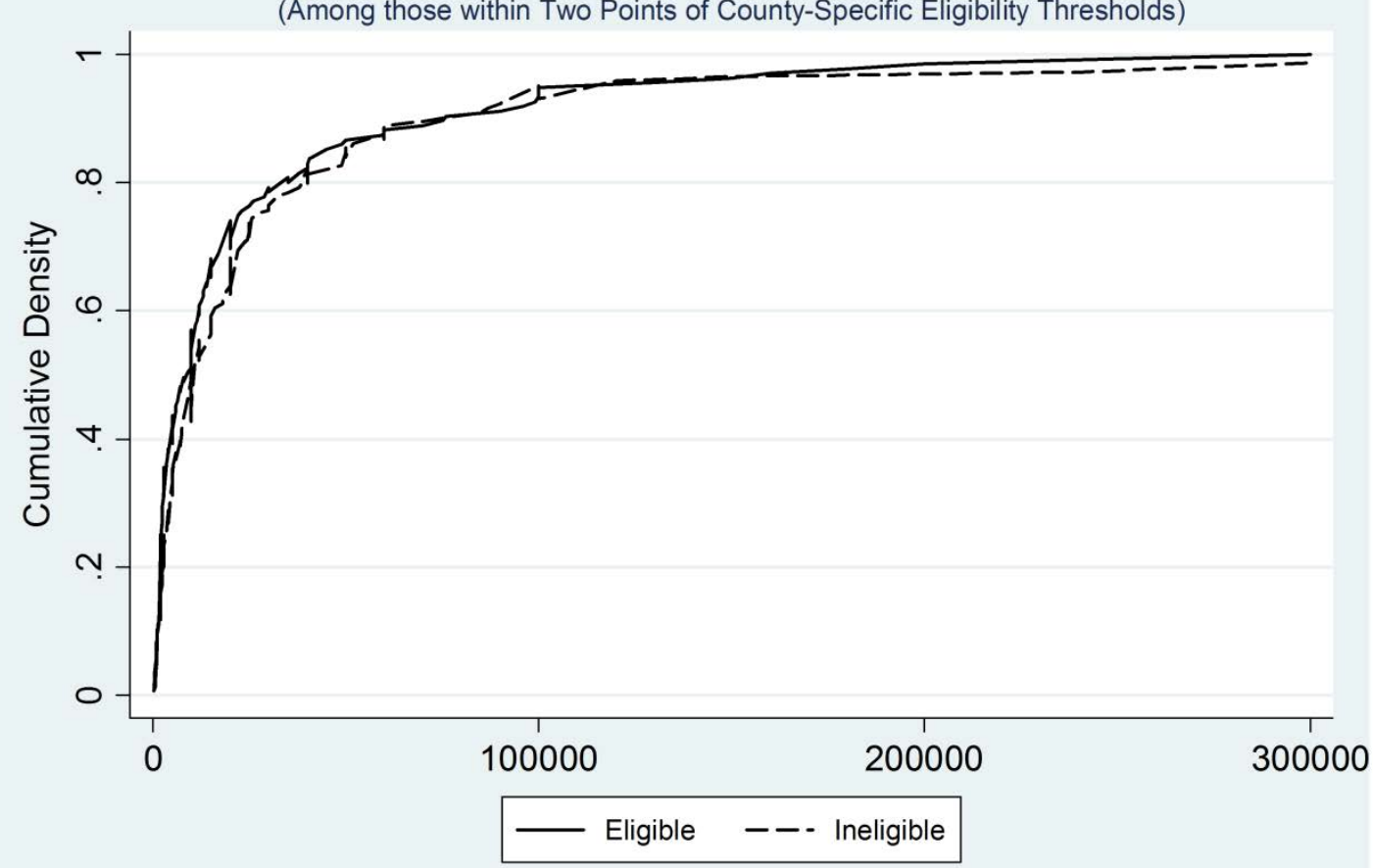









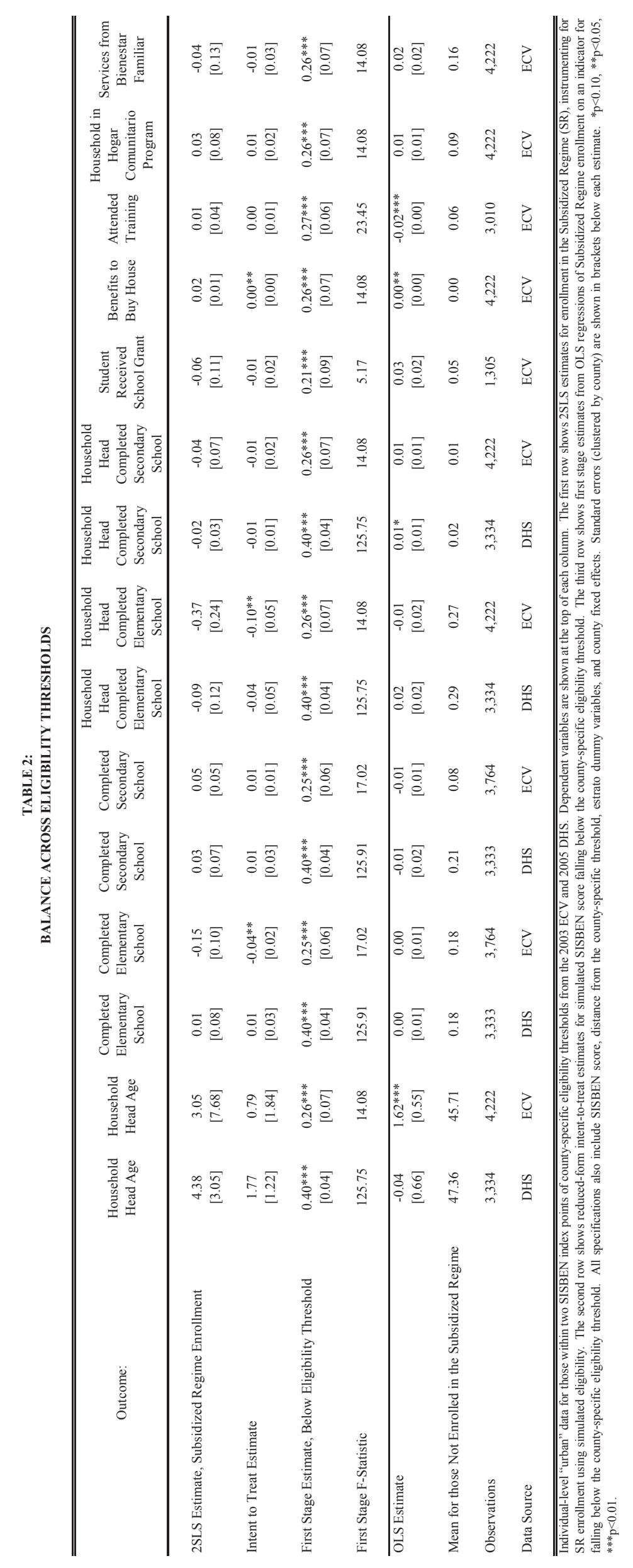


TABLE 3:

RISK PROTECTION AND PORTFOLIO CHOICE

\begin{tabular}{|c|c|c|c|c|c|c|}
\hline \multicolumn{7}{|l|}{ Panel A: Risk Protection } \\
\hline Outcome: & $\begin{array}{c}\text { Individual } \\
\text { Inpatient } \\
\text { Medical } \\
\text { Spending }\end{array}$ & $\begin{array}{c}\text { Individual } \\
\text { Outpatient } \\
\text { Medical } \\
\text { Spending }\end{array}$ & $\begin{array}{c}\text { Variability of } \\
\text { Individual } \\
\text { Inpatient } \\
\text { Medical } \\
\text { Spending }\end{array}$ & $\begin{array}{c}\text { Variability of } \\
\text { Individual } \\
\text { Outpatient } \\
\text { Medical } \\
\text { Spending } \\
\end{array}$ & & \\
\hline 2SLS Estimate, Subsidized Regime Enrollment & $\begin{array}{l}-58,870^{*} \\
{[33,263]}\end{array}$ & $\begin{array}{c}3,562 \\
{[2,702]}\end{array}$ & $\begin{array}{c}-67,499.38^{* *} \\
{[32,906]}\end{array}$ & $\begin{array}{l}167.57 \\
{[2,417]}\end{array}$ & & \\
\hline Intent to Treat Estimate & $\begin{array}{c}-15,108^{*} \\
{[8,888]}\end{array}$ & $\begin{array}{c}918.23 \\
{[821]}\end{array}$ & $\begin{array}{c}-17322.90^{*} \\
{[9,120]}\end{array}$ & $\begin{array}{l}43.20 \\
{[626]}\end{array}$ & & \\
\hline First Stage Estimate, Below Eligibility Threshold & $\begin{array}{c}0.26^{* * * *} \\
{[0.07]}\end{array}$ & $\begin{array}{c}0.26^{* * * *} \\
{[0.07]}\end{array}$ & $\begin{array}{c}0.26^{* * * *} \\
{[0.07]}\end{array}$ & $\begin{array}{c}0.26^{* * * *} \\
{[0.07]}\end{array}$ & & \\
\hline First Stage F-Statistic & 13.91 & 14.01 & 13.91 & 14.01 & & \\
\hline OLS Estimate & $\begin{array}{c}-5,655 \\
{[3,898]}\end{array}$ & $\begin{array}{c}-1,204^{* * * *} \\
{[342]}\end{array}$ & $\begin{array}{c}-13,888 * * * \\
{[3,893]}\end{array}$ & $\begin{array}{c}-4,387 * * * \\
{[357]}\end{array}$ & & \\
\hline Mean for those Not Enrolled in the Subsidized Regime & $11,359.86$ & $2,512.98$ & $263,380.40$ & $7,342.59$ & & \\
\hline Observations & 4,219 & 4,218 & 4,219 & 4,218 & & \\
\hline Data Source & ECV & $\mathrm{ECV}$ & $\mathrm{ECV}$ & ECV & & \\
\hline \multicolumn{7}{|l|}{ Panel B: Portfolio Choice } \\
\hline Outcome: & $\begin{array}{c}\text { Individual } \\
\text { Education } \\
\text { Spending } \\
\end{array}$ & $\begin{array}{c}\text { Household } \\
\text { Education } \\
\text { Spending } \\
\end{array}$ & $\begin{array}{l}\text { Total Spending } \\
\text { on Food }\end{array}$ & $\begin{array}{l}\text { Total Monthly } \\
\text { Expenditure }\end{array}$ & Has Car & Has Radio \\
\hline 2SLS Estimate, Subsidized Regime Enrollment & $\begin{array}{l}-341.68 \\
{[3,781]}\end{array}$ & $\begin{array}{c}30,366 \\
{[25,055]}\end{array}$ & $\begin{array}{c}32,136 \\
{[103,540]}\end{array}$ & $\begin{array}{c}-33,826 \\
{[278,060]}\end{array}$ & $\begin{array}{c}0.01 \\
{[0.04]}\end{array}$ & $\begin{array}{c}0.17 \\
{[0.11]}\end{array}$ \\
\hline Intent to Treat Estimate & $\begin{array}{c}-84.72 \\
{[945]}\end{array}$ & $\begin{array}{c}7,815 \\
{[4,880]}\end{array}$ & $\begin{array}{c}8,709 \\
{[28,491]}\end{array}$ & $\begin{array}{c}-14,036 \\
{[115,736]}\end{array}$ & $\begin{array}{c}0.01 \\
{[0.01]}\end{array}$ & $\begin{array}{c}0.07 \\
{[0.05]}\end{array}$ \\
\hline First Stage Estimate, Below Eligibility Threshold & $\begin{array}{c}0.25 * * * \\
{[0.06]}\end{array}$ & $\begin{array}{c}0.26 * * * \\
{[0.07]}\end{array}$ & $\begin{array}{c}0.27 * * * \\
{[0.06]}\end{array}$ & $\begin{array}{c}0.41 * * * \\
{[0.12]}\end{array}$ & $\begin{array}{c}0.40 * * * \\
{[0.04]}\end{array}$ & $\begin{array}{c}0.40 * * * \\
{[0.04]}\end{array}$ \\
\hline First Stage F-Statistic & 19.28 & 14.08 & 18.80 & 12.18 & 125.75 & 125.75 \\
\hline OLS Estimate & $\begin{array}{c}122.82 \\
{[231]}\end{array}$ & $\begin{array}{c}2,952.32 * * * \\
{[902]}\end{array}$ & $\begin{array}{c}-12,036 \\
{[10,330]}\end{array}$ & $\begin{array}{c}-39,273 \\
{[58,730]}\end{array}$ & $\begin{array}{c}-0.01 \\
{[0.01]}\end{array}$ & $\begin{array}{c}0.03 \\
{[0.02]}\end{array}$ \\
\hline Mean for those Not Enrolled in the Subsidized Regime & 7,501 & 34,089 & 279,128 & 688,065 & 0.03 & 0.60 \\
\hline Observations & 3,567 & 4,222 & 4,096 & 966 & 3,334 & 3,334 \\
\hline Data Source & ECV & $\mathrm{ECV}$ & $\mathrm{ECV}$ & $\mathrm{ECV}$ & DHS & DHS \\
\hline
\end{tabular}


TABLE 4:

USE OF PREVENTIVE MEDICAL CARE AND HEALTH STATUS

\begin{tabular}{|c|c|c|c|c|c|c|}
\hline & \multicolumn{2}{|c|}{ Use of Preventive Care } & \multicolumn{4}{|c|}{ Health Status (Children) } \\
\hline Outcome: & $\begin{array}{c}\text { Preventive } \\
\text { Physician } \\
\text { Visit }\end{array}$ & $\begin{array}{c}\text { Number of } \\
\text { Growth Dev. } \\
\text { Checks Last } \\
\text { Year }\end{array}$ & $\begin{array}{l}\text { Child Days } \\
\text { Lost to } \\
\text { Illness }\end{array}$ & $\begin{array}{l}\text { Cough, } \\
\text { Fever, } \\
\text { Diarrhea }\end{array}$ & $\begin{array}{l}\text { Any Health } \\
\text { Problem }\end{array}$ & $\begin{array}{l}\text { Birthweight } \\
\text { (KG) }\end{array}$ \\
\hline 2SLS Estimate, Subsidized Regime Enrollment & $\begin{array}{c}0.29 * * * \\
{[0.11]}\end{array}$ & $\begin{array}{l}1.50^{* *} \\
{[0.69]}\end{array}$ & $\begin{array}{c}-1.40 * * \\
{[0.65]}\end{array}$ & $\begin{array}{c}-0.18 \\
{[0.17]}\end{array}$ & $\begin{array}{c}-0.06 \\
{[0.18]}\end{array}$ & $\begin{array}{c}0.26 \\
{[0.29]}\end{array}$ \\
\hline Intent to Treat Estimate & $\begin{array}{c}0.08 * * * \\
{[0.03]}\end{array}$ & $\begin{array}{c}0.55^{* *} \\
{[0.25]}\end{array}$ & $\begin{array}{c}-0.49 * * \\
{[0.20]}\end{array}$ & $\begin{array}{c}-0.07 \\
{[0.06]}\end{array}$ & $\begin{array}{c}-0.02 \\
{[0.06]}\end{array}$ & $\begin{array}{c}0.11 \\
{[0.12]}\end{array}$ \\
\hline First Stage Estimate, Below Eligibility Threshold & $\begin{array}{c}0.26 * * * \\
{[0.07]}\end{array}$ & $\begin{array}{c}0.36^{* * *} \\
{[0.07]}\end{array}$ & $\begin{array}{c}0.35^{* * *} \\
{[0.07]}\end{array}$ & $\begin{array}{c}0.37 * * * \\
{[0.07]}\end{array}$ & $\begin{array}{c}0.35^{* * *} \\
{[0.07]}\end{array}$ & $\begin{array}{c}0.41 * * * \\
{[0.09]}\end{array}$ \\
\hline First Stage F-Statistic & 14.08 & 25.24 & 23.46 & 25.19 & 23.46 & 19.10 \\
\hline OLS Estimate & $\begin{array}{c}0.17 * * * \\
{[0.01]}\end{array}$ & $\begin{array}{c}0.33^{* * * *} \\
{[0.12]}\end{array}$ & $\begin{array}{c}-0.04 \\
{[0.17]}\end{array}$ & $\begin{array}{c}0.01 \\
{[0.04]}\end{array}$ & $\begin{array}{c}0.03 \\
{[0.04]}\end{array}$ & $\begin{array}{c}0.04 \\
{[0.05]}\end{array}$ \\
\hline Mean for those Not Enrolled in the Subsidized Regime & 0.39 & 1.00 & 0.65 & 0.56 & 0.64 & 3.25 \\
\hline Observations & 4,222 & 1,167 & 1,161 & 1,167 & 1,161 & 897 \\
\hline Data Source & $\mathrm{ECV}$ & DHS & DHS & DHS & DHS & DHS \\
\hline
\end{tabular}

Individual-level "urban" data for those within two SISBEN index points of county-specific eligibility thresholds from the 2003 ECV and 2005 DHS. Dependent variables are shown at the top of each column. The first row shows 2SLS estimates for enrollment in the Subsidized Regime (SR), instrumenting for SR enrollment using simulated eligibility. The second row shows reduced-form intent-to-treat estimates for simulated SISBEN score falling below the county specific eligibility threshold. The third row shows first stage estimates from OLS regressions of Subsidized Regime enrollment on an indicator for falling below the county-specific eligibility threshold. All specifications also include SISBEN score, distance from the county-specific threshold, estrato dummy variables, and county fixed effects. Standard errors (clustered by county) are shown in brackets below each estimate. ${ }^{*} \mathrm{p}<0.10,{ }^{*} \mathrm{p}<0.05, * * * \mathrm{p}<0.01$. 
TABLE 5:

USE OF CURATIVE MEDICAL CARE

\begin{tabular}{|c|c|c|c|c|}
\hline Outcome: & $\begin{array}{c}\text { Curative Use (Not } \\
\text { Conditonal on } \\
\text { Health Status) }\end{array}$ & $\begin{array}{c}\text { Curative Use } \\
\text { among Children } \\
\text { (Not Conditional } \\
\text { on Health Status) }\end{array}$ & $\begin{array}{l}\text { Medical Visit for } \\
\text { Chronic Disease }\end{array}$ & Hospital Stay \\
\hline 2SLS Estimate, Subsidized Regime Enrollment & $\begin{array}{l}0.13 * * \\
{[0.05]}\end{array}$ & $\begin{array}{l}-0.00 \\
{[0.16]}\end{array}$ & $\begin{array}{c}0.51 * \\
{[0.28]}\end{array}$ & $\begin{array}{l}-0.04 \\
{[0.11]}\end{array}$ \\
\hline Intent to Treat Estimate & $\begin{array}{c}0.03 * \\
{[0.02]}\end{array}$ & $\begin{array}{c}0.00 \\
{[0.06]}\end{array}$ & $\begin{array}{c}0.18 * * * \\
{[0.06]}\end{array}$ & $\begin{array}{l}-0.01 \\
{[0.03]}\end{array}$ \\
\hline First Stage Estimate, Below Eligibility Threshold & $\begin{array}{c}0.26 * * * \\
{[0.07]}\end{array}$ & $\begin{array}{c}0.35^{* * *} \\
{[0.07]}\end{array}$ & $\begin{array}{c}0.35^{* * * *} \\
{[0.10]}\end{array}$ & $\begin{array}{c}0.26 * * * \\
{[0.07]}\end{array}$ \\
\hline First Stage F-Statistic & 14.08 & 23.46 & 13.49 & 14.08 \\
\hline OLS Estimate & $\begin{array}{c}0.03 * * * \\
{[0.01]}\end{array}$ & $\begin{array}{l}0.07 * \\
{[0.04]}\end{array}$ & $\begin{array}{c}0.13^{* * *} \\
{[0.03]}\end{array}$ & $\begin{array}{l}0.02 * * \\
{[0.01]}\end{array}$ \\
\hline Mean for those Not Enrolled in the Subsidized Regime & 0.06 & 0.29 & 0.52 & 0.07 \\
\hline Observations & 4,222 & 1,161 & 564 & 4,222 \\
\hline Data Source & $\mathrm{ECV}$ & DHS & $\mathrm{ECV}$ & $\mathrm{ECV}$ \\
\hline
\end{tabular}

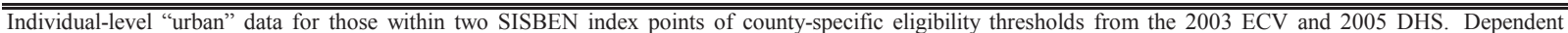
variables are shown at the top of each column. The first row shows 2SLS estimates for enrollment in the Subsidized Regime (SR), instrumenting for SR enrollment using simulated eligibility. The second row shows reduced-form intent-to-treat estimates for simulated SISBEN score falling below the county specific eligibility threshold. The third row shows first stage estimates from OLS regressions of Subsidized Regime enrollment on an indicator for falling below the county-specific eligibility threshold. All specifications also include SISBEN score, distance from the county-specific threshold, estrato dummy variables, and county fixed effects. Standard errors (clustered by county) are shown in brackets below each estimate. ${ }^{*} \mathrm{p}<0.10,{ }^{* *} \mathrm{p}<0.05,{ }^{* * *} \mathrm{p}<0.01$. 


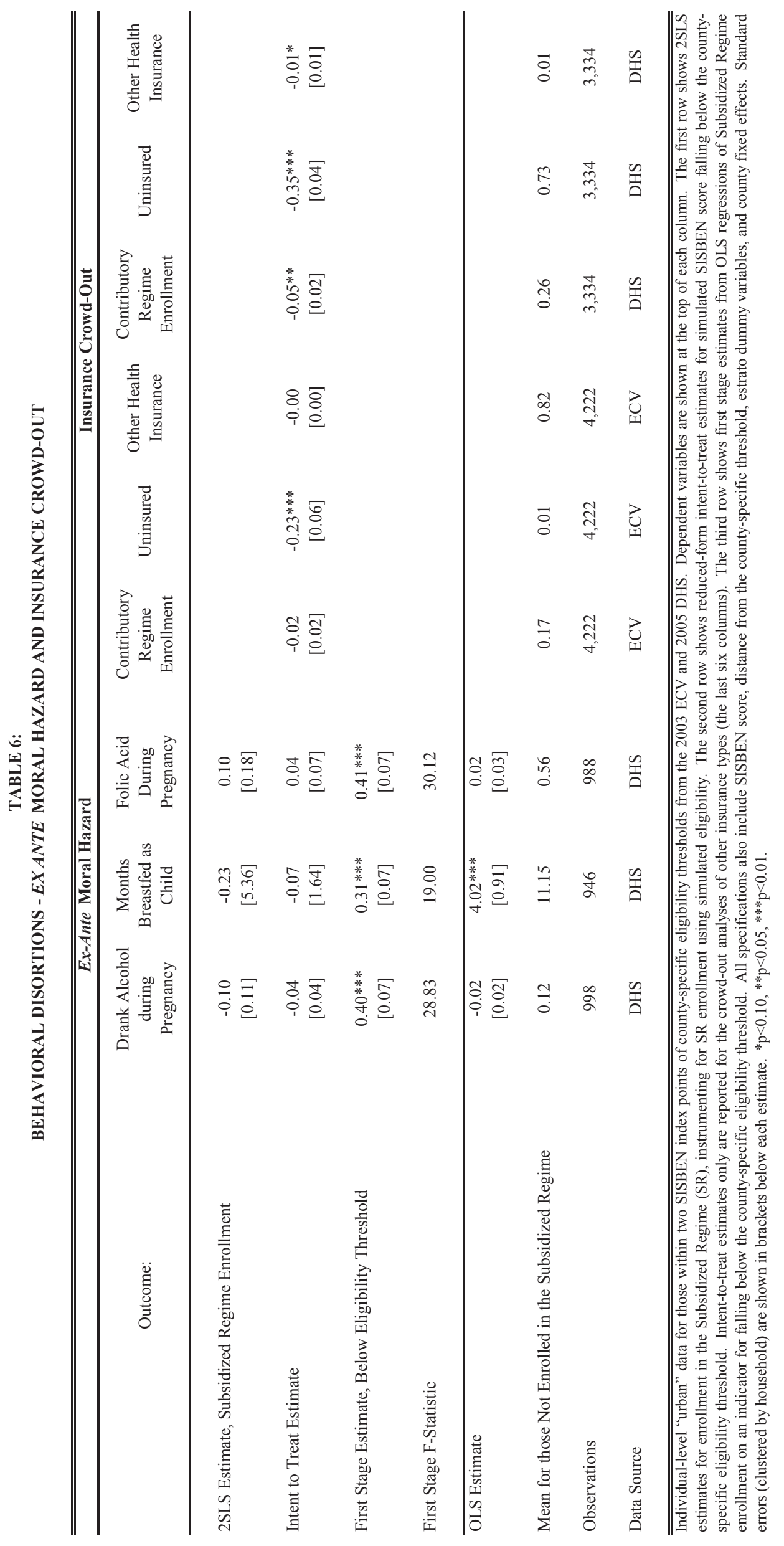


APPENDICES:

"Risk Protection, Service Use, and Health Outcomes under Colombia's Health Insurance Program for the Poor”

APPENDIX 1: Subsidized Regime Benefits

APPENDIX 2: Components of the SISBEN Index and SISBEN Score Calculations

APPENDIX 3: Sample Density by Simulated SISBEN Score

APPENDIX 4: Figures 1-4: Outcomes by SISBEN Score Relative to the Subsidized Regime Eligibility Threshold

APPENDIX 5: Tables 1-4: Robustness Analyses

APPENDIX 6: Tables 1-4: Heterogeneity Analyses 
Appendix 1: Subsidized Regime Benefits

\begin{tabular}{|c|c|c|c|c|c|c|c|c|}
\hline \multirow{2}{*}{$\begin{array}{l}\text { AGE / } \\
\text { POPULATION } \\
\text { GROUP }\end{array}$} & \multicolumn{8}{|c|}{ TYPE OF BENEFIT } \\
\hline & Preventive care & $\begin{array}{l}\text { Primary care } \\
\text { (basic } \\
\text { medical } \\
\text { consultations, } \\
\text { procedures } \\
\text { and } \\
\text { diagnostic } \\
\text { tests) }\end{array}$ & $\begin{array}{l}\text { Secondary care } \\
\text { (specialist care, } \\
\text { hospitalizations) }\end{array}$ & $\begin{array}{l}\text { Tertiary } \\
\text { care }\end{array}$ & $\begin{array}{l}\text { Catastrophic } \\
\text { care }\end{array}$ & Medications & Transportation & $\begin{array}{l}\text { Excluded } \\
\text { interventions }\end{array}$ \\
\hline$<1$ YEAR & $\begin{array}{l}\text { Neonatal care and } \\
\text { screening (Vit K, } \\
\text { anemia, TSH), } \\
\text { immunizations, well } \\
\text { child care }\end{array}$ & \multirow{6}{*}{ All } & All & All & \multirow{6}{*}{$\begin{array}{l}\text { Treatment with } \\
\text { radiotherapy } \\
\text { and } \\
\text { chemotherapy } \\
\text { for cancer, } \\
\text { dialysis and } \\
\text { organ transplant } \\
\text { for renal failure, } \\
\text { Surgical } \\
\text { treatment of } \\
\text { heart, } \\
\text { cerebrovascular, } \\
\text { neurological } \\
\text { and congenital } \\
\text { conditions, } \\
\text { treatment of } \\
\text { major trauma, } \\
\text { intensive care } \\
\text { unit, hip and } \\
\text { knee } \\
\text { replacement, } \\
\text { major burns, } \\
\text { treatment for } \\
\text { AIDS }\end{array}$} & \multirow{6}{*}{$\begin{array}{l}\text { All } \\
\text { medications } \\
\text { in national } \\
\text { formulary }\end{array}$} & \multirow{6}{*}{$\begin{array}{l}\text { For referrals, } \\
\text { catastrophic } \\
\text { care cases }\end{array}$} & \multirow{6}{*}{$\begin{array}{l}\text { Aesthetic } \\
\text { surgery } \\
\text { Infertility } \\
\text { treatment } \\
\text { Treatment for } \\
\text { sleep disorders } \\
\text { Organ } \\
\text { transplants } \\
\text { (except renal, } \\
\text { heart, chornea } \\
\text { and bone } \\
\text { marrow) } \\
\text { Psychotherapy } \\
\text { and } \\
\text { psychoanalysis } \\
\text { Treatments for } \\
\text { end stage } \\
\text { disease }\end{array}$} \\
\hline $1-4$ years & $\begin{array}{l}\text { Well child care, } \\
\text { immunizations, } \\
\text { anemia screening }\end{array}$ & & \multirow{4}{*}{$\begin{array}{l}\text { Cataract and } \\
\text { strabismus } \\
\text { surgery, } \\
\text { herniorraphy, } \\
\text { appendectomy, } \\
\text { cholecystectomy, } \\
\text { orthopedics, } \\
\text { rehabilitation } \\
\text { services and } \\
\text { procedures }\end{array}$} & \multirow{4}{*}{$\begin{array}{l}\text { Not } \\
\text { covered }\end{array}$} & & & & \\
\hline 5-19 years & $\begin{array}{l}\text { Well child care, } \\
\text { immunizations, } \\
\text { anemia screening }\end{array}$ & & & & & & & \\
\hline 20-60 years & $\begin{array}{l}\text { Cardiovascular and } \\
\text { renal disease risk } \\
\text { screening, cervical and } \\
\text { breast cancer } \\
\text { screening }\end{array}$ & & & & & & & \\
\hline$>60$ years & $\begin{array}{l}\text { Cardiovascular and } \\
\text { renal disease risk } \\
\text { screening, cervical and } \\
\text { breast cancer } \\
\text { screening }\end{array}$ & & & & & & & \\
\hline $\begin{array}{l}\text { PREGNANT } \\
\text { WOMEN }\end{array}$ & $\begin{array}{l}\text { High risk screening, } \\
\text { STD, prenatal care }\end{array}$ & & $\begin{array}{l}\text { Same as above } \\
\text { plus obstetric } \\
\text { care }\end{array}$ & $\begin{array}{l}\text { Obstetric } \\
\text { care }\end{array}$ & & & & \\
\hline
\end{tabular}




\section{Appendix 2: Components of the SISBEN Index and SISBEN Score Calculations}

This appendix describes the components of SISBEN index, details the index information available in each household survey, and explains how we calculate SISBEN scores in each data source.

\section{Components of the SISBEN Index}

As explained in the text of the paper, our study focuses on the original urban SISBEN index There are four general types of information used in calculating the SISBEN index: (A) human capital, employer characteristics, and benefits; (B) demographics, income, and labor force participation; (C) housing characteristics; and (D) access to public utilities. The index is composed of 14 components across these categories. For each component, respondents are categorized according to mutually exclusive, collectively exhaustive polychotomous response categories. Each response category for each component corresponds to a weight or "points," and index scores are calculated by summing across points. Scores range between 0 and 100; higher scores denote higher socio-economic status.

The specific components of the index are:

\section{(A) Human Capital; Employer Characteristics and Benefits}

- (1) Educational attainment of the household head

- (2) Mean Schooling for household members twelve years old and older

- (3) Firm size and provision of Social Security benefits for the household head

(B) Demographics, Income, and Labor Force Participation

- (4) Proportion of children six years old and under (as share of children under age eighteen)

- (5) Proportion of household members employed (as a share of those older than twelve)

- (6) Per capita income indexed to the minimum wage (all types of income are counted)

\section{(C) Housing Characteristics}

- (7) Number of rooms per person

- (8) Primary wall material

- (9) Primary roof material

- (10) Primary floor material

- (11) Number of appliances (among those on a pre-determined list)

(D) Access to Public Utilities

- (12) Water source

- (13) Sewage disposal

- (14) Garbage disposal

\section{SISBEN Components Available in Each Household Survey}

Our analyses use the 2003 ECV and the 2005 DHS. The table below shows which SISBEN components are available in each survey. 


\begin{tabular}{|c|c|c|}
\hline Variable & DHS 2005 & ECV 2003 \\
\hline Educational Attainment & Available & Available \\
\hline Employment Status & Available & Available \\
\hline \multicolumn{3}{|l|}{ Social Security Benefits } \\
\hline Health Insurance & Available & Available \\
\hline Pension & Not Available & Available \\
\hline Firm Size (Number of Employees) & Not Available & Available \\
\hline Age & Available & Available \\
\hline Income & Not available & Available \\
\hline Number of Rooms & Available & Available \\
\hline Primary Wall Material & Available & Available \\
\hline Primary Roof Material & Not available & Not available \\
\hline Primary Floor Material & Available & Available \\
\hline \multicolumn{3}{|l|}{ Number of Appliances } \\
\hline TV & Available & Available \\
\hline Refrigerator & Available & Available \\
\hline Air Conditioner & Available & Available \\
\hline Blender & Available & Available \\
\hline Washing Machine & Available & Available \\
\hline Water Source & Available & Available \\
\hline Sewage Disposal & Available & Available \\
\hline Garbage Disposal & Available & Available \\
\hline
\end{tabular}

Most SISBEN components are available in the household surveys we use in our primary analyses (nearly all in the $2003 \mathrm{ECV}$ and the great majority in the $2005 \mathrm{DHS}$ ). For missing components, we use an ordered probit procedure to predict the most likely response category for each missing component using a large number of observable household characteristics. The section below describes how we performed our SISBEN score calculations.

\section{SISBEN Score Calculations}

In this section we report SISBEN index weights for each response category for each component and describe how we impute scores for components not represented in our household surveys. SISBEN index scores are then calculated by summing weights or points across all components.

\section{A. Human Capital; Employer Characteristics and Benefits}

\section{Educational attainment of the household head}

\begin{tabular}{|l|l|l|}
\hline 1 & No education & 0 \\
\hline 2 & Some elementary & 1.6239 \\
\hline 3 & Complete elementary & 3.4435 \\
\hline 4 & Some secondary & 5.0039 \\
\hline 5 & Complete secondary & 7.3434 \\
\hline 6 & Some of higher education & 9.7833 \\
\hline 7 & Complete higher education & 11.546 \\
\hline 8 & Graduate studies & 12.4806 \\
\hline
\end{tabular}


To compute educational attainment, we use information of level of schooling completed and number of years of schooling. Levels of schooling correspond to the following number of years of education:

- Complete elementary school: 5 years

- Complete secondary education: 11 years

- Complete higher education: 16 years

- Graduate studies: 16 or more years

Sufficient information on level and years of schooling is available to compute this variable in all household surveys.

2. Mean Schooling for household members twelve years old and older

\begin{tabular}{|l|l|l|}
\hline 1 & 0 years & 0 \\
\hline 2 & Between 0 and 4 years & 1.657 \\
\hline 3 & Between 4 and 5 years & 2.9947 \\
\hline 4 & Between 5 and 10 years & 4.969 \\
\hline 5 & Between 10 and 11 years & 7.6387 \\
\hline 6 & Between 11 and 15 years & 9.4425 \\
\hline 7 & Between 15 and 16 years & 10.69 \\
\hline 8 & 16 years or more & 11.1396 \\
\hline
\end{tabular}

Using the coding scheme described for calculating educational attainment for the household head, we calculate mean years of schooling for all household members 12 and older. Sufficient information is available to compute this variable in all household surveys.

\section{Firm size and provision of Social Security benefits for the household head}

\begin{tabular}{|l|l|l|}
\hline 1 & $\begin{array}{l}\text { Without benefits and either works alone or does not } \\
\text { work }\end{array}$ & 0 \\
\hline 2 & $\begin{array}{l}\text { Without benefits and works in firm with 2 to 9 } \\
\text { employees }\end{array}$ & 1.166 \\
\hline 3 & $\begin{array}{l}\text { Without benefits and works in firm with 10 or more } \\
\text { employees }\end{array}$ & 2.6545 \\
\hline 4 & $\begin{array}{l}\text { With benefits and either works alone or does not } \\
\text { work }\end{array}$ & 3.9539 \\
\hline 5 & $\begin{array}{l}\text { Without benefits and works in firm with 2 to 9 } \\
\text { employees }\end{array}$ & 5.8427 \\
\hline 6 & $\begin{array}{l}\text { Without benefits and works in firm with 10 or more } \\
\text { employees }\end{array}$ & 6.9718 \\
\hline
\end{tabular}

Assigning response categories for this index component requires information about employment status, social security benefits (health insurance and pension benefits), and firm size:

- Employment status is available in all household surveys.

- Firm size is not available in the 2005 DHS. We therefore use ordered probit models to predict the probability of falling into each of the three firm size categories ( 1 employee, 2-9 employees, 10 or more employees). We then select the category with the highest predicted probability. To obtain parametric estimates of the relationship between a variety of observable household characteristics (demographic characteristics, education, 
and regional controls among urban residents) and firm size, we estimate these ordered probit models using the $2003 \mathrm{ECV}$

- Social Security benefits consist of two components: health insurance benefits and pension benefits:

- Health Insurance Benefits. Health insurance status is judged in each household survey in the following way:

ECV 2003: Has health insurance if affiliated with "ISS," "Caja de Prevision," "army/police" insurance scheme, "Ecopetrol" scheme, the "educational system" scheme, or an "EPS - different to ISS or Caja de Prevision." Those with insurance through an "ARS" or "Empresa solidaria" are excluded.

DHS 2005: Has health insurance if affiliated with "ISS," "EPS," "Public

Agency," "army/police" insurance scheme, "Ecopetrol" scheme, the "educational system"scheme, or "Foncolpuertos." Those with insurance through an "ARS" are excluded.

- Pension Benefits. Pension benefits are judged according to affiliation with the public or private pension system. This information is available in the $2003 \mathrm{ECV}$ but not in the 2005 DHS.

In the $2003 \mathrm{ECV}$, Social Security benefits are judged according to having health insurance and/or pension benefits. In the 2005 DHS, Social Security benefits are judged according to health insurance benefits.

(B) Demographics, Income, and Labor Force Participation

(4) Proportion of children six years old and under (as share of children under age eighteen)

\begin{tabular}{|l|l|l|}
\hline 1 & Greater than 0.65 & 0 \\
\hline 2 & From 0 to 0.65 & 0.2237 \\
\hline 3 & Zero & 1.4761 \\
\hline
\end{tabular}

Sufficient information is available to compute this variable in all household surveys.

(5) Proportion of household members employed (as a share of those older than twelve)

\begin{tabular}{|l|l|l|}
\hline 1 & Less than 0.30 & 0 \\
\hline 2 & From 0.30 to 0.60 & 0.6717 \\
\hline 3 & From 0.60 to 0.90 & 1.739 \\
\hline 4 & Greater than 0.90 & 4.0149 \\
\hline
\end{tabular}

For constructing this proportion, employment is defined as having worked in the preceding week, not having worked but having regular job, or receiving payment for working more than one hour. Sufficient information is available to compute this variable in all household surveys. 
(6) Per capita income indexed to the minimum wage (all types of income are counted)

\begin{tabular}{|l|l|l|}
\hline 1 & Up to 0.15 & 0 \\
\hline 2 & Above 0.15 up to 0.25 & 0.8476 \\
\hline 3 & Above 0.25 up to 0.35 & 2.1828 \\
\hline 4 & Above 0.35 up to 0.50 & 3.5362 \\
\hline 5 & Above 0.50 up to 0.75 & 5.3636 \\
\hline 6 & Above 0.75 up to 1.00 & 7.0827 \\
\hline 7 & Above 1.00 up to 1.25 & 8.2489 \\
\hline 8 & Above 1.25 up to 1.50 & 9.4853 \\
\hline 9 & Above 1.50 up to 2.00 & 10.2098 \\
\hline 10 & Above 2.00 up to 3.00 & 11.3999 \\
\hline 11 & Above 3.00 up to 4.00 & 13.0872 \\
\hline 12 & Above 4.00 & 13.7378 \\
\hline
\end{tabular}

To calculate per capita income for a family, we define income to include labor income from primary and secondary jobs (both for the employed and self-employed) and pension benefits for retirees. In-kind subsides are excluded. We obtained nominal minimum wage information (summarized below) from The Colombian Central Bank's Monetary and Financial Statistics:

\begin{tabular}{|l|l|}
\hline Year & $\begin{array}{l}\text { Minimum wage (in } \\
\text { Colombian pesos) }\end{array}$ \\
\hline 2003 & $332,000.0$ \\
\hline 2005 & $381,500.0$ \\
\hline
\end{tabular}

Income variables are available only in the $2003 \mathrm{ECV}$. For the 2005 DHS, we use ordered probit models to predict the probability of falling into each of 12 discrete categories; we then select the category with the highest predicted probability. To obtain parametric estimates of the relationship between a variety of observable household characteristics (demographic characteristics, education, and regional controls among urban residents) and firm size, we estimate these ordered probit models using the $2003 \mathrm{ECV}$.

\section{(C) Housing Characteristics}

\section{(7) Number of rooms per person}

\begin{tabular}{|l|l|l|}
\hline 1 & Less than 0.20 & 0 \\
\hline 2 & 0.20 to 0.30 & 0.5584 \\
\hline 3 & 0.30 to 0.40 & 1.6535 \\
\hline 4 & 0.40 to 0.70 & 2.5727 \\
\hline 5 & 0.70 to 1.00 & 4.3886 \\
\hline 6 & 1.00 to 4.00 & 6.0042 \\
\hline 7 & Greater than 4.00 & 8.3828 \\
\hline
\end{tabular}

To assign response categories for this index component, rooms are defined as rooms exclusively used by household members (including living rooms but excluding kitchens, bathrooms, garages, and rooms used for business). This information is available in the 2003 ECV. For the 2005 DHS, we use number of rooms used by household members for sleeping. 
(8) Primary wall material

\begin{tabular}{|l|l|l|}
\hline 1 & Without walls or with bamboo or other organic materials & 0 \\
\hline 2 & Zinc, cloth, cardboard, cans & 0.2473 \\
\hline 3 & Raw wood & 2.0207 \\
\hline 4 & Mud and cane wall & 4.8586 \\
\hline 5 & Adobe, wide mud wall & 6.2845 \\
\hline 6 & Block, bricks, stone, prefabricated material, polished wood & 7.7321 \\
\hline
\end{tabular}

Information on wall material is available in both the $2003 \mathrm{ECV}$ and the 2005 DHS.

(9) Primary roof material

\begin{tabular}{|l|l|l|}
\hline 1 & Straw or palm leaves & 0 \\
\hline 2 & $\begin{array}{l}\text { Recycled household materials (cardboard, cans, } \\
\text { burlap sacks, etc) }\end{array}$ & 2.1043 \\
\hline 3 & Zinc, asbestos, cement, without ceiling & 3.7779 \\
\hline 4 & Clay tile, zinc, asbestos, cement, with ceiling & 5.0973 \\
\hline
\end{tabular}

Information on primary roof material is available only in the $1997 \mathrm{ECV}$. We therefore use parametric estimates of the relationship between observable characteristics (number of rooms, floor material and regional dummies among urban households) and roof material obtained from an ordered probit model fit with the $1997 \mathrm{ECV}$ to predict the probability of falling into each roof material category shown above. We assign the category with the highest predicted probability.

(10) Primary floor material

\begin{tabular}{|l|l|l|}
\hline 1 & Dirt & 0 \\
\hline 2 & Raw wood, boards & 2.9037 \\
\hline 3 & Cement & 3.6967 \\
\hline 4 & Floor tile (clay, vinyl), brick or paving tile & 5.8712 \\
\hline 5 & Wall to wall carpet, marble, polished wood & 6.8915 \\
\hline
\end{tabular}

Sufficient information is available to compute this variable in all household surveys.

(11) Number of appliances (among those on a pre-determined list)

\begin{tabular}{|l|l|l|}
\hline 1 & No appliances & 0 \\
\hline 2 & 1 -3 basic appliances basics & 2.1435 \\
\hline 3 & 4 basic appliances without laundry machine & 3.0763 \\
\hline 4 & 3 or more basic appliances with laundry machine & 4.7194 \\
\hline
\end{tabular}

For this SISBEN index component, four appliances are considered "basic" (TVs, refrigerators, blenders, and air conditioners) and a washing/laundry machine is treated separately as shown in the table above. All necessary information about appliances is present in both the $2003 \mathrm{ECV}$ and the 2005 DHS. 


\section{(D) Access to Public Utilities}

(12) Water source

\begin{tabular}{|l|l|l|}
\hline 1 & River or spring & 0 \\
\hline 2 & Public fountain or other source & 1.1606 \\
\hline 3 & Well without water pump, container or rain water & 2.6497 \\
\hline 4 & Well with water pump & 4.6037 \\
\hline 5 & Container truck & 6.1693 \\
\hline 6 & Aqueduct & 7.2554 \\
\hline
\end{tabular}

All necessary information for assigning response categories is available in the $2003 \mathrm{ECV}$. In the 2005 DHS, we classify "bottled water" as "aqueduct."

\section{(13) Sewage disposal}

\begin{tabular}{|l|l|l|}
\hline 1 & No sewage & 0 \\
\hline 2 & Latrine & 2.4519 \\
\hline 3 & Toilet without connection to sewer or septic tank & 3.3323 \\
\hline 4 & Toilet with connection to septic tank & 3.9615 \\
\hline 5 & Toilet with connection to sewer & 6.8306 \\
\hline
\end{tabular}

Information on sewage disposal is available in all household surveys, but in the 2005 DHS, some minor coding assumptions were necessary. In the 2005 DHS, we code both "traditional pit toilet" and "traditional toilet to sea/river" as "latrine."

\section{(14) Garbage disposal}

\begin{tabular}{|l|l|l|}
\hline 1 & Yard, lot, river, etc. & 0 \\
\hline 2 & Local container or public trashcan & 2.1291 \\
\hline 3 & Picked up by public services & 3.2701 \\
\hline
\end{tabular}

Information on garbage disposal is available in both the 2005 DHS and the $2003 \mathrm{ECV}$. 


\section{Appendix 3: Sample Density by Simulated SISBEN Score}

The figure in this appendix plots histograms of simulated SISBEN scores relative to county-specific eligibility thresholds. Using the ECV 2003, density in the distribution of relative SISBEN scores evolves smoothly across local thresholds. There are some spikes in density at other scores $\left(-3,5\right.$, and 7 for example) that we presume to be idiosyncratic noise. ${ }^{1}$ In the DHS 2005, we observe similar spikes, but one of them coincides with relative score -1. The magnitude is comparable to those at other scores (4 and 8, for example) as well as spikes in the ECV 2003. Given balance on observable characteristics across the eligibility threshold (shown in Table 2) as well as the fact that county-specific thresholds were not stipulated or even known ex ante, we believe that it is unlikely that simulated SISBEN scores are manipulated. We also predict values for more index components when constructing simulated scores in the DHS 2005 than in the ECV 2003. ${ }^{2}$

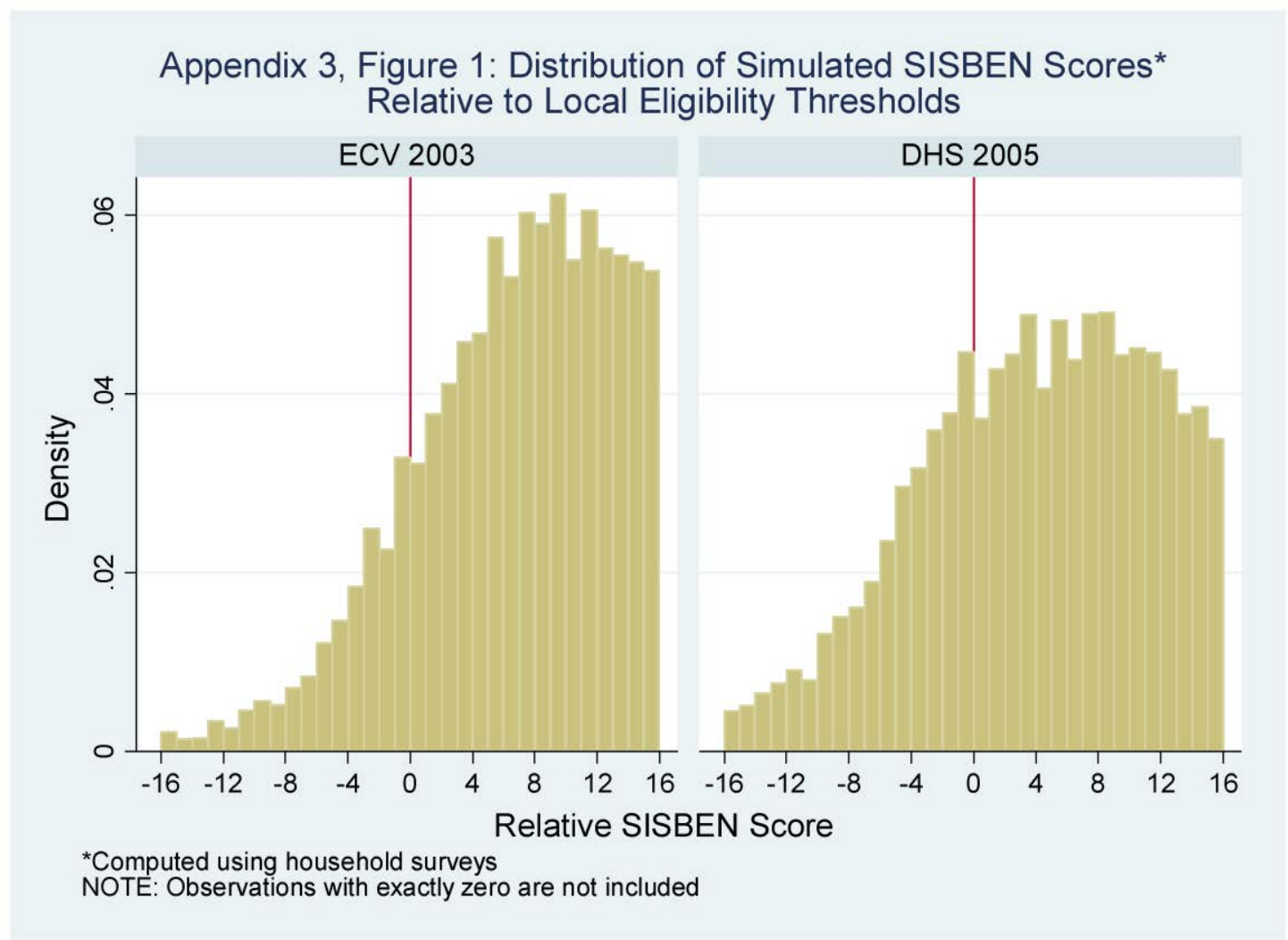

\footnotetext{
${ }^{1}$ We omit observations with values of exactly zero because our estimation of county-specific eligibility thresholds (producing the best fit between eligibility and actual insurance coverage (Chay, McEwan, and Urquiola 2005)) mechanically yields differential density.

${ }^{2}$ In the 2005 DHS, we predict values for two SISBEN components: firm size and per-capita income (variables measuring these components are available in the $2003 \mathrm{ECV}$ ). Additionally, response categories in the 2005 DHS are coarser for four other SISBEN components: social security, number of rooms, water source, and sewage disposal. See Appendix 2 for more details.
} 


\section{Appendix 4, Figure 1: Risk Protection, Consumption Smoothing, and Portfolio Choice}
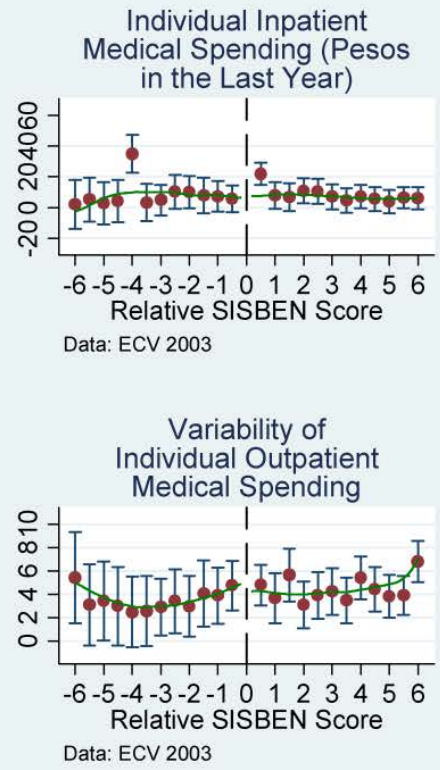

Total Monthly Spending
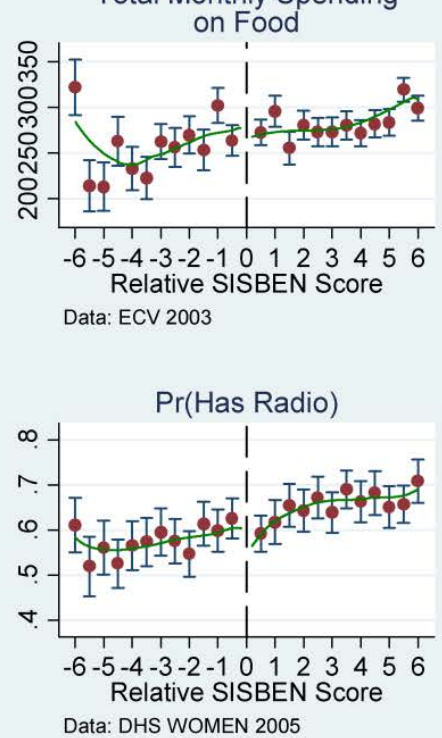

Individual Outpatient Medical Spending (Pesos in the Last Month)

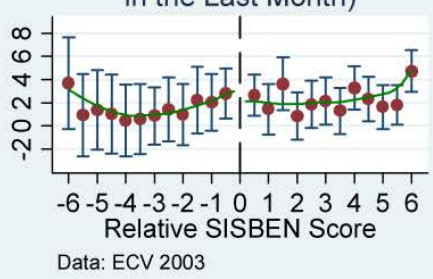

Individual Education Spending (Pesos in the Last Month)
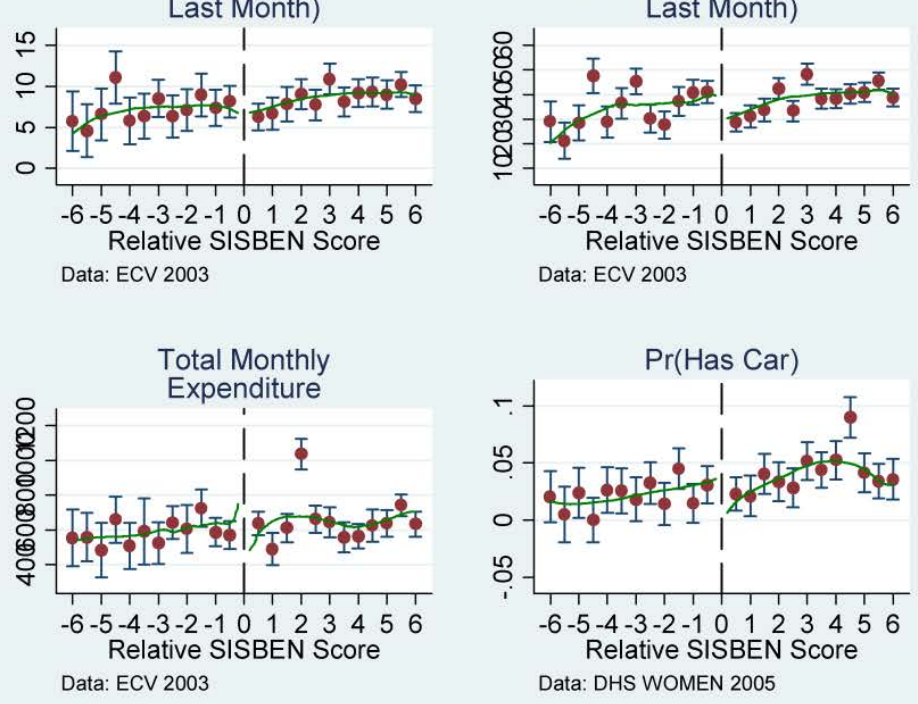


\section{Appendix 4, Figure 2: Use of Preventive Care and Health Status}

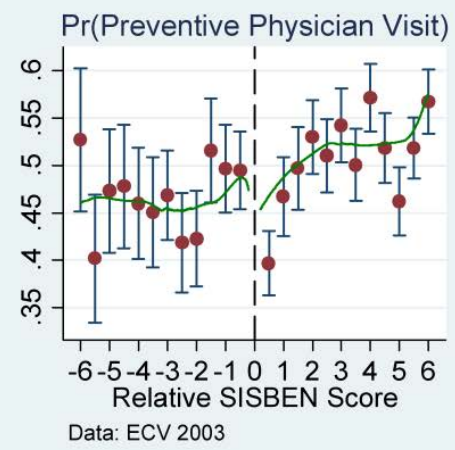

$\operatorname{Pr}($ Cough Fever Diarrhea)

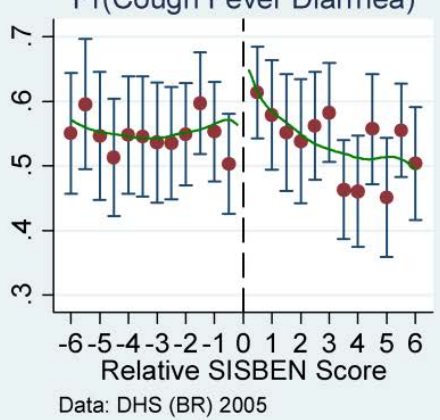

Number of Growth Dev. Checks Last Year

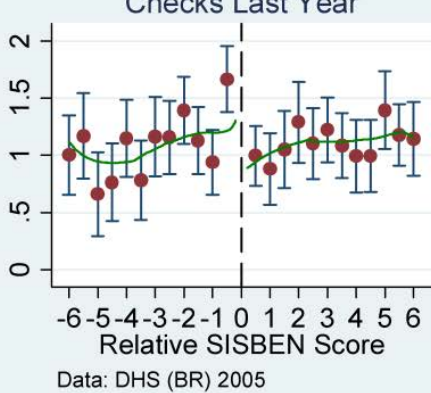

Data: DHS (BR) 2005

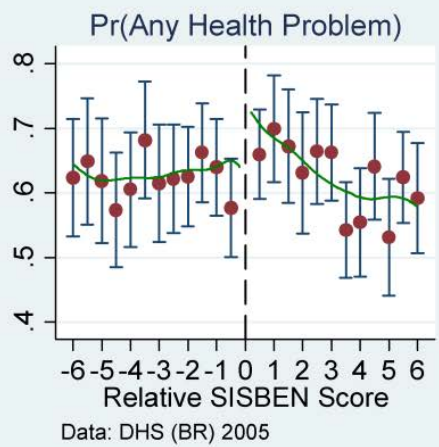

Child Days Lost to Illness

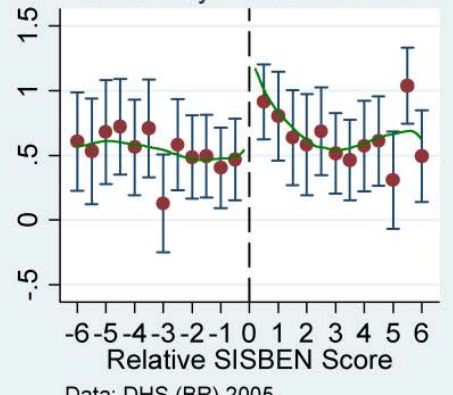

Data: DHS (BR) 2005

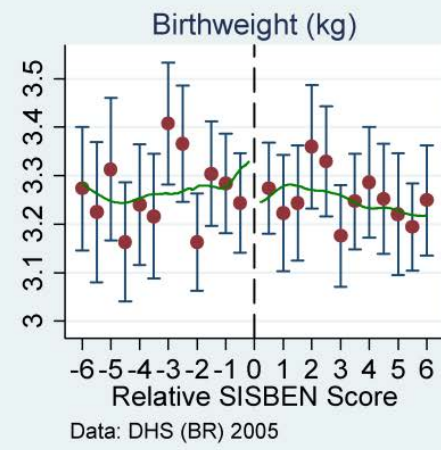




\section{Appendix 4, Figure 3: Use of Curative Care}

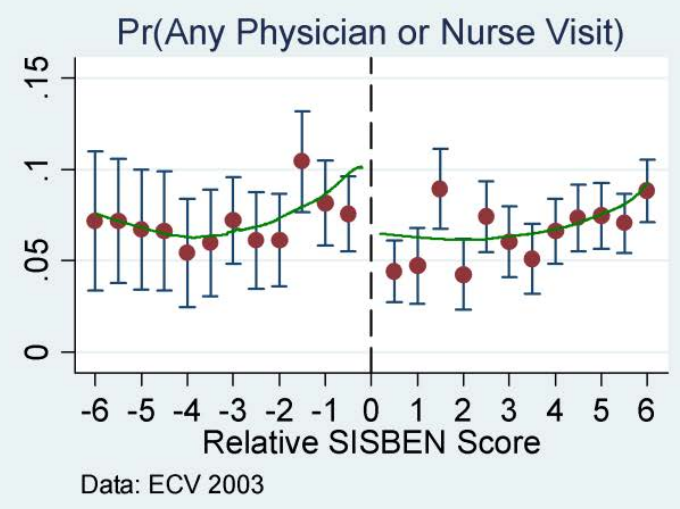

$\operatorname{Pr}$ (Curative use among
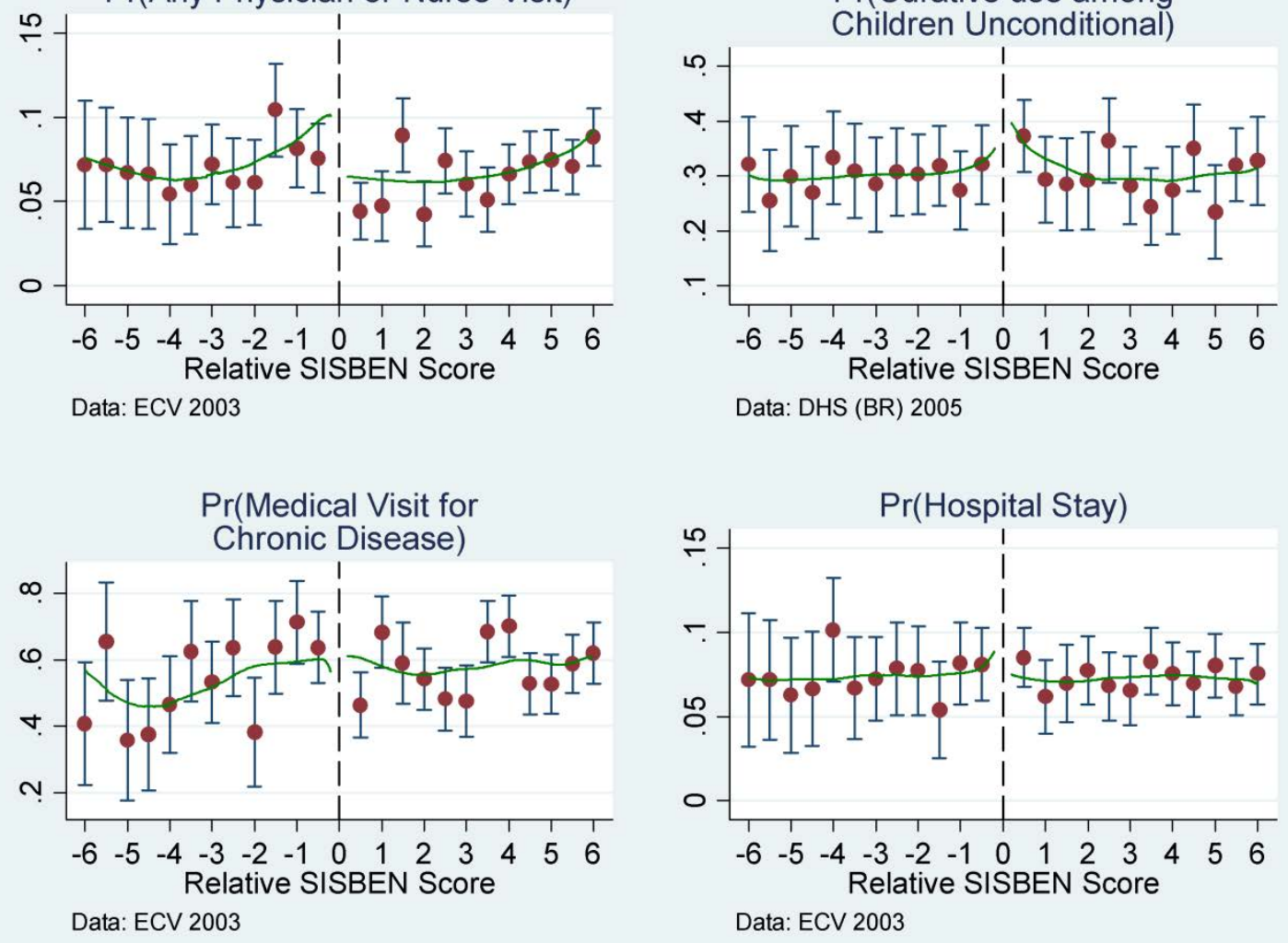


\section{Appendix 4, Figure 4: Behavioral Distortions}
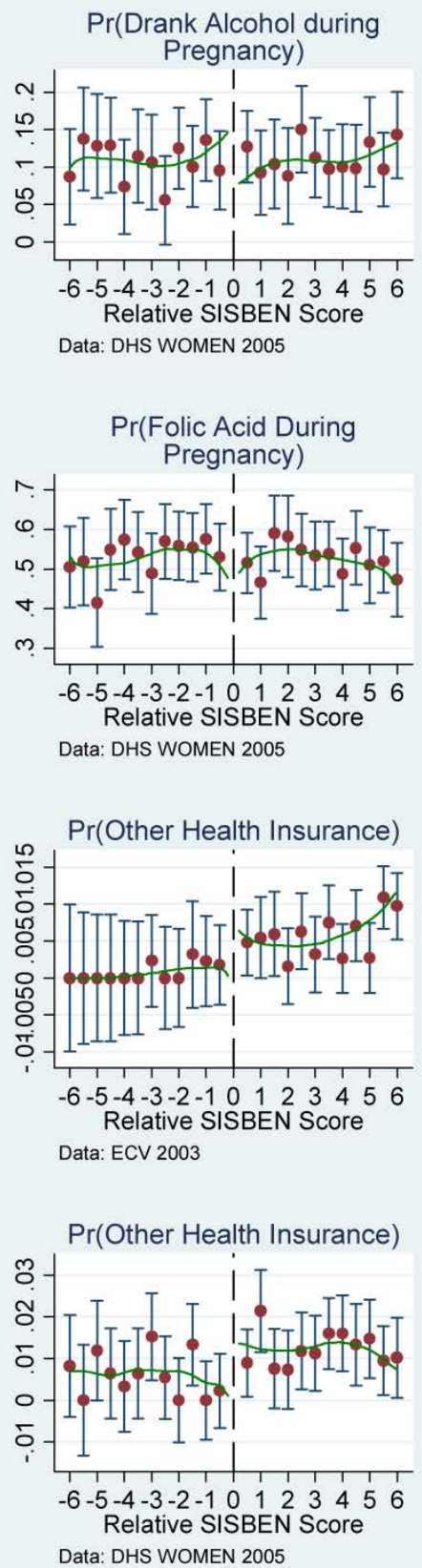
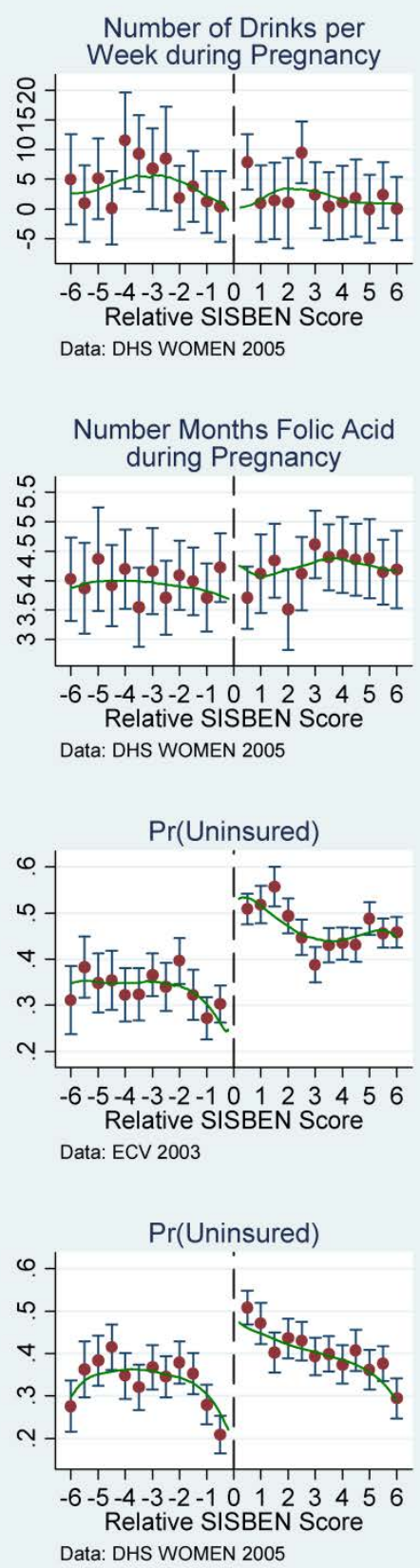
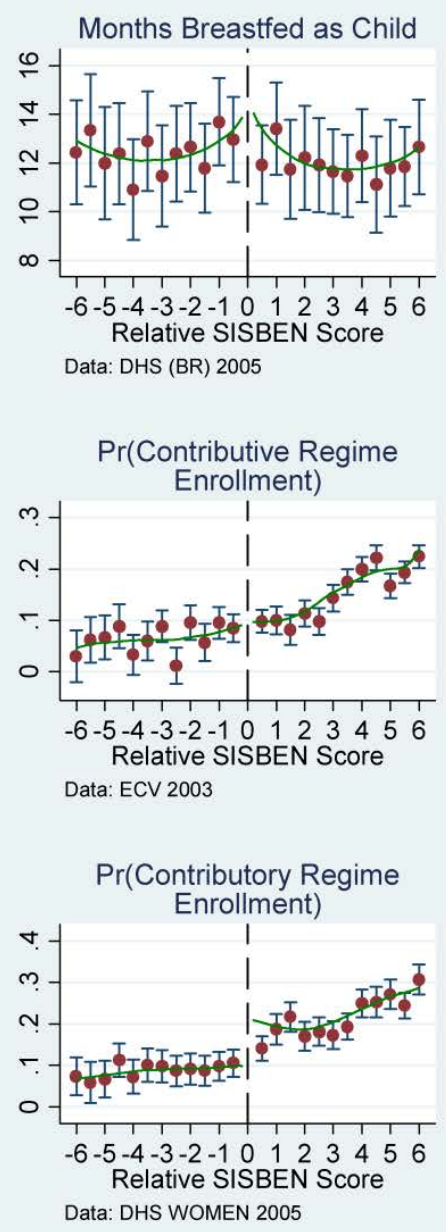
APPENDIX 5 TABLE 1:

ROBUSTNESS OF RISK PROTECTION AND PORTFOLIO CHOICE RESULTS

\begin{tabular}{|c|c|c|c|c|c|c|}
\hline Model: & $\begin{array}{c}\text { Individual } \\
\text { Inpatient } \\
\text { Medical } \\
\text { Spending }\end{array}$ & $\begin{array}{c}\text { Individual } \\
\text { Outpatient } \\
\text { Medical } \\
\text { Spending }\end{array}$ & $\begin{array}{c}\text { Variability of } \\
\text { Individual } \\
\text { Inpatient } \\
\text { Medical } \\
\text { Spending }\end{array}$ & $\begin{array}{c}\text { Variability of } \\
\text { Individual } \\
\text { Outpatient } \\
\text { Medical } \\
\text { Spending }\end{array}$ & & \\
\hline Bandwidth 2 & $\begin{array}{l}-58,870^{*} \\
{[33,263]}\end{array}$ & $\begin{array}{l}3,562 \\
{[2,702]}\end{array}$ & $\begin{array}{c}-67,499.38^{* * *} \\
{[32,906]}\end{array}$ & $\begin{array}{l}167.57 \\
{[2,417]}\end{array}$ & & \\
\hline Bandwidth 3 & $\begin{array}{r}-46,961 * \\
{[26,813]}\end{array}$ & $\begin{array}{c}703.76 \\
{[3,950.72]}\end{array}$ & $\begin{array}{c}-55,322.91 \text { *** } \\
{[26,608]}\end{array}$ & $\begin{array}{c}-3,073.60 \\
{[3,923]}\end{array}$ & & \\
\hline Bandwidth 4 & $\begin{array}{c}-62,449 * * \\
{[28,967]}\end{array}$ & $\begin{array}{l}2,544 \\
{[3,248]}\end{array}$ & $\begin{array}{c}-71,069.15^{* * *} \\
{[28,582]}\end{array}$ & $\begin{array}{c}-1,334.10 \\
{[3,226]}\end{array}$ & & \\
\hline Bandwidth 2 with Higher Order SISBEN Polynomial & $\begin{array}{l}-150,905 \\
{[107,544]}\end{array}$ & $\begin{array}{l}10,029 \\
{[7,035]}\end{array}$ & $\begin{array}{c}-159,204.24 \\
{[105,502]}\end{array}$ & $\begin{array}{c}6,722.59 \\
{[7,159]}\end{array}$ & & \\
\hline Bandwidth 3 with Higher Order SISBEN Polynomial & $\begin{array}{l}-83,857^{*} \\
{[44,116]}\end{array}$ & $\begin{array}{l}-93.44 \\
{[6,397]}\end{array}$ & $\begin{array}{c}-91,866.62 * * * \\
{[43,437]}\end{array}$ & $\begin{array}{c}-3,628.60 \\
{[6,269]}\end{array}$ & & \\
\hline Bandwidth 4 with Higher Order SISBEN Polynomial & $\begin{array}{l}-41,990 \\
{[31,578]}\end{array}$ & $\begin{array}{l}-1,483 \\
{[5,657]}\end{array}$ & $\begin{array}{c}-50,532.50 \\
{[31,467]}\end{array}$ & $\begin{array}{c}-5,146.52 \\
{[5,610]}\end{array}$ & & \\
\hline Bandwidth 2 with SISBEN×Eligible Interactions & $\begin{array}{l}-53,932 * \\
{[30,187]}\end{array}$ & $\begin{array}{l}4,128 \\
{[2,752]}\end{array}$ & $\begin{array}{c}-62,293.76^{* * *} \\
{[29,554]}\end{array}$ & $\begin{array}{l}824.61 \\
{[2,5534]}\end{array}$ & & \\
\hline Bandwidth 3 with SISBEN $\times$ Eligible Interactions & $\begin{array}{l}-43,836^{*} \\
{[24,405]}\end{array}$ & $\begin{array}{c}1,634 \\
{[3,608]}\end{array}$ & $\begin{array}{c}-52,273.19^{* * *} \\
{[24,152]}\end{array}$ & $\begin{array}{c}-2,133.27 \\
{[3,549]}\end{array}$ & & \\
\hline Bandwidth 4 with SISBEN $\times$ Eligible Interactions & $\begin{array}{c}-64,384 * * \\
{[31,236]}\end{array}$ & $\begin{array}{l}4,071 \\
{[2,666]}\end{array}$ & $\begin{array}{c}-73,063.09^{* *} \\
{[30,615]}\end{array}$ & $\begin{array}{l}166.82 \\
{[2,601]}\end{array}$ & & \\
\hline Bandwidth 2 without County Fixed Effects & $\begin{array}{l}-61,031 \\
{[39,242]}\end{array}$ & $\begin{array}{l}-1,996 \\
{[6,662]}\end{array}$ & $\begin{array}{c}-70,053.43^{*} \\
{[38,960]}\end{array}$ & $\begin{array}{c}-5,454.59 \\
{[6,619]}\end{array}$ & & \\
\hline Bandwidth 3 without County Fixed Effects & $\begin{array}{l}-44,811 \\
{[28,071]}\end{array}$ & $\begin{array}{l}-56.44 \\
{[4,774]}\end{array}$ & $\begin{array}{c}-53,497.76^{*} \\
{[27,960]}\end{array}$ & $\begin{array}{c}-3,782.96 \\
{[4,734]}\end{array}$ & & \\
\hline Bandwidth 4 without County Fixed Effects & $\begin{array}{c}-61,590^{* * *} \\
{[30,746]}\end{array}$ & $\begin{array}{c}1,343 \\
{[4,778]}\end{array}$ & $\begin{array}{c}-70,361.82^{* * *} \\
{[30,455]}\end{array}$ & $\begin{array}{c}-2,539.67 \\
{[4,753]}\end{array}$ & & \\
\hline Bandwidth 2 Local Linear Regression & $\begin{array}{l}-88,119 \\
{[65,068]}\end{array}$ & $\begin{array}{r}-120.65 \\
{[6,598]}\end{array}$ & $\begin{array}{c}-96,820.11 \\
{[64,134]}\end{array}$ & $\begin{array}{c}-3,434.45 \\
{[6,482]}\end{array}$ & & \\
\hline Bandwidth 3 Local Linear Regression & $\begin{array}{l}-59,699 \\
{[37,781]}\end{array}$ & $\begin{array}{l}155.77 \\
{[4,914]}\end{array}$ & $\begin{array}{c}-68,314.38^{*} \\
{[37,423]}\end{array}$ & $\begin{array}{c}-3,393.91 \\
{[4,810]}\end{array}$ & & \\
\hline Bandwidth 4 Local Linear Regression & $\begin{array}{l}-52,402 \\
{[32,325]}\end{array}$ & $\begin{array}{l}855.97 \\
{[4,294]}\end{array}$ & $\begin{array}{c}-61,162.26^{*} \\
{[32,082]}\end{array}$ & $\begin{array}{c}-2,798.77 \\
{[4,198]}\end{array}$ & & \\
\hline Data Source & ECV & ECV & ECV & ECV & & \\
\hline \multicolumn{7}{|l|}{ Panel B: Portfolio Choice } \\
\hline Model: & $\begin{array}{l}\text { Individual } \\
\text { Education } \\
\text { Spending } \\
\end{array}$ & $\begin{array}{l}\text { Household } \\
\text { Education } \\
\text { Spending } \\
\end{array}$ & $\begin{array}{l}\text { Total Spending } \\
\text { on Food }\end{array}$ & $\begin{array}{l}\text { Total Monthly } \\
\text { Expenditure }\end{array}$ & Has Car & Has Radio \\
\hline Bandwidth 2 & $\begin{array}{l}-341.68 \\
{[3,781]}\end{array}$ & $\begin{array}{l}30,366 \\
{[25,055]}\end{array}$ & $\begin{array}{c}32,136 \\
{[103,540]}\end{array}$ & $\begin{array}{c}-33,826 \\
{[278,060]}\end{array}$ & $\begin{array}{l}-0.01 \\
{[0.05]}\end{array}$ & $\begin{array}{c}0.15 \\
{[0.14]}\end{array}$ \\
\hline Bandwidth 3 & $\begin{array}{c}2,599 \\
{[5,408]}\end{array}$ & $\begin{array}{c}28,059 \\
{[28,1908]}\end{array}$ & $\begin{array}{l}-1,495 \\
{[92,076]}\end{array}$ & $\begin{array}{l}-320,415 \\
{[351,586]}\end{array}$ & $\begin{array}{c}0.02 \\
{[0.04]}\end{array}$ & $\begin{array}{c}0.09 \\
{[0.11]}\end{array}$ \\
\hline Bandwidth 4 & $\begin{array}{c}2,613 \\
{[5,186]}\end{array}$ & $\begin{array}{l}25,670 \\
{[30,120]}\end{array}$ & $\begin{array}{c}18,654 \\
{[85,054]}\end{array}$ & $\begin{array}{l}-348,373 \\
{[372,119]}\end{array}$ & $\begin{array}{c}0.03 \\
{[0.04]}\end{array}$ & $\begin{array}{c}0.03 \\
{[0.12]}\end{array}$ \\
\hline Bandwidth 2 with Higher Order SISBEN Polynomial & $\begin{array}{l}-7,023 \\
{[7,529]}\end{array}$ & $\begin{array}{c}7,150 \\
{[24,022]}\end{array}$ & $\begin{array}{c}3,136 \\
{[209,963]}\end{array}$ & $\begin{array}{c}-776,577 * * \\
{[445,614]}\end{array}$ & $\begin{array}{l}-0.01 \\
{[0.05]}\end{array}$ & $\begin{array}{c}0.15 \\
{[0.14]}\end{array}$ \\
\hline Bandwidth 3 with Higher Order SISBEN Polynomial & $\begin{array}{l}-2,350 \\
{[3,918]}\end{array}$ & $\begin{array}{l}27,095 \\
{[28,643]}\end{array}$ & $\begin{array}{c}27,129 \\
{[125,891]}\end{array}$ & $\begin{array}{l}-362,101 \\
{[372,691]}\end{array}$ & $\begin{array}{l}-0.02 \\
{[0.04]}\end{array}$ & $\begin{array}{c}0.12 \\
{[0.11]}\end{array}$ \\
\hline Bandwidth 4 with Higher Order SISBEN Polynomial & $\begin{array}{l}1,842 \\
{[4,851]}\end{array}$ & $\begin{array}{l}28,281 \\
{[28,097]}\end{array}$ & $\begin{array}{c}14,132 \\
{[93,018]}\end{array}$ & $\begin{array}{l}-319,591 \\
{[340,240}\end{array}$ & $\begin{array}{c}0.02 \\
{[0.04]}\end{array}$ & $\begin{array}{c}0.11 \\
{[0.10]}\end{array}$ \\
\hline Bandwidth 2 with SISBEN×Eligible Interactions & $\begin{array}{l}-1,384 \\
{[3,754]}\end{array}$ & $\begin{array}{l}30,593 \\
{[25,749]}\end{array}$ & $\begin{array}{c}32,790 \\
{[101,536]}\end{array}$ & $\begin{array}{c}-63,185 \\
{[287,655]}\end{array}$ & $\begin{array}{c}0.01 \\
{[0.03]}\end{array}$ & $\begin{array}{c}0.16 \\
{[0.11]}\end{array}$ \\
\hline Bandwidth 3 with SISBEN $\times$ Eligible Interactions & $\begin{array}{l}1,884 \\
{[5,357]}\end{array}$ & $\begin{array}{l}25,782 \\
{[28,574]}\end{array}$ & $\begin{array}{l}-837.43 \\
{[99,064]}\end{array}$ & $\begin{array}{l}-326,491 \\
{[363,209]}\end{array}$ & $\begin{array}{l}0.02 \\
{[0.04]}\end{array}$ & $\begin{array}{c}0.08 \\
{[0.10]}\end{array}$ \\
\hline Bandwidth 4 with SISBEN $\times$ Eligible Interactions & $\begin{array}{l}2,243 \\
{[5,129]}\end{array}$ & $\begin{array}{l}24,374 \\
{[30,313]}\end{array}$ & $\begin{array}{l}27,751 \\
{[95,376]}\end{array}$ & $\begin{array}{l}-230,269 \\
{[343,713]}\end{array}$ & $\begin{array}{l}0.03 \\
{[0.04]}\end{array}$ & $\begin{array}{c}0.03 \\
{[0.12]}\end{array}$ \\
\hline Bandwidth 2 without County Fixed Effects & $\begin{array}{l}3,595 \\
{[3,556]}\end{array}$ & $\begin{array}{l}40,950^{*} \\
{[24,025]}\end{array}$ & $\begin{array}{c}-76.00 \\
{[109,894]}\end{array}$ & $\begin{array}{c}7,924 \\
{[378,659]}\end{array}$ & $\begin{array}{c}0.01 \\
{[0.04]}\end{array}$ & $\begin{array}{c}0.18 \\
{[0.12]}\end{array}$ \\
\hline Bandwidth 3 without County Fixed Effects & $\begin{array}{l}4,882 \\
{[5,094]}\end{array}$ & $\begin{array}{l}31,351 \\
{[26,704]}\end{array}$ & $\begin{array}{c}-5,734 \\
{[100,300]}\end{array}$ & $\begin{array}{l}-315,118 \\
{[379,380]}\end{array}$ & $\begin{array}{c}0.03 \\
{[0.04]}\end{array}$ & $\begin{array}{c}0.09 \\
{[0.12]}\end{array}$ \\
\hline Bandwidth 4 without County Fixed Effects & $\begin{array}{l}4,495 \\
{[5,335]}\end{array}$ & $\begin{array}{l}29,234 \\
{[29,591]}\end{array}$ & $\begin{array}{c}8,948 \\
{[97,637]}\end{array}$ & $\begin{array}{l}-466,629 \\
{[386,631]}\end{array}$ & $\begin{array}{c}0.03 \\
{[0.04]}\end{array}$ & $\begin{array}{c}0.06 \\
{[0.14]}\end{array}$ \\
\hline Bandwidth 2 Local Linear Regression & $\begin{array}{l}8,457 \\
{[7,815]}\end{array}$ & $\begin{array}{l}60,037 \\
{[45,284]}\end{array}$ & $\begin{array}{c}-29,196 \\
{[157,519]}\end{array}$ & $\begin{array}{c}-365,953 \\
{[2,984,775]}\end{array}$ & $\begin{array}{c}0.01 \\
{[0.042]}\end{array}$ & $\begin{array}{c}0.14 \\
{[0.121]}\end{array}$ \\
\hline Bandwidth 3 Local Linear Regression & $\begin{array}{l}7,512 \\
{[7,113]}\end{array}$ & $\begin{array}{l}50,717 \\
{[39,165]}\end{array}$ & $\begin{array}{c}-10,243 \\
{[130,782]}\end{array}$ & $\begin{array}{c}-202,306 \\
{[4,347,890]}\end{array}$ & $\begin{array}{c}0.02 \\
{[0.035]}\end{array}$ & $\begin{array}{c}0.12 \\
{[0.109]}\end{array}$ \\
\hline Bandwidth 4 Local Linear Regression & $\begin{array}{c}7,619 \\
{[7,174]}\end{array}$ & $\begin{array}{l}46,440 \\
{[37,423]}\end{array}$ & $\begin{array}{c}3,082 \\
{[128,102]}\end{array}$ & $\begin{array}{l}-238,253 \\
{[459,354]}\end{array}$ & $\begin{array}{c}0.02 \\
{[0.034]}\end{array}$ & $\begin{array}{c}0.09 \\
{[0.118]}\end{array}$ \\
\hline Data Source & ECV & $\mathrm{ECV}$ & $\mathrm{ECV}$ & ECV & DHS & DHS \\
\hline
\end{tabular}

Individual-level "urban" data used from the $2003 \mathrm{ECV}$ and 2005 DHS. Dependent variables are shown at the top of each column; all estimates are 2SLS estimates for enrollment in the Subsidized Regime (SR), instrumenting for SR enrollment using simulated eligibility. The first three rows report estimates using samples of individuals within two, three, and
four SISBEN index points of county-specific eligibility thresholds (respectively). The fourth through sixth rows control for squared, cubic, and fourth power terms of SISBEN scores using samples of individuals within two, three, and four SISBEN index points of county-specific eligibility thresholds (respectively). The seventh through ninth rows include interactions between SISBEN scores and an indicator variable for eligibility according to our calculations. The tenth through twelfth rows do not condition on county fixed effects and use samples of individuals within two, three, and four SISBEN index points of county-specific eligibility thresholds (respectively). The thirteenth through fiffteenth rows report nonparametric local linear regression estimates obtained through the following process. First, local linear regression functions (with triangle kernels) are used to estimate conditional means (conditioning only on SISBEN_diff) of outcome variables on either side of the eligiblitity threshold. Second, this estimation process is repeated for enrollment in the SR.

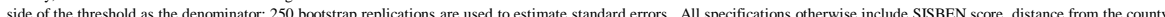
side of the threshold as the denominator; 250 bootstrap replications are used to estimate standard errors. All specifications otherwise include SISBEN score, distance from the county-
specific threshold, estrato dummy variables, and county fixed effects. Standard errors (clustered by household) are shown in brackets below each estimate. * ${ }^{p}<0.10$, ** $p<0.05$, 
APPENDIX 5 TABLE 2:

\begin{tabular}{|c|c|c|c|c|c|c|}
\hline & \multicolumn{2}{|c|}{ Use of Preventive Care } & \multicolumn{4}{|c|}{ Health Status (Children) } \\
\hline Model: & $\begin{array}{l}\text { Preventive } \\
\text { Physician } \\
\text { Visit }\end{array}$ & $\begin{array}{c}\text { Number of } \\
\text { Growth Dev. } \\
\text { Checks Last } \\
\text { Year }\end{array}$ & $\begin{array}{l}\text { Child Days } \\
\text { Lost to Illness }\end{array}$ & $\begin{array}{c}\text { Cough, Fever, } \\
\text { Diarrhea }\end{array}$ & $\begin{array}{l}\text { Any Health } \\
\text { Problem }\end{array}$ & $\begin{array}{c}\text { Birthweight } \\
\text { (KG) }\end{array}$ \\
\hline Bandwidth 2 & $\begin{array}{c}0.29 * * * \\
{[0.11]}\end{array}$ & $\begin{array}{c}1.50 * * \\
{[0.69]}\end{array}$ & $\begin{array}{c}-1.40 * * \\
{[0.65]}\end{array}$ & $\begin{array}{l}-0.18 \\
{[0.17]}\end{array}$ & $\begin{array}{l}-0.06 \\
{[0.18]}\end{array}$ & $\begin{array}{c}0.26 \\
{[0.29]}\end{array}$ \\
\hline Bandwidth 3 & $\begin{array}{c}0.20^{* * *} \\
{[0.10]}\end{array}$ & $\begin{array}{l}1.43^{* * *} \\
{[0.68]}\end{array}$ & $\begin{array}{l}-0.96 \\
{[0.74]}\end{array}$ & $\begin{array}{l}-0.12 \\
{[0.18]}\end{array}$ & $\begin{array}{l}-0.14 \\
{[0.17]}\end{array}$ & $\begin{array}{l}-0.08 \\
{[0.28]}\end{array}$ \\
\hline Bandwidth 4 & $\begin{array}{l}0.24 * * \\
{[0.09]}\end{array}$ & $\begin{array}{l}1.43^{* *} \\
{[0.66]}\end{array}$ & $\begin{array}{l}-1.52 * \\
{[0.91]}\end{array}$ & $\begin{array}{l}-0.23 \\
{[0.18]}\end{array}$ & $\begin{array}{l}-0.25 \\
{[0.18]}\end{array}$ & $\begin{array}{c}0.05 \\
{[0.30]}\end{array}$ \\
\hline Bandwidth 2 with Higher Order SISBEN Polynomial & $\begin{array}{c}0.40 \\
{[0.29]}\end{array}$ & $\begin{array}{c}1.66^{* * *} \\
{[0.83]}\end{array}$ & $\begin{array}{l}-1.00 \\
{[0.66]}\end{array}$ & $\begin{array}{c}-0.46^{*} \\
{[0.24]}\end{array}$ & $\begin{array}{l}-0.20 \\
{[0.23]}\end{array}$ & $\begin{array}{l}-0.13 \\
{[0.36]}\end{array}$ \\
\hline Bandwidth 3 with Higher Order SISBEN Polynomial & $\begin{array}{c}0.48 * * * \\
{[0.15]}\end{array}$ & $\begin{array}{l}1.33 * \\
{[0.78]}\end{array}$ & $\begin{array}{c}-1.13^{*} \\
{[0.62]}\end{array}$ & $\begin{array}{l}-0.21 \\
{[0.16]}\end{array}$ & $\begin{array}{l}-0.07 \\
{[0.17]}\end{array}$ & $\begin{array}{c}0.31 \\
{[0.28]}\end{array}$ \\
\hline Bandwidth 4 with Higher Order SISBEN Polynomial & $\begin{array}{l}0.26^{* *} \\
{[0.11]}\end{array}$ & $\begin{array}{l}1.76^{* * *} \\
{[0.75]}\end{array}$ & $\begin{array}{l}-1.06 \\
{[0.68]}\end{array}$ & $\begin{array}{l}-0.16 \\
{[0.19]}\end{array}$ & $\begin{array}{l}-0.14 \\
{[0.19]}\end{array}$ & $\begin{array}{c}0.02 \\
{[0.29]}\end{array}$ \\
\hline Bandwidth 2 with SISBEN $\times$ Eligible Interactions & $\begin{array}{l}0.27 * * \\
{[0.10]}\end{array}$ & $\begin{array}{c}1.51^{* *} \\
{[0.68]}\end{array}$ & $\begin{array}{c}-1.40 * * \\
{[0.63]}\end{array}$ & $\begin{array}{l}-0.19 \\
{[0.17]}\end{array}$ & $\begin{array}{l}-0.06 \\
{[0.18]}\end{array}$ & $\begin{array}{c}0.27 \\
{[0.29]}\end{array}$ \\
\hline Bandwidth 3 with SISBEN $\times$ Eligible Interactions & $\begin{array}{c}0.21^{* *} \\
{[0.09]}\end{array}$ & $\begin{array}{c}1.39 * * \\
{[0.68]}\end{array}$ & $\begin{array}{l}-0.90 \\
{[0.71]}\end{array}$ & $\begin{array}{l}-0.11 \\
{[0.18]}\end{array}$ & $\begin{array}{l}-0.14 \\
{[0.17]}\end{array}$ & $\begin{array}{l}-0.09 \\
{[0.28]}\end{array}$ \\
\hline Bandwidth 4 with SISBEN $\times$ Eligible Interactions & $\begin{array}{c}0.23^{* *} \\
{[0.10]}\end{array}$ & $\begin{array}{c}1.43^{* *} \\
{[0.66]}\end{array}$ & $\begin{array}{l}-1.52^{*} \\
{[0.90]}\end{array}$ & $\begin{array}{l}-0.23 \\
{[0.18]}\end{array}$ & $\begin{array}{l}-0.25 \\
{[0.18]}\end{array}$ & $\begin{array}{c}0.05 \\
{[0.30]}\end{array}$ \\
\hline Bandwidth 2 without County Fixed Effects & $\begin{array}{c}0.46^{* * *} * \\
{[0.12]}\end{array}$ & $\begin{array}{c}1.56^{* * *} \\
{[0.60]}\end{array}$ & $\begin{array}{c}-1.57 * * * \\
{[0.57]}\end{array}$ & $\begin{array}{c}-0.25^{*} \\
{[0.15]}\end{array}$ & $\begin{array}{l}-0.19 \\
{[0.15]}\end{array}$ & $\begin{array}{c}0.23 \\
{[0.25]}\end{array}$ \\
\hline Bandwidth 3 without County Fixed Effects & $\begin{array}{c}0.32 * * * \\
{[0.10]}\end{array}$ & $\begin{array}{c}1.55^{* *} \\
{[0.61]}\end{array}$ & $\begin{array}{c}-1.48^{* *} \\
{[0.63]}\end{array}$ & $\begin{array}{l}-0.19 \\
{[0.16]}\end{array}$ & $\begin{array}{l}-0.20 \\
{[0.16]}\end{array}$ & $\begin{array}{l}-0.14 \\
{[0.26]}\end{array}$ \\
\hline Bandwidth 4 without County Fixed Effects & $\begin{array}{c}0.31 * * * \\
{[0.09]}\end{array}$ & $\begin{array}{c}1.44 * * \\
{[0.60]}\end{array}$ & $\begin{array}{c}-1.72 * * \\
{[0.73]}\end{array}$ & $\begin{array}{c}-0.29 * \\
{[0.17]}\end{array}$ & $\begin{array}{c}-0.33 * \\
{[0.17]}\end{array}$ & $\begin{array}{c}0.01 \\
{[0.25]}\end{array}$ \\
\hline Bandwidth 2 Local Linear Regression & $\begin{array}{c}0.72 * * \\
{[0.36]}\end{array}$ & $\begin{array}{l}1.68 * * \\
{[0.708]}\end{array}$ & $\begin{array}{c}-1.26 * * \\
{[0.533]}\end{array}$ & $\begin{array}{c}-0.39 * * \\
{[0.170]}\end{array}$ & $\begin{array}{l}-0.30 * \\
{[0.174]}\end{array}$ & $\begin{array}{c}0.03 \\
{[0.310]}\end{array}$ \\
\hline Bandwidth 3 Local Linear Regression & $\begin{array}{c}0.55^{* * *} \\
{[0.22]}\end{array}$ & $\begin{array}{l}1.50 * * \\
{[0.635]}\end{array}$ & $\begin{array}{c}-1.44 * * * \\
{[0.554]}\end{array}$ & $\begin{array}{c}-0.28 * \\
{[0.150]}\end{array}$ & $\begin{array}{c}-0.23 \\
{[0.154]}\end{array}$ & $\begin{array}{c}0.03 \\
{[0.275]}\end{array}$ \\
\hline Bandwidth 4 Local Linear Regression & $\begin{array}{c}0.45^{* * *} \\
{[0.18]}\end{array}$ & $\begin{array}{c}1.51 \text { *** } \\
{[0.583]}\end{array}$ & $\begin{array}{c}-1.54 * * * \\
{[0.578]}\end{array}$ & $\begin{array}{l}-0.27 * \\
{[0.150]}\end{array}$ & $\begin{array}{l}-0.27 * \\
{[0.155]}\end{array}$ & $\begin{array}{c}-0.02 \\
{[0.271]}\end{array}$ \\
\hline Data Source & $\mathrm{ECV}$ & DHS & DHS & DHS & DHS & DHS \\
\hline $\begin{array}{l}\text { Individual-level "urban" data used from the } 2003 \text { ECV anc } \\
\text { enrollment in the Subsidized Regime (SR), instrumenting fo } \\
\text { within two, three, and four SISBEN index points of count } \\
\text { fourth power terms of SISBEN scores using samples o } \\
\text { (respectively). The seventh through ninth rows include inte } \\
\text { tenth through twelfth rows do not condition on county fixe } \\
\text { eligibility thresholds (respectively). The thirteenth through } \\
\text { First, local linear regression functions (with triangle kernel } \\
\text { side of the eligibility threshold. Second, this estimation } \\
\text { outcome variable means on either side of the threshold as n } \\
\text { bootstrap replications are used to estimate standard error } \\
\text { dummy variables, and county fixed effects. Standard errors }\end{array}$ & $\begin{array}{l}\text { HS. Depender } \\
\text { rollment using } \\
\text { eligibility thr } \\
\text { luals within } t \\
\text { between SISB } \\
\text { and use samp } \\
\text { rows report n } \\
\text { ed to estimate } \\
\mathrm{s} \text { repeated for } \\
\text { rs and the diffe } \\
\text { pecifications o } \\
\text { ed by househol }\end{array}$ & $\begin{array}{l}\text { t variables are sl } \\
\text { imulated eligibil } \\
\text { sholds (respecti } \\
\text { o, three, and f } \\
\text { EN scores and al } \\
\text { les of individuals } \\
\text { n-parametric loc } \\
\text { onditional mean } \\
\text { enrollment in th } \\
\text { rence in SR enro } \\
\text { herwise include } \\
\text { d) are shown in b }\end{array}$ & $\begin{array}{l}\text { n at the top of ea } \\
\text { The first three ro } \\
\text { y). The fourth th } \\
\text { SISBEN index } \\
\text { dicator variable } \mathrm{f} \\
\text { ithin two, three, a } \\
\text { inear regression e } \\
\text { conditioning only } \\
\text { SR. Finally, Wal } \\
\text { ent means on eith } \\
\text { BEN score, dista } \\
\text { kets below each e }\end{array}$ & $\begin{array}{l}\text { ach column; all e } \\
\text { ows report estima } \\
\text { rrough sixth rows } \\
\text { points of count } \\
\text { for eligibility acc } \\
\text { and four SISBEN } \\
\text { estimates obtaine } \\
\text { on SISBEN_diff } \\
\text { ld statistics are c } \\
\text { her side of the thr } \\
\text { ance from the co } \\
\text { estimate. }{ }^{*} \mathrm{p}<0.1\end{array}$ & $\begin{array}{l}\text { stimates are } 2 \mathrm{Sl} \\
\text { tes using sampl } \\
\text { control for squ } \\
y \text {-specific eligit } \\
\text { ording to our ca } \\
\text { index points of } \\
1 \text { through the fo } \\
\text { of outcome va } \\
\text { onstructed usin } \\
\text { eshold as the d } \\
\text { unty-specific th } \\
, * * p<0.05, * * *\end{array}$ & $\begin{array}{l}\text { S estimates for } \\
\mathrm{s} \text { of individuals } \\
\text { red, cubic, and } \\
\text { ility thresholds } \\
\text { lculations. The } \\
\text { county-specific } \\
\text { lowing process. } \\
\text { iables on either } \\
\text { differences in } \\
\text { nominator; } 250 \\
\text { reshold, estrato } \\
\text { p }<0.01 \text {. }\end{array}$ \\
\hline
\end{tabular}


APPENDIX 5 TABLE 3:

ROBUSTNESS OF USE OF CURATIVE MEDICAL CARE RESULTS

\begin{tabular}{|c|c|c|c|c|}
\hline Model: & $\begin{array}{l}\text { Curative Use } \\
\text { (Not } \\
\text { Conditonal on } \\
\text { Health Status) }\end{array}$ & $\begin{array}{c}\text { Curative Use } \\
\text { among } \\
\text { Children (Not } \\
\text { Conditional on } \\
\text { Health Status) }\end{array}$ & $\begin{array}{l}\text { Medical Visit } \\
\text { for Chronic } \\
\text { Disease }\end{array}$ & Hospital Stay \\
\hline Bandwidth 2 & $\begin{array}{c}0.13 * * \\
{[0.05]}\end{array}$ & $\begin{array}{l}-0.00 \\
{[0.16]}\end{array}$ & $\begin{array}{l}0.51 * \\
{[0.28]}\end{array}$ & $\begin{array}{l}-0.04 \\
{[0.11]}\end{array}$ \\
\hline Bandwidth 3 & $\begin{array}{c}0.15^{\text {**** }} \\
{[0.03]}\end{array}$ & $\begin{array}{l}-0.01 \\
{[0.16]}\end{array}$ & $\begin{array}{c}0.26 \\
{[0.27]}\end{array}$ & $\begin{array}{l}-0.05 \\
{[0.07]}\end{array}$ \\
\hline Bandwidth 4 & $\begin{array}{c}0.16^{* * * *} \\
{[0.04]}\end{array}$ & $\begin{array}{l}-0.11 \\
{[0.16]}\end{array}$ & $\begin{array}{c}0.60^{* *} \\
{[0.27]}\end{array}$ & $\begin{array}{l}-0.03 \\
{[0.07]}\end{array}$ \\
\hline Bandwidth 2 with Higher Order SISBEN Polynomial & $\begin{array}{c}0.23 * * \\
{[0.10]}\end{array}$ & $\begin{array}{l}-0.10 \\
{[0.23]}\end{array}$ & $\begin{array}{c}1.79 \\
{[1.59]}\end{array}$ & $\begin{array}{l}-0.08 \\
{[0.28]}\end{array}$ \\
\hline Bandwidth 3 with Higher Order SISBEN Polynomial & $\begin{array}{c}0.18^{* * *} \\
{[0.06]}\end{array}$ & $\begin{array}{c}0.03 \\
{[0.17]}\end{array}$ & $\begin{array}{c}0.83 \\
{[0.53]}\end{array}$ & $\begin{array}{l}-0.07 \\
{[0.16]}\end{array}$ \\
\hline Bandwidth 4 with Higher Order SISBEN Polynomial & $\begin{array}{c}0.14 * * * \\
{[0.04]}\end{array}$ & $\begin{array}{c}0.05 \\
{[0.18]}\end{array}$ & $\begin{array}{c}0.21 \\
{[0.18]}\end{array}$ & $\begin{array}{l}-0.03 \\
{[0.08]}\end{array}$ \\
\hline Bandwidth 2 with SISBEN $\times$ Eligible Interactions & $\begin{array}{c}0.12 * * \\
{[0.05]}\end{array}$ & $\begin{array}{l}-0.00 \\
{[0.16]}\end{array}$ & $\begin{array}{c}0.56^{* * *} \\
{[0.28]}\end{array}$ & $\begin{array}{l}-0.03 \\
{[0.12]}\end{array}$ \\
\hline Bandwidth 3 with SISBEN $\times$ Eligible Interactions & $\begin{array}{c}0.15^{* * *} * \\
{[0.03]}\end{array}$ & $\begin{array}{l}-0.00 \\
{[0.16]}\end{array}$ & $\begin{array}{c}0.28 \\
{[0.28]}\end{array}$ & $\begin{array}{l}-0.04 \\
{[0.08]}\end{array}$ \\
\hline Bandwidth 4 with SISBEN $\times$ Eligible Interactions & $\begin{array}{c}0.16^{* * * *} \\
{[0.04]}\end{array}$ & $\begin{array}{l}-0.11 \\
{[0.16]}\end{array}$ & $\begin{array}{c}0.60 * * \\
{[0.30]}\end{array}$ & $\begin{array}{l}-0.03 \\
{[0.08]}\end{array}$ \\
\hline Bandwidth 2 without County Fixed Effects & $\begin{array}{c}0.14 * * \\
{[0.06]}\end{array}$ & $\begin{array}{l}-0.13 \\
{[0.16]}\end{array}$ & $\begin{array}{c}0.41^{* *} \\
{[0.19]}\end{array}$ & $\begin{array}{l}-0.00 \\
{[0.11]}\end{array}$ \\
\hline Bandwidth 3 without County Fixed Effects & $\begin{array}{c}0.14^{* * * *} \\
{[0.03]}\end{array}$ & $\begin{array}{l}-0.21 \\
{[0.20]}\end{array}$ & $\begin{array}{c}0.22 \\
{[0.19]}\end{array}$ & $\begin{array}{l}-0.01 \\
{[0.07]}\end{array}$ \\
\hline Bandwidth 4 without County Fixed Effects & $\begin{array}{c}0.16^{* * * *} \\
{[0.04]}\end{array}$ & $\begin{array}{l}-0.19 \\
{[0.15]}\end{array}$ & $\begin{array}{c}0.55^{* * * *} \\
{[0.19]}\end{array}$ & $\begin{array}{c}0.00 \\
{[0.07]}\end{array}$ \\
\hline Bandwidth 2 Local Linear Regression & $\begin{array}{c}0.13 * * \\
{[0.06]}\end{array}$ & $\begin{array}{c}-0.19 \\
{[0.184]}\end{array}$ & $\begin{array}{c}0.99 \\
{[0.61]}\end{array}$ & $\begin{array}{c}0.01 \\
{[0.17]}\end{array}$ \\
\hline Bandwidth 3 Local Linear Regression & $\begin{array}{c}0.13^{* * *} \\
{[0.04]}\end{array}$ & $\begin{array}{c}-0.16 \\
{[0.154]}\end{array}$ & $\begin{array}{c}0.55 \\
{[0.79]}\end{array}$ & $\begin{array}{c}0.00 \\
{[0.11]}\end{array}$ \\
\hline Bandwidth 4 Local Linear Regression & $\begin{array}{c}0.14^{* * * *} \\
{[0.04]}\end{array}$ & $\begin{array}{c}-0.17 \\
{[0.142]}\end{array}$ & $\begin{array}{c}0.48 \\
{[0.42]}\end{array}$ & $\begin{array}{c}0.01 \\
{[0.09]}\end{array}$ \\
\hline Data Source & $\mathrm{ECV}$ & DHS & $\mathrm{ECV}$ & $\mathrm{ECV}$ \\
\hline \multicolumn{5}{|c|}{$\begin{array}{l}\text { Individual-level "urban" data used from the } 2003 \text { ECV and } 2005 \text { DHS. Dependent variables are shown at the top of each column; all estimates are } \\
\text { 2SLS estimates for enrollment in the Subsidized Regime (SR), instrumenting for SR enrollment using simulated eligibility. The first three rows report } \\
\text { estimates using samples of individuals within two, three, and four SISBEN index points of county-specific eligibility thresholds (respectively). The } \\
\text { fourth through sixth rows control for squared, cubic, and fourth power terms of SISBEN scores using samples of individuals within two, three, and } \\
\text { four SISBEN index points of county-specific eligibility thresholds (respectively). The seventh through ninth rows include interactions between } \\
\text { SISBEN scores and an indicator variable for eligibility according to our calculations. The tenth through twelfth rows do not condition on county fixed } \\
\text { effects and use samples of individuals within two, three, and four SISBEN index points of county-specific eligibility thresholds (respectively). The } \\
\text { thirteenth through fifteenth rows report non-parametric local linear regression estimates obtained through the following process. First, local linear } \\
\text { regression functions (with triangle kernels) are used to estimate conditional means (conditioning only on SISBEN_diff) of outcome variables on either } \\
\text { side of the eligibility threshold. Second, this estimation process is repeated for enrollment in the SR. Finally, Wald statistics are constructed using } \\
\text { differences in outcome variable means on either side of the threshold as numerators and the difference in SR enrollment means on either side of the } \\
\text { threshold as the denominator; } 250 \text { bootstrap replications are used to estimate standard errors. All specifications otherwise include SISBEN score, } \\
\text { distance from the county-specific threshold, estrato dummy variables, and county fixed effects. Standard errors (clustered by household) are shown in } \\
\text { brackets below each estimate. } * \mathrm{p}<0.10, * * p<0.05, * * * p<0.01 \text {. }\end{array}$} \\
\hline
\end{tabular}


APPENDIX 5 TABLE 4:

ROBUSTNESS OF BEHAVIORAL DISORTION RESULTS (EX ANTE MORAL HAZARD)

\begin{tabular}{|c|c|c|c|}
\hline Model: & $\begin{array}{c}\text { Drank Alcohol } \\
\text { during } \\
\text { Pregnancy }\end{array}$ & $\begin{array}{c}\text { Months } \\
\text { Breastfed as } \\
\text { Child }\end{array}$ & $\begin{array}{c}\text { Folic Acid } \\
\text { During } \\
\text { Pregnancy }\end{array}$ \\
\hline Bandwidth 2 & $\begin{array}{l}-0.10 \\
{[0.11]}\end{array}$ & $\begin{array}{c}-0.23 \\
{[5.36]}\end{array}$ & $\begin{array}{c}0.10 \\
{[0.18]}\end{array}$ \\
\hline Bandwidth 3 & $\begin{array}{c}0.01 \\
{[0.10]}\end{array}$ & $\begin{array}{c}-0.71 \\
{[4.41]}\end{array}$ & $\begin{array}{c}0.16 \\
{[0.16]}\end{array}$ \\
\hline Bandwidth 4 & $\begin{array}{c}-0.01 \\
{[0.10]}\end{array}$ & $\begin{array}{c}0.84 \\
{[3.97]}\end{array}$ & $\begin{array}{c}0.05 \\
{[0.17]}\end{array}$ \\
\hline Bandwidth 2 with Higher Order SISBEN Polynomial & $\begin{array}{c}-0.11 \\
{[0.12]}\end{array}$ & $\begin{array}{c}0.14 \\
{[6.72]}\end{array}$ & $\begin{array}{c}0.05 \\
{[0.18]}\end{array}$ \\
\hline Bandwidth 3 with Higher Order SISBEN Polynomial & $\begin{array}{l}-0.03 \\
{[0.12]}\end{array}$ & $\begin{array}{c}-0.44 \\
{[5.11]}\end{array}$ & $\begin{array}{c}0.06 \\
{[0.18]}\end{array}$ \\
\hline Bandwidth 4 with Higher Order SISBEN Polynomial & $\begin{array}{c}-0.03 \\
{[0.10]}\end{array}$ & $\begin{array}{l}-1.80 \\
{[4.95]}\end{array}$ & $\begin{array}{c}0.16 \\
{[0.17]}\end{array}$ \\
\hline Bandwidth 2 with SISBEN $\times$ Eligible Interactions & $\begin{array}{c}-0.10 \\
{[0.11]}\end{array}$ & $\begin{array}{c}-0.24 \\
{[5.37]}\end{array}$ & $\begin{array}{c}0.10 \\
{[0.18]}\end{array}$ \\
\hline Bandwidth 3 with SISBEN $\times$ Eligible Interactions & $\begin{array}{c}0.01 \\
{[0.10]}\end{array}$ & $\begin{array}{c}-0.47 \\
{[4.43]}\end{array}$ & $\begin{array}{c}0.16 \\
{[0.16]}\end{array}$ \\
\hline Bandwidth 4 with SISBEN $\times$ Eligible Interactions & $\begin{array}{c}-0.00 \\
{[0.10]}\end{array}$ & $\begin{array}{c}0.90 \\
{[3.98]}\end{array}$ & $\begin{array}{c}0.05 \\
{[0.17]}\end{array}$ \\
\hline Bandwidth 2 without County Fixed Effects & $\begin{array}{c}-0.12 \\
{[0.11]}\end{array}$ & $\begin{array}{c}3.54 \\
{[4.39]}\end{array}$ & $\begin{array}{c}0.18 \\
{[0.18]}\end{array}$ \\
\hline Bandwidth 3 without County Fixed Effects & $\begin{array}{c}-0.02 \\
{[0.10]}\end{array}$ & $\begin{array}{c}3.14 \\
{[4.25]}\end{array}$ & $\begin{array}{c}0.16 \\
{[0.15]}\end{array}$ \\
\hline Bandwidth 4 without County Fixed Effects & $\begin{array}{c}-0.03 \\
{[0.10]}\end{array}$ & $\begin{array}{c}3.37 \\
{[3.76]}\end{array}$ & $\begin{array}{c}0.09 \\
{[0.16]}\end{array}$ \\
\hline Bandwidth 2 Local Linear Regression & $\begin{array}{c}-0.13 \\
{[0.116]}\end{array}$ & $\begin{array}{c}5.13 \\
{[4.766]}\end{array}$ & $\begin{array}{c}0.18 \\
{[0.199]}\end{array}$ \\
\hline Bandwidth 3 Local Linear Regression & $\begin{array}{c}-0.05 \\
{[0.102]}\end{array}$ & $\begin{array}{c}4.44 \\
{[4.254]}\end{array}$ & $\begin{array}{c}0.16 \\
{[0.171]}\end{array}$ \\
\hline Bandwidth 4 Local Linear Regression & $\begin{array}{c}-0.04 \\
{[0.099]}\end{array}$ & $\begin{array}{c}3.86 \\
{[3.786]}\end{array}$ & $\begin{array}{c}0.15 \\
{[0.159]}\end{array}$ \\
\hline Data Source & DHS & DHS & DHS \\
\hline
\end{tabular}

Individual-level "urban" data used from the 2003 ECV and 2005 DHS. Dependent variables are shown at the top of each column; all estimates are 2SLS estimates for enrollment in the Subsidized Regime (SR), instrumenting for SR enrollment using simulated eligibility. The first three rows report estimates using samples of individuals within two, three, and four SISBEN index points of county-specific eligibility thresholds (respectively). The fourth through sixth rows control for squared, cubic, and fourth power terms of SISBEN scores using samples of individuals within two, three, and four SISBEN index points of county-specific eligibility thresholds (respectively). The seventh through ninth rows include interactions between SISBEN scores and an indicator variable for eligibility according to our calculations. The tenth through twelfth rows do not condition on county fixed effects and use samples of individuals within two, three, and four SISBEN index points of county-specific eligibility thresholds (respectively). The thirteenth through fifteenth rows report non-parametric local linear regression estimates obtained through the following process. First, local linear regression functions (with triangle kernels) are used to estimate conditional means (conditioning only on SISBEN_diff) of outcome variables on either side of the eligibility threshold. Second, this estimation process is repeated for enrollment in the SR. Finally, Wald statistics are constructed using differences in outcome variable means on either side of the threshold as numerators and the difference in SR enrollment means on either side of the threshold as the denominator; 250 bootstrap replications are used to estimate standard errors. All specifications otherwise include SISBEN score, distance from the county-specific threshold, estrato dummy variables, and county fixed effects. Standard errors (clustered by household) are shown in brackets below each estimate. ${ }^{*} \mathrm{p}<0.10, * * \mathrm{p}<0.05, * * * \mathrm{p}<0.01$. 
APPENDIX 6 TABLE 1:

HETEROGENEITY BY ABSOLUTE SISBEN SCORE: RISK PROTECTION AND PORTFOLIO CHOICE

\begin{tabular}{|c|c|c|c|c|c|c|}
\hline \multicolumn{7}{|l|}{ Panel A: Risk Protection } \\
\hline Outcome: & $\begin{array}{c}\text { Individual } \\
\text { Inpatient } \\
\text { Medical } \\
\text { Spending }\end{array}$ & $\begin{array}{c}\text { Individual } \\
\text { Outpatient } \\
\text { Medical } \\
\text { Spending }\end{array}$ & $\begin{array}{c}\text { Variability of } \\
\text { Individual } \\
\text { Inpatient } \\
\text { Medical } \\
\text { Spending }\end{array}$ & $\begin{array}{c}\text { Variability of } \\
\text { Individual } \\
\text { Outpatient } \\
\text { Medical } \\
\text { Spending }\end{array}$ & & \\
\hline Enrolled Subsidiado & $\begin{array}{c}-14,444 \\
{[186,361]}\end{array}$ & $\begin{array}{l}-12,516 \\
{[21,894]}\end{array}$ & $\begin{array}{c}-20,924.11 \\
{[183,706]}\end{array}$ & $\begin{array}{c}-16,609.78 \\
{[19,330]}\end{array}$ & & \\
\hline (Enrolled Subsidiado)*SISBEN & $\begin{array}{c}-989 \\
{[4,137]}\end{array}$ & $\begin{array}{c}358 \\
{[518]}\end{array}$ & $\begin{array}{c}-1,036.95 \\
{[4,069]}\end{array}$ & $\begin{array}{c}373.37 \\
{[458]}\end{array}$ & & \\
\hline SISBEN & $\begin{array}{c}2,265 \\
{[1,989]}\end{array}$ & $\begin{array}{c}-555.27 * * \\
{[262]}\end{array}$ & $\begin{array}{c}2,318.25 \\
{[1,951]}\end{array}$ & $\begin{array}{c}-524.03 * * \\
{[232]}\end{array}$ & & \\
\hline SISBEN_diff & $\begin{array}{c}-5,029.91 \\
{[3,217]}\end{array}$ & $\begin{array}{l}629.25 \\
{[315]}\end{array}$ & $\begin{array}{c}-5,074.36 \\
{[3,218]}\end{array}$ & $\begin{array}{c}650.77 * * \\
{[276]}\end{array}$ & & \\
\hline Effect of being enrolled in subsidiado at score 45 & $-58953 *$ & 3,585 & $-67586.74 * *$ & 191.89 & & \\
\hline P-value of hypothesis that the above effect is null & 0.08 & 0.23 & 0.04 & 0.94 & & \\
\hline Observations & 4,219 & 4,218 & 4,219 & 4,218 & & \\
\hline Data Source & $\mathrm{ECV}$ & ECV & ECV & $\mathrm{ECV}$ & & \\
\hline \multicolumn{7}{|l|}{ Panel B: Portfolio Choice } \\
\hline Outcome: & $\begin{array}{c}\text { Individual } \\
\text { Education } \\
\text { Spending } \\
\end{array}$ & $\begin{array}{c}\text { Household } \\
\text { Education } \\
\text { Spending } \\
\end{array}$ & $\begin{array}{c}\text { Total } \\
\text { Spending on } \\
\text { Food }\end{array}$ & $\begin{array}{c}\text { Total } \\
\text { Monthly } \\
\text { Expenditure } \\
\end{array}$ & Has Car & Has Radio \\
\hline Enrolled Subsidiado & $\begin{array}{c}-2,431 \\
{[23,319]}\end{array}$ & $\begin{array}{c}-273,304^{*} \\
{[162,446]}\end{array}$ & $\begin{array}{c}997,617 \\
{[732,788]}\end{array}$ & $\begin{array}{c}-6778852 \\
{[5,532,992]}\end{array}$ & $\begin{array}{c}0.09 \\
{[0.25]}\end{array}$ & $\begin{array}{c}0.89 \\
{[1.28]}\end{array}$ \\
\hline (Enrolled Subsidiado)*SISBEN & $\begin{array}{c}46 \\
{[593]}\end{array}$ & $\begin{array}{l}6,759^{*} \\
{[3,952]}\end{array}$ & $\begin{array}{l}-21,423 \\
{[16,055]}\end{array}$ & $\begin{array}{c}147,659 \\
{[123,948]}\end{array}$ & $\begin{array}{l}-0.00 \\
{[0.01]}\end{array}$ & $\begin{array}{l}-0.02 \\
{[0.03]}\end{array}$ \\
\hline SISBEN & $\begin{array}{c}255 \\
{[361]}\end{array}$ & $\begin{array}{l}-2,786 \\
{[2,043]}\end{array}$ & $\begin{array}{c}3,117 \\
{[6,940]}\end{array}$ & $\begin{array}{c}-239,413 * * * \\
{[64,369]}\end{array}$ & $\begin{array}{l}-0.00 \\
{[0.00]}\end{array}$ & $\begin{array}{l}-0.01 \\
{[0.01]}\end{array}$ \\
\hline SISBEN_diff & $\begin{array}{l}-311 \\
{[299]}\end{array}$ & $\begin{array}{c}1,670 \\
{[1,490]}\end{array}$ & $\begin{array}{c}14,831 \\
{[13,758]}\end{array}$ & $\begin{array}{c}193,184 * * * \\
{[40,664]}\end{array}$ & $\begin{array}{c}0.01 \\
{[0.01]}\end{array}$ & $\begin{array}{c}0.05^{* * *} \\
{[0.01]}\end{array}$ \\
\hline Effect of being enrolled in subsidiado at score 45 & -347 & 30833 & 33589 & -134205 & 0.02 & $0.19 *$ \\
\hline P-value of hypothesis that the above effect is null & 0.92 & 0.12 & 0.75 & 0.68 & 0.60 & 0.08 \\
\hline Observations & 3,567 & 4,222 & 4,096 & 966 & 3,334 & 3,334 \\
\hline Data Source & $\mathrm{ECV}$ & $\mathrm{ECV}$ & $\mathrm{ECV}$ & $\mathrm{ECV}$ & DHS & DHS \\
\hline \multicolumn{7}{|c|}{$\begin{array}{l}\text { Individual-level "urban" data for those within two SISBEN index points of county-specific eligibility thresholds from the } 2003 \text { ECV and } 2005 \\
\text { DHS. Dependent variables are shown at the top of each column. The first two rows shows } 2 \text { SLS estimates for enrollment in the Subsidized } \\
\text { Regime (SR) and its interaction with simulated SISBEN score, instrumenting both using simulated eligibility and its interaction with simulated } \\
\text { SISBEN score. The third row shows the coefficient associated with simulated SISBEN score, and the fourth row shows the coefficient associated } \\
\text { with distance from the the county-specific threshold. The fifth row shows the effect of being enrolled in SR for those with a SISBEN score of } 45 \text {, } \\
\text { computed as the coefficient associated with Enrolled Subsidiado -first row- summed to the multiplication of } 45 \text { with the coefficient associated } \\
\text { with (Enrolled Subsidiado)*SISBEN -second row- The sixth row shows the P-value that this effect is null. The seventh row shows the number of } \\
\text { observations. All specifications include estrato dummy variables, and county fixed effects. Standard errors (clustered by county) are shown in } \\
\text { brackets below each estimate. } * \mathrm{p}<0.10, * * p<0.05, * * * p<0.01 \text {. }\end{array}$} \\
\hline
\end{tabular}


APPENDIX 6 TABLE 2:

HETEROGENEITY BY ABSOLUTE SISBEN SCORE: USE OF PREVENTIVE MEDICAL CARE AND HEALTH STATUS

\begin{tabular}{|c|c|c|c|c|c|c|}
\hline & \multicolumn{2}{|c|}{ Use of Preventive Care } & \multicolumn{4}{|c|}{ "Health Status (Children) } \\
\hline Outcome: & $\begin{array}{c}\text { Preventive } \\
\text { Physician } \\
\text { Visit }\end{array}$ & $\begin{array}{c}\text { Number of } \\
\text { Growth Dev. } \\
\text { Checks Last } \\
\text { Year }\end{array}$ & $\begin{array}{l}\text { Child Days } \\
\text { Lost to Illness }\end{array}$ & $\begin{array}{l}\text { Cough, } \\
\text { Fever, } \\
\text { Diarrhea }\end{array}$ & $\begin{array}{c}\text { Any Health } \\
\text { Problem }\end{array}$ & $\begin{array}{c}\text { Birthweight } \\
\text { (KG) }\end{array}$ \\
\hline Enrolled Subsidiado & $\begin{array}{c}0.72 \\
{[0.82]}\end{array}$ & $\begin{array}{c}6.47 \\
{[5.41]}\end{array}$ & $\begin{array}{c}4.59 \\
{[4.47]}\end{array}$ & $\begin{array}{l}-0.38 \\
{[2.03]}\end{array}$ & $\begin{array}{c}0.27 \\
{[1.63]}\end{array}$ & $\begin{array}{l}-1.43 \\
{[2.25]}\end{array}$ \\
\hline$($ Enrolled Subsidiado)*SISBEN & $\begin{array}{l}-0.01 \\
{[0.02]}\end{array}$ & $\begin{array}{l}-0.11 \\
{[0.12]}\end{array}$ & $\begin{array}{l}-0.13 \\
{[0.10]}\end{array}$ & $\begin{array}{c}0.00 \\
{[0.04]}\end{array}$ & $\begin{array}{l}-0.01 \\
{[0.04]}\end{array}$ & $\begin{array}{c}0.04 \\
{[0.05]}\end{array}$ \\
\hline SISBEN & $\begin{array}{c}-0.02 * * \\
{[0.01]}\end{array}$ & $\begin{array}{l}-0.02 \\
{[0.06]}\end{array}$ & $\begin{array}{c}0.08 \\
{[0.05]}\end{array}$ & $\begin{array}{c}0.01 \\
{[0.01]}\end{array}$ & $\begin{array}{c}0.00 \\
{[0.01]}\end{array}$ & $\begin{array}{c}-0.11 * * * \\
{[0.04]}\end{array}$ \\
\hline SISBEN_diff & $\begin{array}{c}0.06^{* * * *} \\
{[0.01]}\end{array}$ & $\begin{array}{c}0.07 \\
{[0.11]}\end{array}$ & $\begin{array}{l}-0.04 \\
{[0.09]}\end{array}$ & $\begin{array}{l}-0.02 \\
{[0.03]}\end{array}$ & $\begin{array}{c}0.00 \\
{[0.02]}\end{array}$ & $\begin{array}{c}0.13 * * * \\
{[0.05]}\end{array}$ \\
\hline Effect of being enrolled in subsidiado at score 45 & $0.29 * * *$ & $1.66^{* * *}$ & $-1.21 * *$ & -0.19 & -0.05 & 0.20 \\
\hline $\mathrm{P}$-value of hypothesis that the above effect is null & 0.01 & 0.01 & 0.05 & 0.27 & 0.74 & 0.46 \\
\hline Observations & 4,222 & 1,167 & 1,161 & 1,167 & 1,161 & 897 \\
\hline Data Source & $\mathrm{ECV}$ & DHS & DHS & DHS & DHS & DHS \\
\hline
\end{tabular}

Individual-level "urban" data for those within two SISBEN index points of county-specific eligibility thresholds from the 2003 ECV and 2005 DHS. Dependent variables are shown at the top of each column. The first two rows shows 2SLS estimates for enrollment in the Subsidized Regime (SR) and its interaction with simulated SISBEN score, instrumenting both using simulated eligibility and its interaction with simulated SISBEN score. The third row shows the coefficient associated with simulated SISBEN score, and the fourth row shows the coefficient associated with distance from the the county-specific threshold. The fifth row shows the effect of being enrolled in SR for those with a SISBEN score of 45, computed as the coefficient associated with Enrolled Subsidiado -first row- summed to the multiplication of 45 with the coefficient associated with (Enrolled Subsidiado)*SISBEN -second row- The sixth row shows the P-value that this effect is null. The seventh row shows the number of observations. All specifications include estrato dummy variables, and county fixed effects. Standard errors (clustered by county) are shown in brackets below each estimate. $* \mathrm{p}<0.10, * * \mathrm{p}<0.05, * * * \mathrm{p}<0.01$ 


\begin{tabular}{|c|c|c|c|c|}
\hline Outcome: & $\begin{array}{l}\text { Curative Use } \\
\text { (Not } \\
\text { Conditonal on } \\
\text { Health Status) }\end{array}$ & $\begin{array}{l}\text { Curative Use } \\
\text { among } \\
\text { Children (Not } \\
\text { Conditional } \\
\text { on Health } \\
\text { Status) }\end{array}$ & $\begin{array}{l}\text { Medical Visit } \\
\text { for Chronic } \\
\text { Disease }\end{array}$ & Hospital Stay \\
\hline Enrolled Subsidiado & $\begin{array}{c}-0.46 \\
{[0.45]}\end{array}$ & $\begin{array}{c}1.07 \\
{[1.45]}\end{array}$ & $\begin{array}{l}2.67 * \\
{[1.39]}\end{array}$ & $\begin{array}{c}0.44 \\
{[0.68]}\end{array}$ \\
\hline (Enrolled Subsidiado)*SISBEN & $\begin{array}{c}0.01 \\
{[0.01]}\end{array}$ & $\begin{array}{c}-0.02 \\
{[0.03]}\end{array}$ & $\begin{array}{c}-0.05 \\
{[0.03]}\end{array}$ & $\begin{array}{c}-0.01 \\
{[0.02]}\end{array}$ \\
\hline SISBEN & $\begin{array}{c}-0.01 * * \\
{[0.01]}\end{array}$ & $\begin{array}{c}0.05^{* * * *} \\
{[0.01]}\end{array}$ & $\begin{array}{c}0.12 * * * * \\
{[0.03]}\end{array}$ & $\begin{array}{c}0.00 \\
{[0.01]}\end{array}$ \\
\hline SISBEN_diff & $\begin{array}{c}0.01 \\
{[0.01]}\end{array}$ & $\begin{array}{l}-0.04^{*} \\
{[0.02]}\end{array}$ & $\begin{array}{c}-0.06^{* *} \\
{[0.03]}\end{array}$ & $\begin{array}{c}0.00 \\
{[0.01]}\end{array}$ \\
\hline Effect of being enrolled in subsidiado at score 45 & $0.13 * *$ & 0.03 & $0.64 * * *$ & -0.04 \\
\hline P-value of hypothesis that the above effect is null & 0.035 & 0.85 & 0.01 & 0.70 \\
\hline Observations & 4,222 & 1,161 & 564 & 4,222 \\
\hline Data Source & ECV & DHS & ECV & ECV \\
\hline
\end{tabular}

$\overline{\text { Individual-level "urban" data for those within two SISBEN index points of county-specific eligibility thresholds }}$ from the $2003 \mathrm{ECV}$ and 2005 DHS. Dependent variables are shown at the top of each column. The first two rows shows 2SLS estimates for enrollment in the Subsidized Regime (SR) and its interaction with simulated SISBEN score, instrumenting both using simulated eligibility and its interaction with simulated SISBEN score. The third row shows the coefficient associated with simulated SISBEN score, and the fourth row shows the coefficient associated with distance from the the county-specific threshold. The fifth row shows the effect of being enrolled in SR for those with a SISBEN score of 45, computed as the coefficient associated with Enrolled Subsidiado -first row- summed to the multiplication of 45 with the coefficient associated with (Enrolled Subsidiado)*SISBEN second row- The sixth row shows the P-value that this effect is null. The seventh row shows the number of observations. All specifications include estrato dummy variables, and county fixed effects. Standard errors (clustered by county) are shown in brackets below each estimate. ${ }^{*} \mathrm{p}<0.10,{ }^{* *} \mathrm{p}<0.05,{ }^{* * *} \mathrm{p}<0.01$. 
APPENDIX 6 TABLE 4:

HETEROGENEITY BY ABSOLUTE SISBEN SCORE: BEHAVIORAL DISTORTIONS EX ANTE MORAL HAZARD

\begin{tabular}{|c|c|c|c|}
\hline \multirow[b]{2}{*}{ Outcome: } & \multicolumn{3}{|c|}{ Ex-Ante Moral Hazard } \\
\hline & $\begin{array}{c}\text { Drank } \\
\text { Alcohol } \\
\text { during } \\
\text { Pregnancy }\end{array}$ & $\begin{array}{c}\text { Months } \\
\text { Breastfed as } \\
\text { Child }\end{array}$ & $\begin{array}{l}\text { Folic Acid } \\
\text { During } \\
\text { Pregnancy }\end{array}$ \\
\hline Enrolled Subsidiado & $\begin{array}{l}-0.22 \\
{[0.92]}\end{array}$ & $\begin{array}{c}47.45 \\
{[35.54]}\end{array}$ & $\begin{array}{l}-1.00 \\
{[1.75]}\end{array}$ \\
\hline (Enrolled Subsidiado)*SISBEN & $\begin{array}{c}0.00 \\
{[0.02]}\end{array}$ & $\begin{array}{c}-1.04 \\
{[0.79]}\end{array}$ & $\begin{array}{c}0.02 \\
{[0.04]}\end{array}$ \\
\hline SISBEN & $\begin{array}{c}-0.00^{* *} \\
{[0.00]}\end{array}$ & $\begin{array}{c}0.57 \\
{[0.38]}\end{array}$ & $\begin{array}{c}0.05 * * * \\
{[0.00]}\end{array}$ \\
\hline SISBEN_diff & $\begin{array}{l}-0.02 \\
{[0.02]}\end{array}$ & $\begin{array}{l}-0.30 \\
{[0.70]}\end{array}$ & $\begin{array}{c}-0.06^{* *} \\
{[0.03]}\end{array}$ \\
\hline $\begin{array}{l}\text { Effect of being enrolled in subsidiado at score } 45 \\
\text { P-value of hypothesis that the above effect is null }\end{array}$ & $\begin{array}{r}-0.11 \\
031\end{array}$ & $\begin{array}{l}0.87 \\
0.87\end{array}$ & $\begin{array}{l}0.07 \\
0.68\end{array}$ \\
\hline Observations & 998 & 946 & 988 \\
\hline Data Source & DHS & DHS & DHS \\
\hline $\begin{array}{l}\text { Individual-level "urban" data for those within } \\
\text { eligibility thresholds from the } 2003 \mathrm{ECV} \text { and } 20 \\
\text { top of each column. The first two rows shows } \\
\text { Regime (SR) and its interaction with simulated S } \\
\text { eligibility and its interaction with simulated SIS } \\
\text { associated with simulated SISBEN score, and the } \\
\text { distance from the the county-specific threshold. T } \\
\text { SR for those with a SISBEN score of } 45 \text {, comp } \\
\text { Subsidiado -first row- summed to the multiplic } \\
\text { (Enrolled Subsidiado) } * \text { SISBEN -second row- Th } \\
\text { null. The seventh row shows the number of obser } \\
\text { variables, and county fixed effects. Standard er } \\
\text { below each estimate. } * \mathrm{p}<0.10, * * \mathrm{p}<0.05, * * * \mathrm{p}<0\end{array}$ & $\begin{array}{l}\text { SISBEN in } \\
\text { HS. Depend } \\
\text { estimates fo } \\
\text { s score, instr } \\
\text { score. The tl } \\
\text { h row shows } \\
\text { th row show: } \\
\text { as the coeffi } \\
\text { of } 45 \text { with t } \\
\text { h row shows } \\
\text { is. All specif } \\
\text { clustered by }\end{array}$ & $\begin{array}{l}\text { ex points of } \\
\text { nt variables ar } \\
\text { enrollment in } \\
\text { menting both } \\
\text { rd row shows } \\
\text { he coefficient } \\
\text { the effect of bo } \\
\text { ient associated } \\
\text { e coefficient } \\
\text { the P-value th } \\
\text { ations include } \\
\text { ounty) are sho }\end{array}$ & $\begin{array}{l}\text { ounty-specific } \\
\text { shown at the } \\
\text { he Subsidized } \\
\text { sing simulated } \\
\text { the coefficient } \\
\text { ssociated with } \\
\text { ing enrolled in } \\
\text { with Enrolled } \\
\text { sociated with } \\
\text { t this effect is } \\
\text { strato dummy } \\
\text { vn in brackets }\end{array}$ \\
\hline
\end{tabular}

